\title{
الممارسات غير الآمنة فى مجالى الإنتاج الحيوانى والاجنى بريف محافظة المنوفية

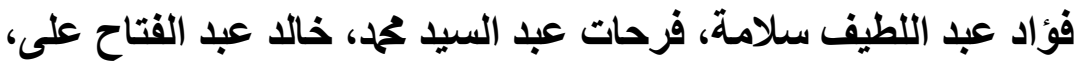

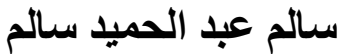 قسم الارشاد الزراعى و المجتمع الريفى ـ كلية الزراعةـ جامعة المنوفية ـ شبين الكوم ـ مصر
}

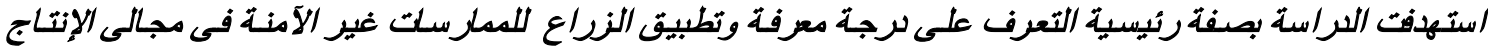

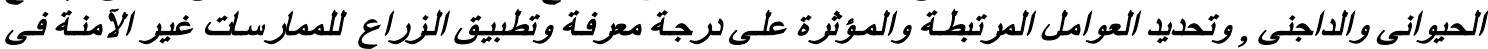

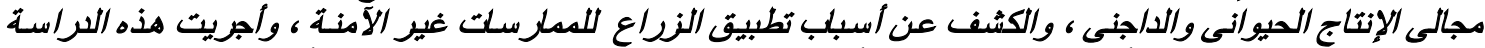

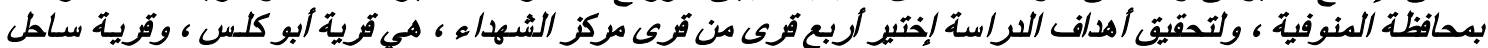

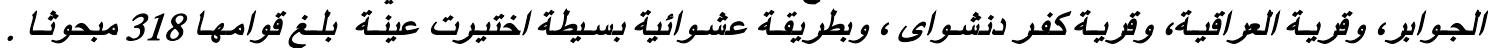

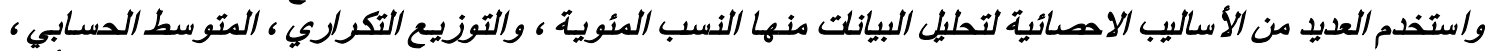

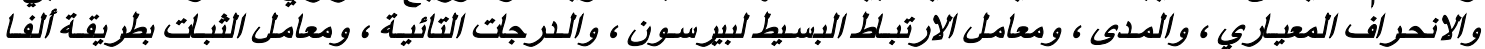

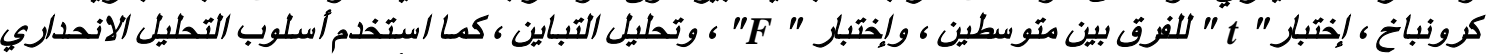

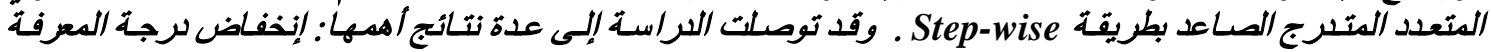

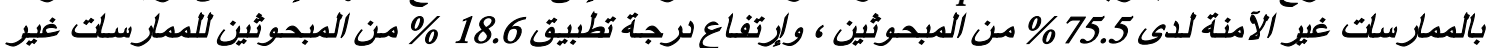

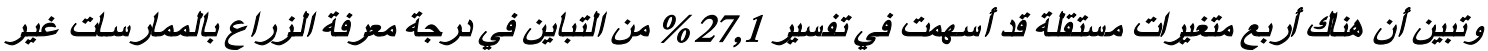

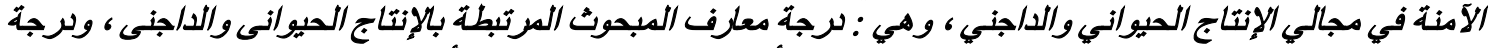

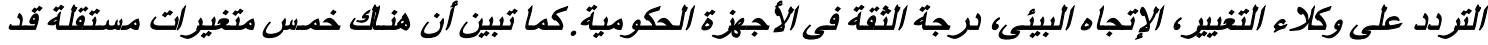

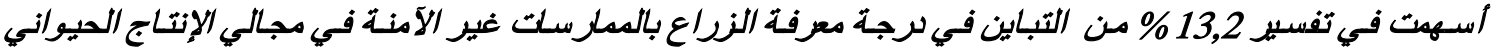

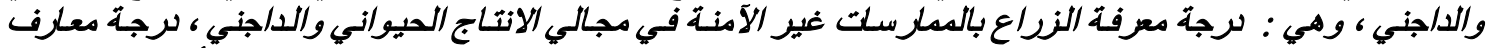
المبحوث الهرتبطة بالإنتاج الحيوانى والداجنى ، الإتجاه البيئى ، الرضاً المجتمعى المحلى ، ومستوى تعليم أسرة المبحوثي.

الكيماويات الزراعية والبيطريـة فى الأغراض المسموح

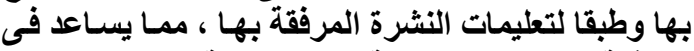

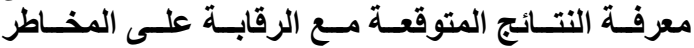

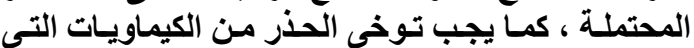

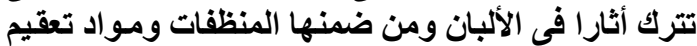

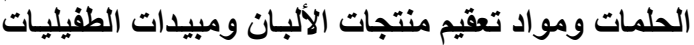

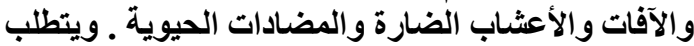

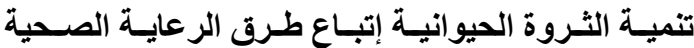

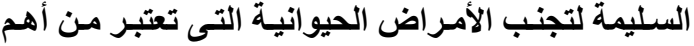

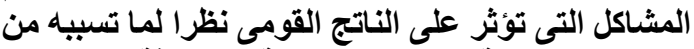

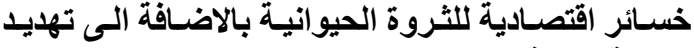

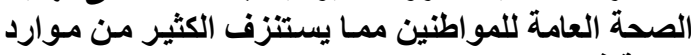
الدولة فى مواجهتها ( إمبارك ومعوض العون ، 2014 : 106 نقلا عن جلال).

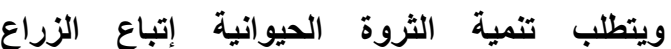

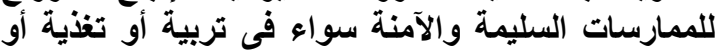

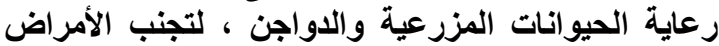

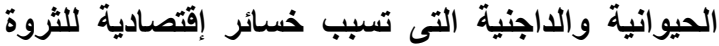

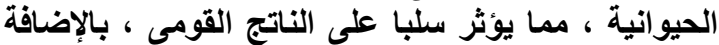

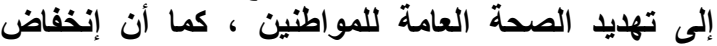

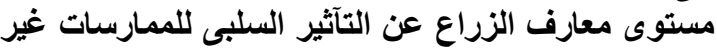
الآمنة وإتجاهاتهم غير الأفير الموالية للبيئة يؤدى إلى إلى إنتثار

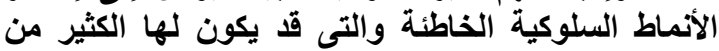

المقدمة والمشكلة البحثية

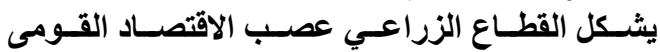

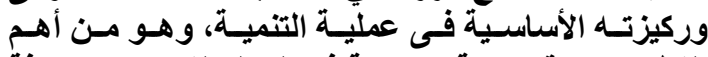

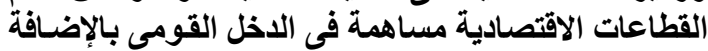

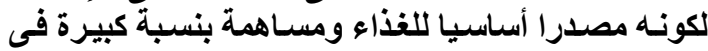

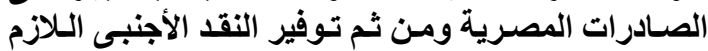

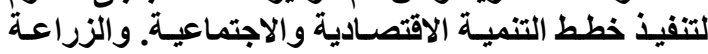

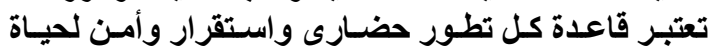

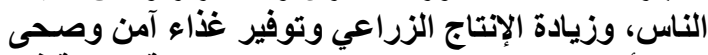

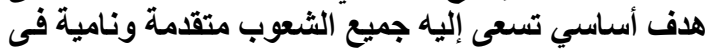

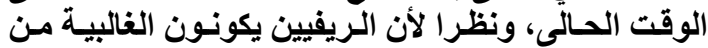

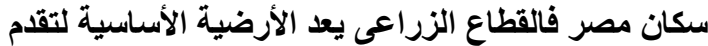
وتغير المجتمع الريفى المصرى (سويلم وآخرون ، 1992

وتثير المنظمة العربية للتنمية الزراعية (2007: 7)

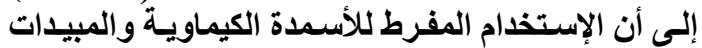

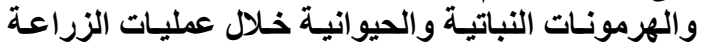

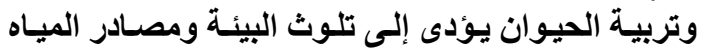

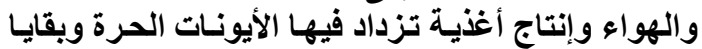

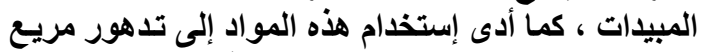

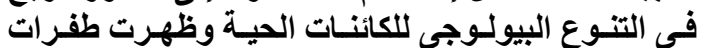

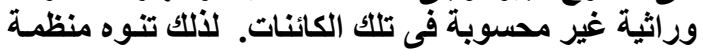
الأغذيـة والزراعـة (15: 2012) على ضـرورة إسـتخدام 
التطوعية، درجة الثقة فى الأجهزة الحكومية ، درجة

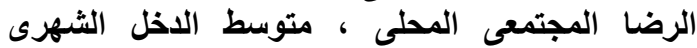

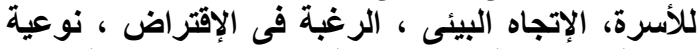

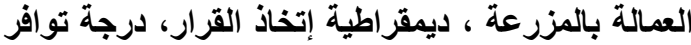

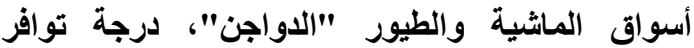
مستلزمات الإنتاج الحيوانى والداجنى ، الطيور لدرجة الإنفتاح

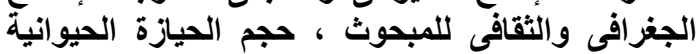

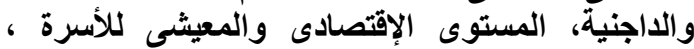

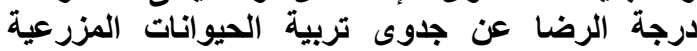

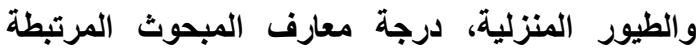
بالإنتاج الحيوانى و الاجاجنى.

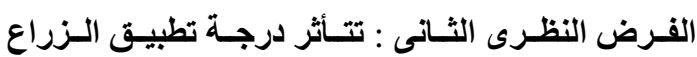

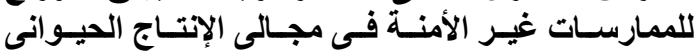

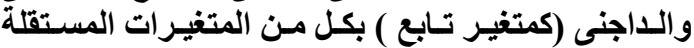

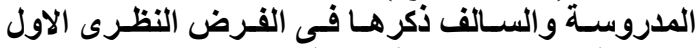

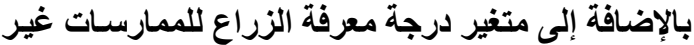

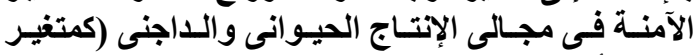
مستقل أيضا).

الاطار النظرى والاستعر اض المرجعى الإزي

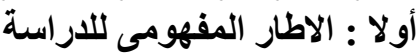

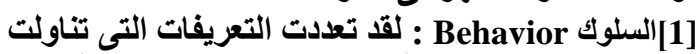
مفهوم السلوك نتيجة لإختلاف ميادين الاراسة، من الإن

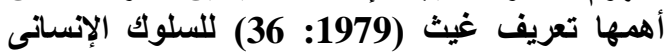

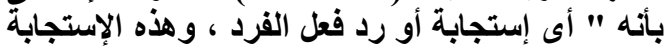

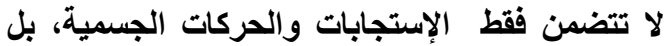
تثمل على الصادرات اللفظية و الخبرات الخبرات الذاتية".

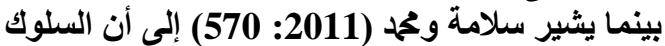
البيئى عبارة عن إستجابة أو رد فعل الفرد تجاه الباه البيئة

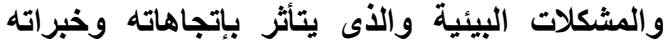
وثقافته وتربيته البيئية.

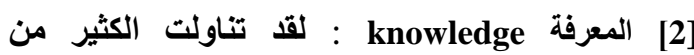
الاراسات المعرفة سواء من حيث مفهومها من زوايا متعددة ومختلفة وإن كانت إتفقت غالبيتها من حيث حيث المضمون ، حيث عرف محرم (1973: 24-24) المعرفة على أنها القدر من المعلومات المن التى يحوزها

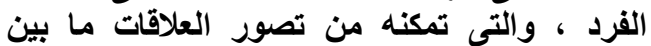

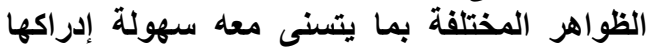
وسرعة إستيعابه. في حين يذكر أبو السعود (1987:

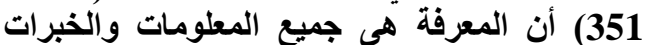

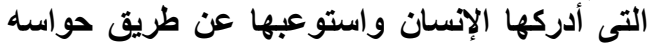

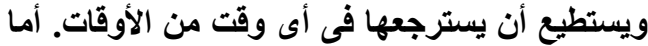

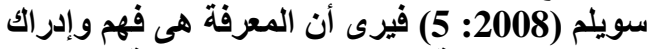
العلاقات والسببية بين مكوناتها المعلوماتية.

[3][الآتجاه Attitude : تباينت آراء العلماء فيما يتطلق

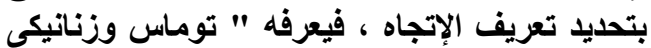

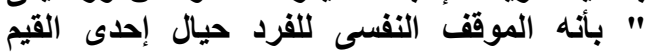

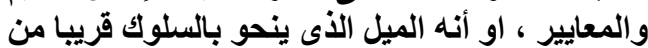
بعض عوامل البيئة أو يبعده عنها ، ويضفى الئل عليها
الآثار الضارة على البيئة بثكل عام وعلى الإنسان بثكل

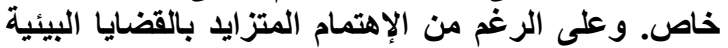

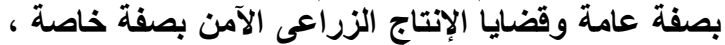

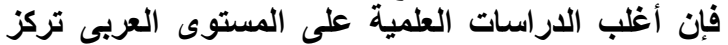

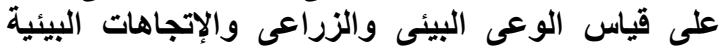

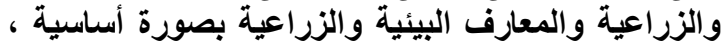

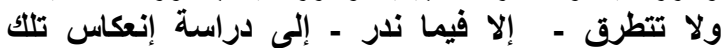

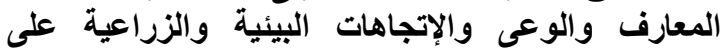
الإستعداد والنية للعمل من أجل البيئة والسلوكيات البئية البيئية

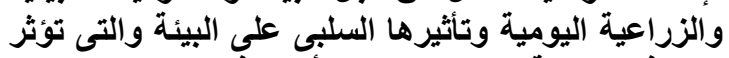

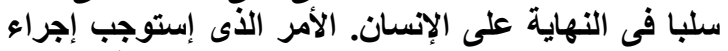

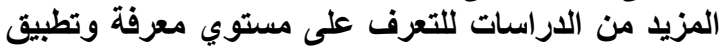

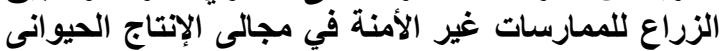

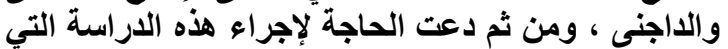

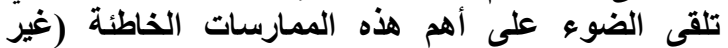

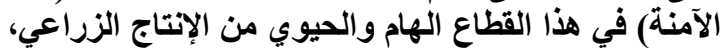

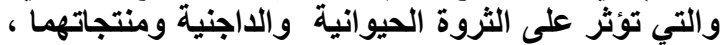
وبالتبعية تؤثر في النهاية على صحة الإنسان .

أهداف الدراسة : تستهدف هذه الدراسة بصفة رئيسية

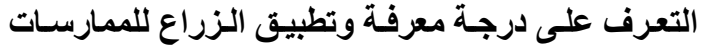

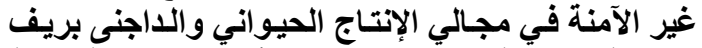
محافظة المنوفية من خلال تحقيق الأهدافت الفرعية الآتية 1. التعرف على مستوى معرفة الزراع للممارسـات غير

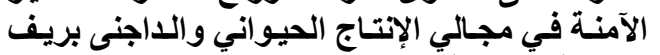
محافظة المنوفية .

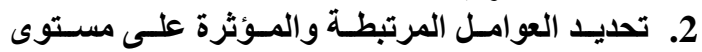

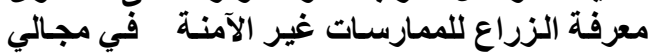
الإنتاج الحيواني والداجنى.

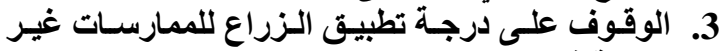

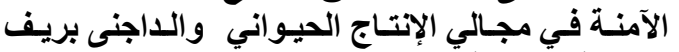
محافظة المنوفية.

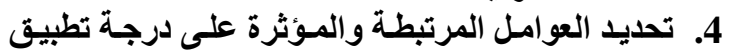

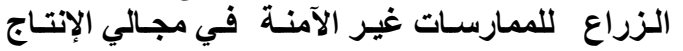

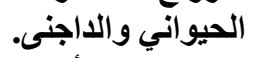

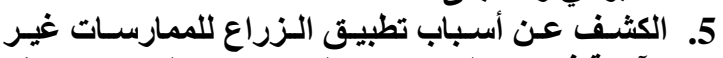

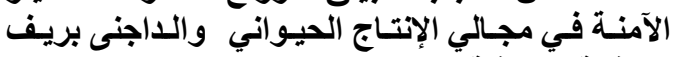

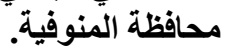

فـروض الدراسـة : لتحقيق الهـف الثـانى والرابـع مـن أهداف الدراسة تم صياغة الفروض الترف التالية :

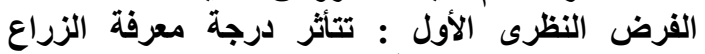

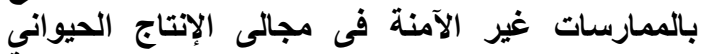

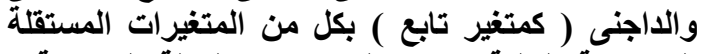

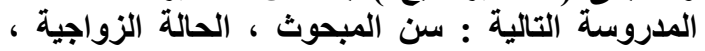

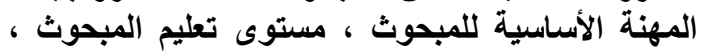

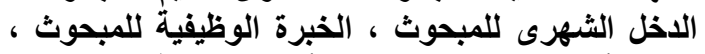

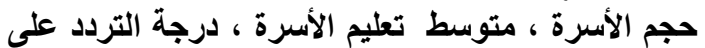
وكلاء التغيير ، درجة التردد على على المراكز الخدمية ، إتجاه المبحوث نحو التجديدية ، إتجاه المبحوث نحو المراكئ الثشاركة 
وآخرون(1973: 225)، وعبد الغفار(1976: 1976: 331) (1978,p: 46)Mosherg ,

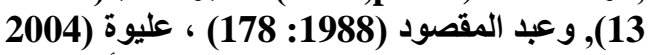
290:

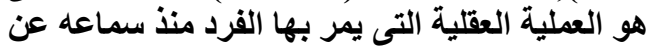

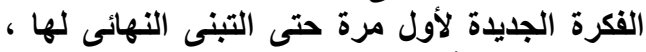

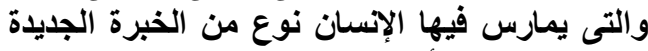

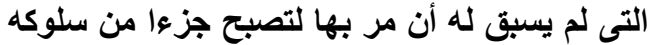

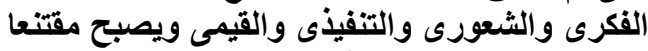
بها, وبذلك تعتبر عملية التبنى مزيج من عمليتى ولفئى التعلم وإتخاذ القرارات .

[6] عواقب المستحدثات [ Consequences of (2003,p: 149) Rogers يعرف :Innovations عواقب المستحدثات بأنها التغيرات التى تحدث لفرد

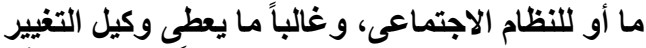

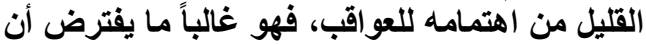

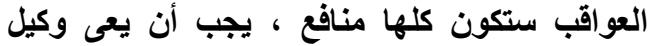
التغيير بكل المميزات والعيوب وتعريف عملائه بها.

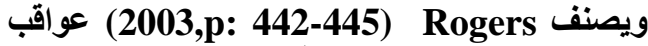

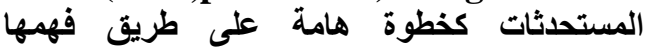
واستيعابها في ثلاث ثنائيات متقابلة وفئاً لثثلاثة أبعاد

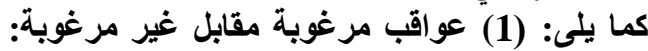

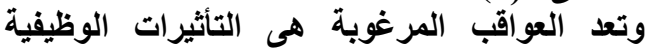

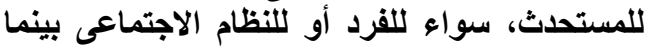

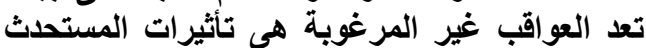

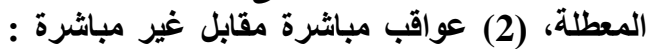

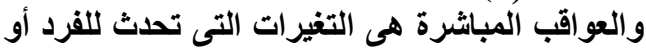

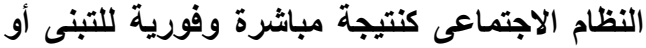

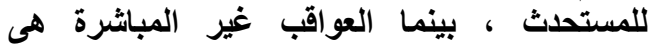
التغيرات التى تحدث كنتيجة للعواقب المباشثرة

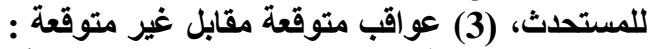

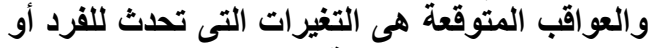

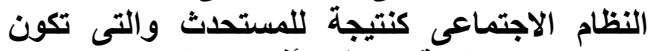

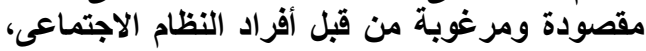

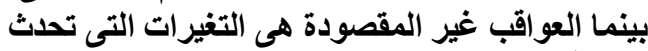
كنتيجة للمستحدث وتكون غير مقصودة ولئيت

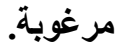

ثانياً : الإطار النظرى للاراسة : تمثل سلوكيات الإنسان أهم الأسباب الرئيسية فى حدوث الإنيان المشكلات

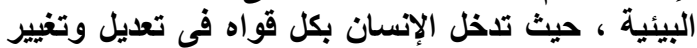

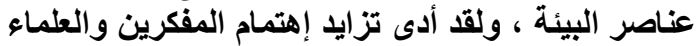

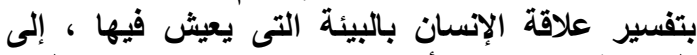

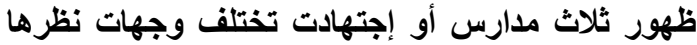

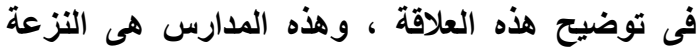

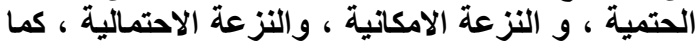

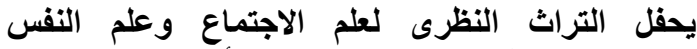

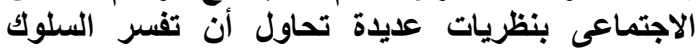

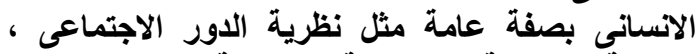
ونظرية المقايضة الاجتماعية ، ونظرية الفعل الاجتماعى الأئى
معايير موجبة أو سالبة تبعا لإنجذابه أو نفوره عنها،

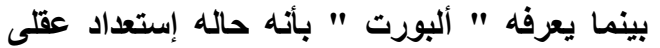

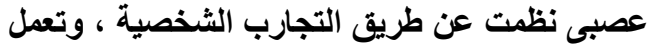

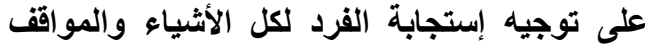

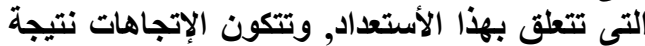

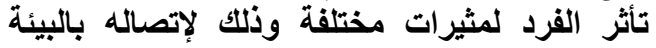

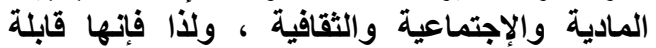
للتغير تبعا لتغير صلة الفرد بتلك المثيرات (حسن ،

1998: 283 - 282

[4] الممارسة Practice : تعرف الممارسة بأنها تكرار

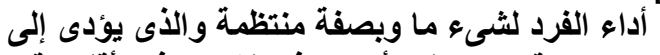

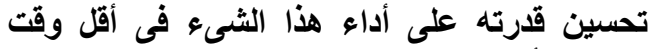
ممكن وبأقل مجهود (الديب ، 2002 ، 2002 : 102 - إيماء فئان

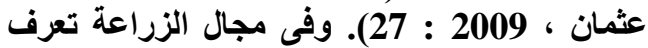
الممارسة بأنها تطبيق الزراع للتوصيات الجديدة

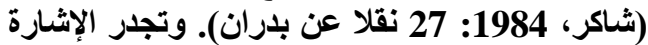

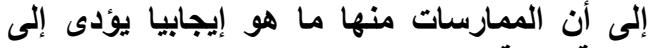

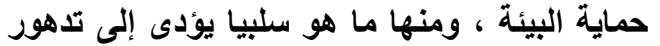

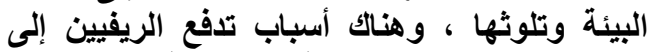

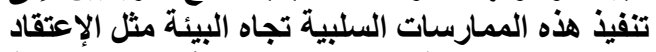

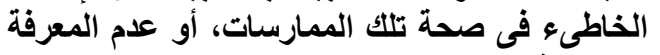

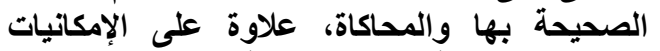

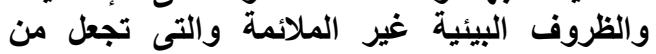

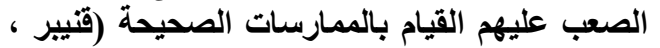
2011 : 419 نقلا عن جاد الرب وزينب عحم).

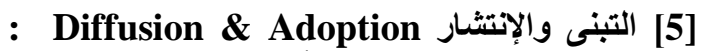
يشير سلامه (1995: 48) أنه وفقا لنتائج البحوث و

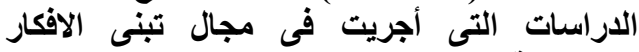
المستحدثة توجد عمليتان مترابطتان ومتاندانتلتان تتعلقان بنقل وتوصيل الأفكار الجديدة من مصادئ ومثادها

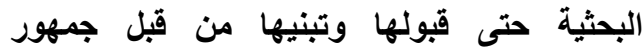

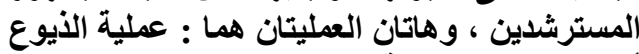

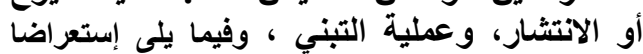
لمفهومى التبنى والإنتشار ، وكنلك المفاهيم المرتبطة بهما:

(أ) عملية الانتشار أو الذيوع Diffusion Process

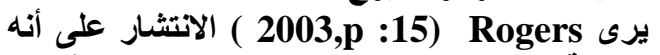
العملية التي يتم من خلالها إرسال مبتكر, عبر قتئوات التهات

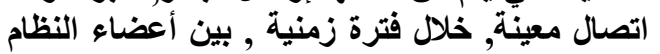

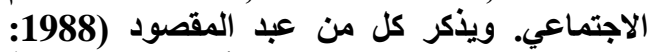
177) ، والثنافعى (2002: 40) أن الن الانتشار عملية إتصال من نوع خاص حيث يهتم بنقل الافكار الجديدة

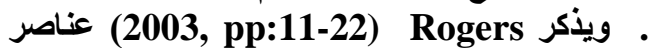
عملية الإنتثار وهى المبتكر-Innovation، وقنوات

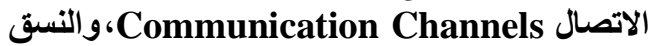
الاجتماعىSocial System، وأخيرا الزمن Time.

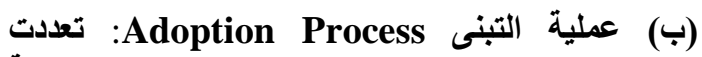
التعاريف التى تناولت مفهوم التبنى ، ويمراجعة تعريف كل من روجرز (1962: 155)، وعمر 
ثالثاً: الاراسات السابقة: بمراجعة الاراسات والبحوث

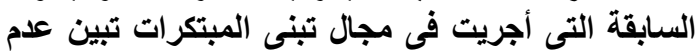

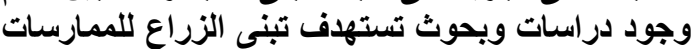

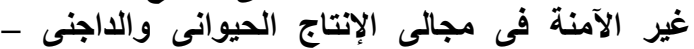

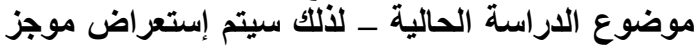

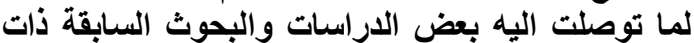

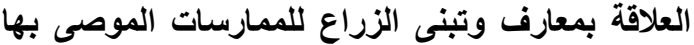

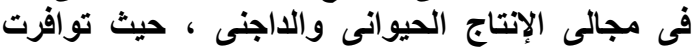
للمراجعة (35) بحثا ودراسة ، أمكن تصنيفها إلى أربي تصنيفات وفقا لوحدات البحث ، وهئ ، ولئ :

الاراسات والبحوث التى تناولت معرفة الزراع

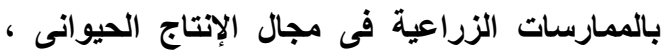

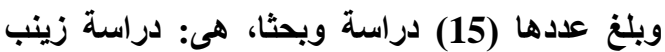

على (1996) ، وجاد الرب وشلبى (1997) ،

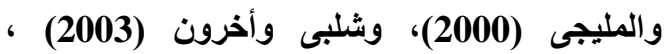

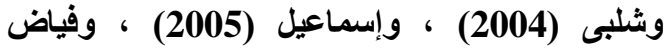
، (2010)، ورمضان (2012)، وحسنين (2012) وإبتسام المليجى (2012) ، وآمال الديب ومرفت

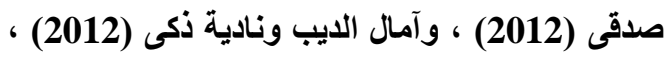
وسامية موسة وأخرون (2013) ، وإمبارك ومعوض (2014) ، وشلبى (2016) ـ وقد تبين من نتائجها: (أ) معظم النتائج الخاصة بمستوى معرفة المربين سواء بالتوصيات الفنية فى مجال تربية ورعاية الحيوان الزراعى أو المتعلقة بالرعاية البيطرية والتناسلية أو الوالية المتعلقة بالأمراض المثتركة بين الإنسان والحيوان وطرق الوقاية منها تنحصر بين مستوى المعرفة المنخفض والمتوسط. (ب) وجود علاقة إرتباطية معنوية موجبة بين درجة المعرفة بالممارسات الزراعية وكل من المتغيرات المستقلة الأتية: مستوى دائة

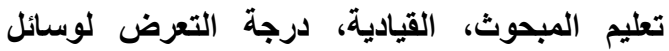

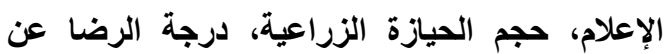

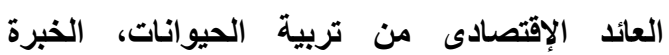

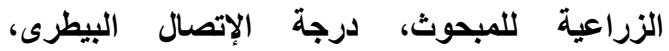
التجديدية، حجم الحيازة الحيوانية، المساحة المنزرعة لإنية

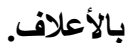

[2] الدراسات والبحوث التى تناولت تطبيق الزراع للممارسات الزراعية فى مجال الإنتاج الحيوانى، ويلغ عددها (9) دراسات وبحث ، هى : دراسة زينب على (1996)، وحسين وأنور (1998)، والمليجى
الإرادى (الغنام،2001: 61) ـ وفيما يلى أهم المداخل

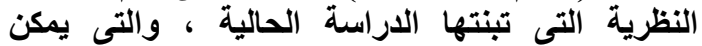

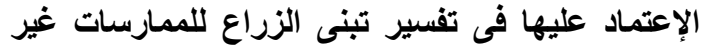

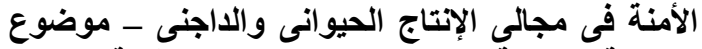

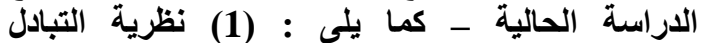
الإجتماعى : ترى هذه النظرية أن الأفراد يدخلون بصفة

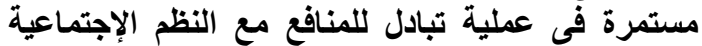

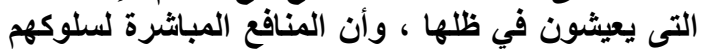

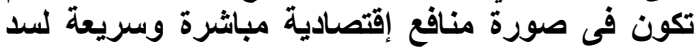

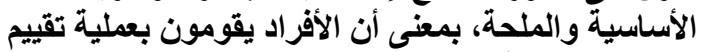

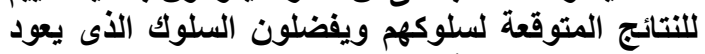
عليهم بعائد مباثر أو ذلك السلوك ولئك الذى يقلل من تكلفتهر

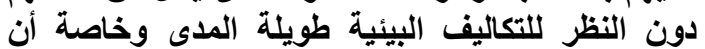
أعباء التذهور الزراعى والبيئى يتحمله المجتمع كلئ، وخلئ

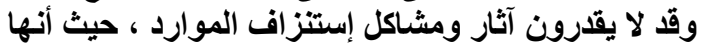

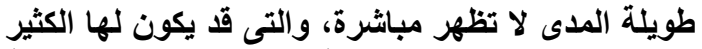

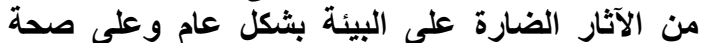

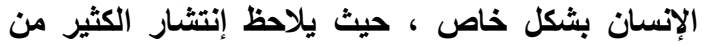
الأمراض والتى أصبحت متوطنة مثل الفثل الفثل الكلوى والكبدى وكذلك الأمراض السرطانية ومشاكل الجهاز

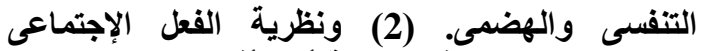
الإرادى: تفترض هذه النظرية أن الأفراد يسعون لتحقيق الإنيق أهداف شخصية في ظل مواقفت وأوضاع الأن معينة يتوفر فيها

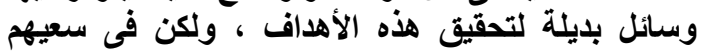

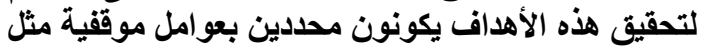

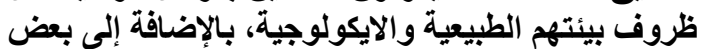

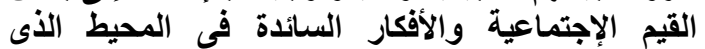

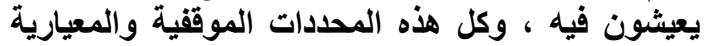
تؤثُ على قدراتهم فى اختيار الوسائل التى يمكن أن تحقّق

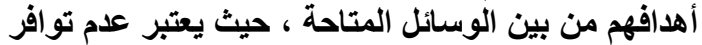

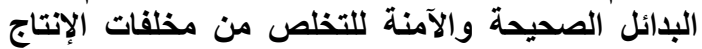

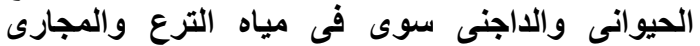

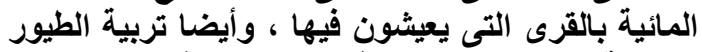

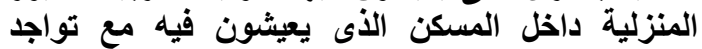

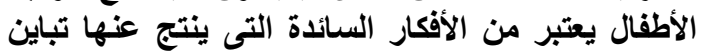
وإختلاف فى السلوك البيئى للزراع ـ (3) نظرية الأنى الدور

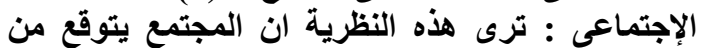

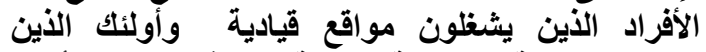

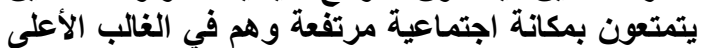

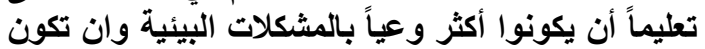

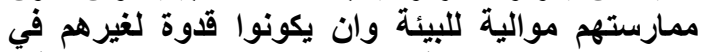

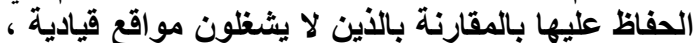

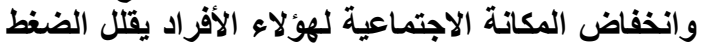

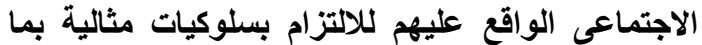

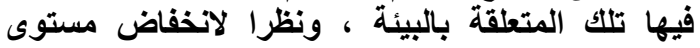

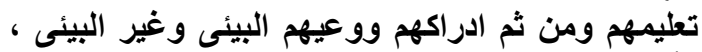

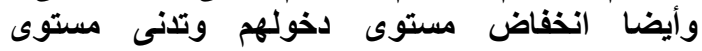

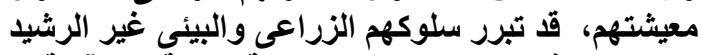
، والمتمثل فى تبنى ممارسات زراعية وبيئية غير آمنة. 
عددها (4) دراسات وبحث ، وهى: دراسة العباسى

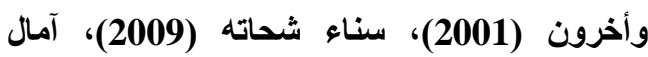
الايب (2011)، رمضان والمليجى (2015)، وتبين من نتائجها: (أ) وجود علاقة إرتباطية موجبة بين درجة تطبيق الممارسات وكل من المتغيرات المستقلة

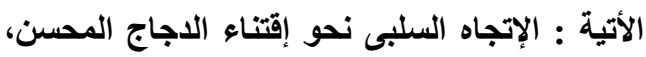
التردد على وكلاء التغيير، سن المبحوث، عداء التئن

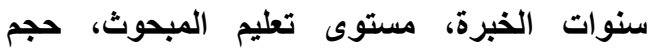

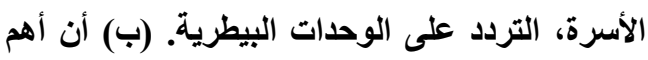

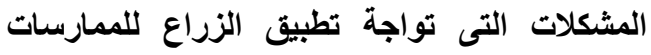
الزراعية فى مجال الإنتاج الداجنى هى: إرتفاع أسعار الأعلاف، عدم توافر مكان مناسب للتربية، كثرة الآناجة

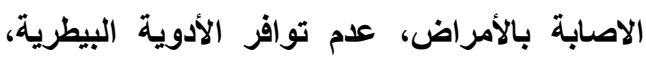
إرتفاع أسعار الأمصال واللقاحات، قلة عدأد المرشدين

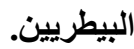

$$
\text { الإجراءات البحثية }
$$

[1] منظقة الدراسة: تمثل محافظة المنوفية الحيز الجغرافى والبشرى لهذه الدراسة، ولإجراء هذهة لهنه الاراسة إختير مركز الثهاء - وتئري وفقا لاليل التنمية البشرية لمحافظة المنوفية 2014.

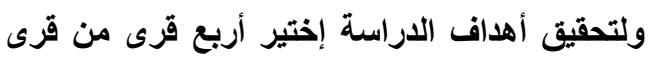
مركز الثهاءه، روعى فى إختيارها تباين مستواها

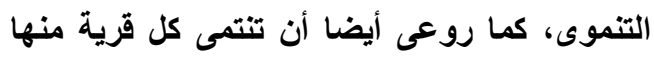

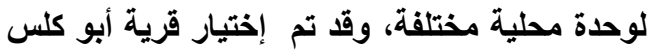
التابعة للوحدة المحلية بلنثواى، وقرية سلحل

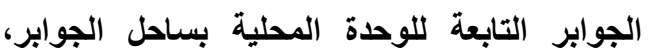

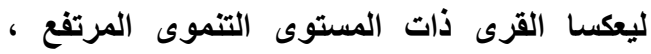

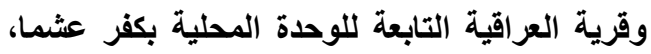
وقرية كفر دنثواى التابعة للوحدة المحلية بزاوية

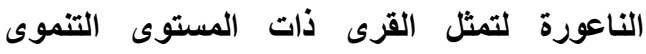
المنخفض وفقا للاليل التتمية البشرية لمحافظة المنوفية 2014 ، والذى يعكس ثلاث مؤشرات

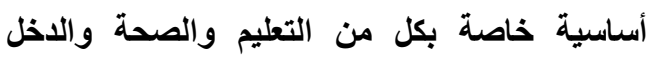
(تقرير التنمية البشرية لمحافظة المنوفية ، 2014).
(2000)، وإسماعيل (2005)، ورمضان (2012)، وآمال الديب ومرفت صدقى (2012) ، وجمعة (2015) ، وندان (2012)

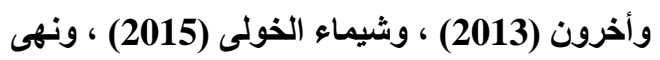

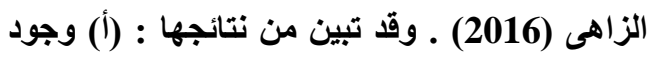
علاقة إرتباطية معنوية موجبة بين درجة التطبيق للممارسات الزراعية وكل من المتغيرات المستقلة الأتية: الإتجاه نحو إستخدام المستحدثات الزراعية، تحصين الحيوانات ضد الأمراض الوبائية، حجم الإنداه الحيازة الزراعية، حجم الحيازة الحيوانية، مستوى الائيات

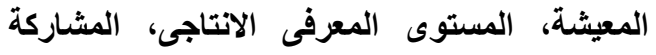

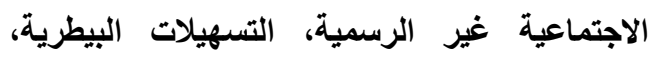
الخبرة الزراعية، مستوى تعليم المبحوث، الإنفتاح

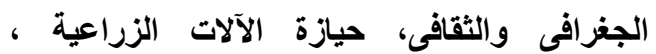

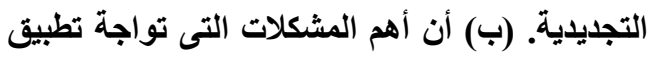

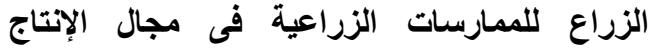

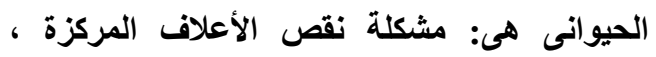

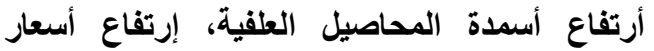

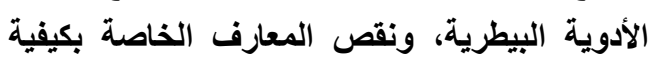
التخلص من الحيوانات النافقة، تدنى المعرفة بأضرار رعى الماثية بجوار الترع والمصارف، تربية الطيور بجوار الحيوانات المزرعية.

[3] الاراسات والبحوث التى تناولت معرفة الزراع

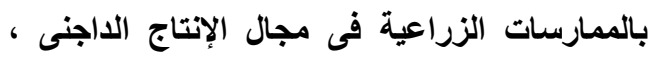

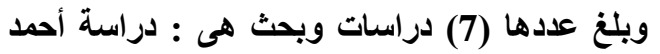

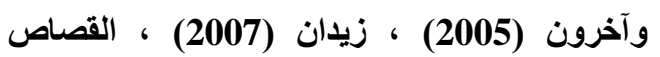
والمسعودى (2008) ،القصاص وآخرون (2011) ، واندان (2011) ،

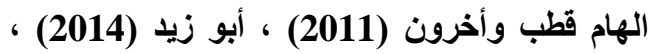
رمضان والمليجى (2015) ـ وقد تبين من نتائجها : (أ) إنخفاض درجة المعرفة بالممارسات الزراعية

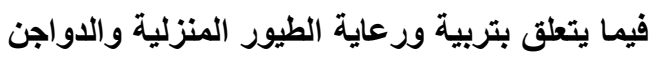
• (ب) وجود علاقة ارتباطية مغنوية موجبة بين درجة معرفة الممارسات وكل من المتغيرات المستقلة الأتية: مستوى تعليم المبحوث، الإتجاه نحو العمل الإرشادى، عدد سنوات الخبرة فى التربية، التجديدية، التعرض لمصادر المطلومات الزراعية .

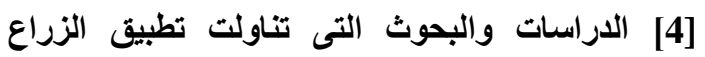

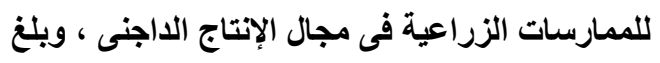


[4] المفاهيم الاجرائية وقياس المتغيرات البحثية : تبين

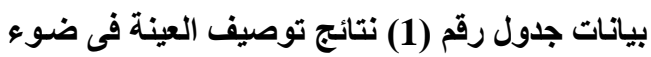

المفاهيم الاجرائية لمتفيرات الدراسة وهى :

$$
\text { أ) : المتغيرات المستقلة }
$$

(1) السن : تم قياسـه بعدد سنوات عمر المبحوث حتى

تاريخ جمع البيانات لأقرب سنة ميلادية.

(2) الحالة الزواجية : وهى تعبر عن الحالة الإجتماعية

التى يكون عليها المبحوث وقت جميع البيانـات ، وتم

قياسها بمقياس إسمى" Nominal " : أعزب = 1 البهان

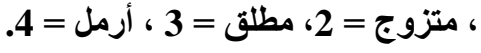

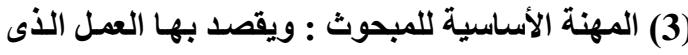

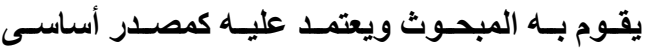

للاخل، وتم قياسها بمقياس إسمى " Nominal " :

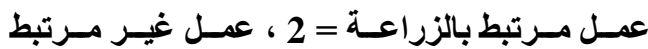

$$
\text { بالزراعة =1 } 1 .
$$

(4) مستوى تعليم المبحوث : تم قياسه كرقم مطلق يعبر

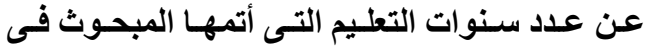

$$
\text { مختلف مراحل التعليم الرسمى. }
$$

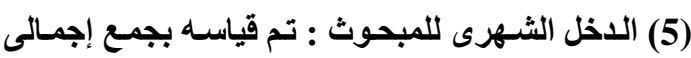

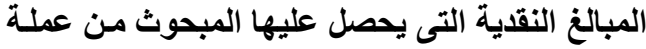
الأصلـى بالاضـافة إلى أى عمـل أخر يقوم بـه خـلال

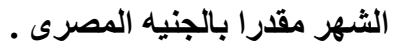

(6) حجم الأسرة : تم قياسـة كرقم مطلق يعبر عن عداد

الأفراد الذين يعيشون مع المبحوث فى وحدة معيشية

$$
\text { واحدة. }
$$

(7) مسـتوى تعلـيم الأسـرة : وتــم قيساس هــا المتغيـر

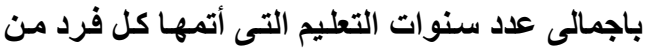

أفراد الأسرة وقسمتها على عدد الأفراد لمن بلغت

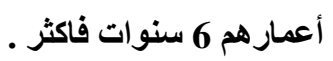

(8) الخبرة الوظيفية للمبحوث: تم قياسه كرقم مطلق

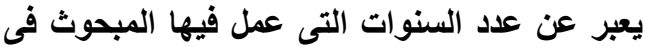
مجال تربية الحيوانات المزرعية والطيور المنزلية،

وإستخدم كمؤشر يعكس خبرته الوظيفية فى هذات

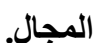

(9) درجـة التردد على وكـلاء التغيير: وهـو يشير إلى التى

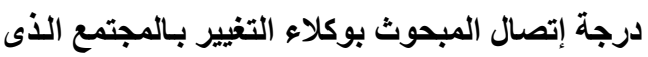

يعيش فيه ، رغبة منـه الى التغيير وتحسين وضعائه
[2] عينة الدراسة: تم اختيار الحجم المناسب لعينة الاراسة بكل قرية من خلال تطبيق معادلة يمانى

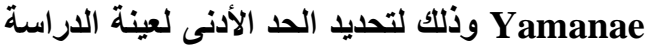
بالقرى المختارة ، وبتطبيق المعادلة السابقة تبين أن حجم العينة الكلى 318 مبحوثا منهم 66 مبحوثا بقرية أبو كلس ، و 120 مبحوثا بقرية ساحل الجو ابر

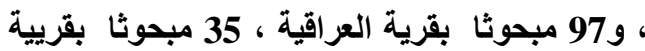
كفر دنثواى ، وتم إختيار العينات بطريقة عشوائية بسيطة من سجلات الحيازة الزراعية بالجمعيات

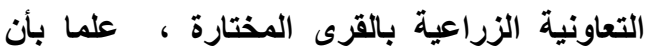
إجمالى عدد الحائزين بالقرى الأربعة قد بلغ الغرئ 6230 حائزا ، منهم1350 مزارعا بقرية أبو كلس، و ولائرئ 2400 حائزا بقرية ساحل الجوابر ، و1795 حائزا بقرية العراقية ، و685 حائزا بقرية كفر دنثواى. وقد روعى فى إختيار الحائزين (المبحوثين) بالعينة أن يكون لديهم حيوانات مزرعية وطيور منزلية داجنية وذلك لتحقيق أهداف الدراسة.

[3] جمع البيانات: إستخدام الاستبيان بالمقابلة الثخصية الثئة فى جمع البيانات الميدانية لهذه الدراسة ، وذلك بعد الئان إختبار صلاحية صحيفة الاستبيان (الاختبار المبلئى

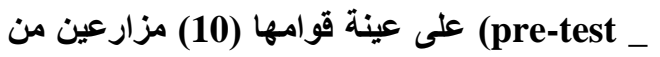
إحدى قرى مركز الباجور بالمحافظة، ومن خلال ذلكت تم إعادة صياغة بعض العبارات لتكون أسئلة الصحيفة فى سياق واحل ، وحتى تتناسب مع مستوى فهم المبحوثين، وقد إثتملت صحيفة الاستبيان على والى مجموعة من الأسئلة لقياس درجة معرفة وتطبيق الزراع لبعض الممارسات غير الأمنة فى مجالى الألى الإنتاج الحيوانى والاجنى ، كذلك إشتملت على الأنى المتغيرات المستقلة التى يعتقد بوجود علاقة لها مع الإتئ المتغيرات التابعة للاراسة. ولقد إستغرقت الفترة الزمنية لجمع البيانات شهرى يوليو ، أغسطس لأنس

.2018

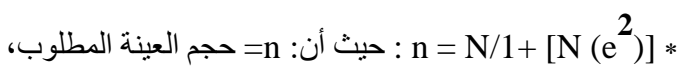

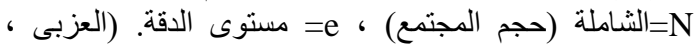

.(34-33: 2017 
1- عنـدما أقتــع بفكرة جديـدة أطبقهــا مباشـرة دون تردد، 2- يوجد لاى الدافع للبحث عن طرق وأسـاليب جديدة ، 3- أقوم بإعطاء النصيحة لجير انسى لتطبيق الأشياء الجديدة فى الزراعة مستقبلا ، 4- سوف أباعط أنفذ

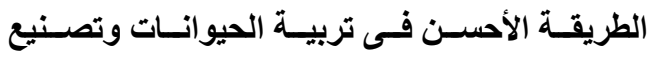
المنتجات حتى لو إختلفت عن الطريقة التى أستخدمها ، 5- الطرق الجديدة فى تربية الحيوانـات والدواجن

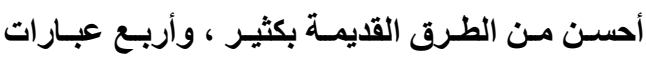

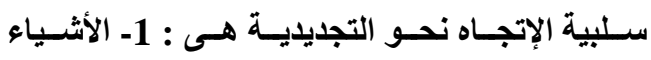
والأفكـار الجديدة التحى تقدمها وزارة الزراعـة تقلـل الإنتاج ، 2- لا أجازف بتطبيق أى فكرة جديدة مهــا كاتت النتائج ، 3- أفضل إستخدام الأسلوب الأنى يتبعه

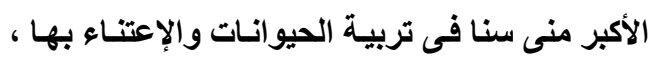
4- إذا أوصسى الطبيب البيطرى بفكرة جديدة تخص الخص

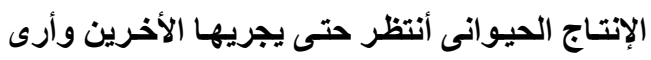

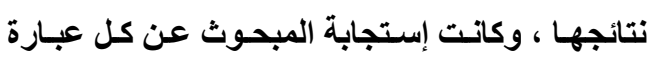

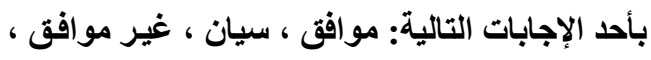

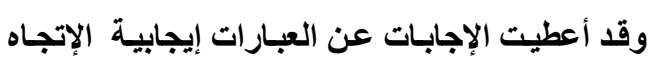

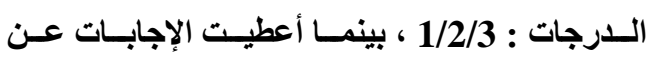
العبـارات سـلبية الإتجــاه الــدرجات : 3/2/1 علـى ، الترتيب، وجمعت الدرجات التى حصل عليها المبحوث وإستخدمت كمؤشر يعكس إتجاهه نحو التجديدية في ولى مجالى الأنتاج الحيوانى والداجنى.
المعيثـى ، وتـم قياسـه بسؤال المبحـوث عن درجـة

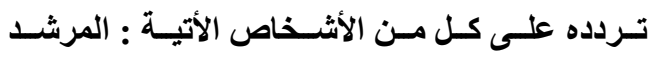

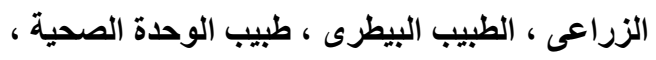

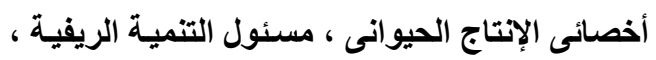

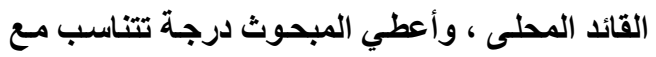

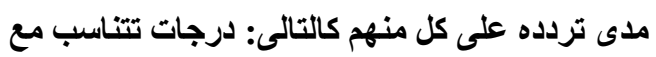
مدى تردده لكل شـص كالتـالي: كل يـوم = 4 ، كل كل

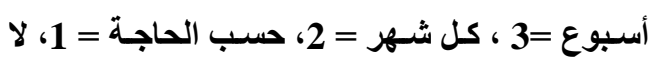
أذهـب = 0 ، وجمعـت الـدرجات التـى حصـل عليهـا

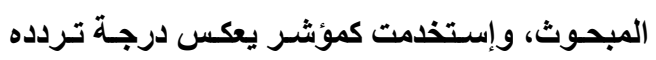
على وكلاء التغيير. (10) درجة التردد على المراكز الخدمية : تمث قياس هذا

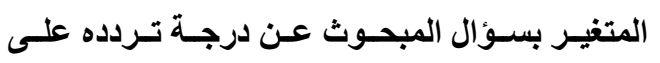

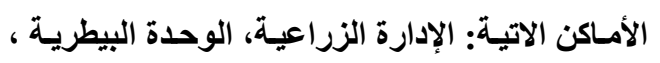

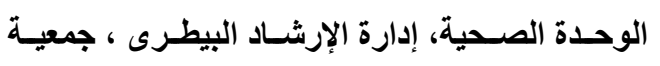

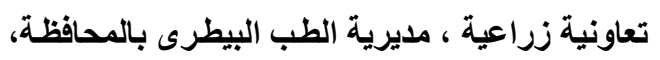

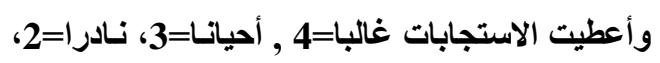
وأعطى المبحوث=1 فى حالة عدم التردد، وتم جمع

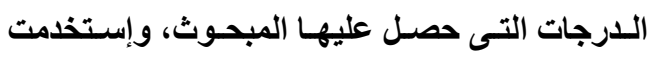
كمؤشر يعكس درجة تردده على المراكز الخدمية . (11) إتجـاه المبحوث نحو التجديليـة في مجـالى الإنتـاج

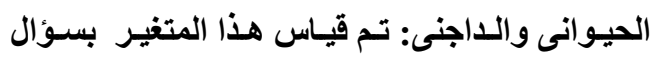

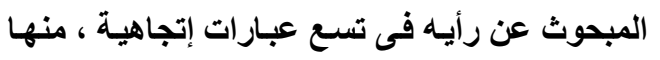
خمس عبـارات إيجابية الإتجـاه نحو التجديديـة هـى :

جدول رقم1. نتائج توصيف العينة فى ضوء المفاهيم الاجرائية لمتغيرات الدراسة

\begin{tabular}{|c|c|c|c|c|c|}
\hline المدى & أكبر قيمة & أقلّل قيمة & الاتحراف المعيارى & |المتوسط الحسابي & متغيرات الاراسة \\
\hline & & & & & أولا المتغيرات المستقلة: \\
\hline 46 & 73 & 27 & 7.2 & 54.2 & 1. 1السن \\
\hline 16 & 16 & $\mathbf{0}$ & 6.2 & 8.2 & 2. مستوى تعليم المبحوث \\
\hline 2600 & 30000 & 400 & 560.4 & 11188.5 & الاخل الثهرى للمبحوث \\
\hline 4 & 7 & 3 & 0.86 & 4.26 & حجم الأسرة \\
\hline 13 & 16 & 3 & 2.8 & 9.5 & مستوى تعليم الأسرة \\
\hline 7700 & 7700 & $\mathbf{0}$ & 1431.2 & 1628.1 & متوسط الدخل الثهرى للأسرة \\
\hline 45 & 54 & 9 & 15.69 & 20.75 & 7- ديموقر اطية اتخاذ القرار \\
\hline 55 & 60 & 5 & 13.2 & 28.4 & 8. الخبرة الوظيفية للمبحوث \\
\hline 24 & 24 & $\mathbf{0}$ & 2.42 & 5.28 & 9. درجة التردد على وكلاء التغيير \\
\hline 18 & 24 & 6 & 2.8 & 15.6 & 10. درجة التردد على المراكز الخدمية \\
\hline 13 & 22 & 9 & 2.28 & 15.66 & 11. درجة توافر أسواق الماشية والدواجن \\
\hline 16 & 24 & 8 & 4.74 & 18.8 & 12. درجة تو افرمستلزمات الانتاج الحيو انى والاجنى \\
\hline 19 & 27 & 9 & 3.01 & 19.1 & 13. الإتجاه نحو التجديدية \\
\hline 20 & 30 & 10 & 3.3 & 24.2 & 14. الاتجاه نحو المشاركةٌ التطوعية \\
\hline 14 & 21 & 7 & 2.2 & 14 & 15. درجة الثقة فى الأجهزة الحكومية \\
\hline
\end{tabular}


F.A. Salama, et al.,

\begin{tabular}{|c|c|c|c|c|c|}
\hline 12 & 18 & 6 & 2.27 & 12.72 & 16. الرضا المجتمعى المحلى \\
\hline 28 & 42 & 20 & 3.6 & 28.8 & 17. الاتجاه البيئى \\
\hline 55 & 60 & 5 & 13.2 & 28.4 & 18. حجم الحيازة الحيوانية والداجنية \\
\hline 231.5 & 243.2 & 151.6 & 29.8 & 199.9 & 19. المستوى الإقتصادى والمعيشى \\
\hline 29 & 57 & 28 & 6.30 & 42.66 & 20. درجة الانفتاح الجغرافى والثقافى \\
\hline 18 & 27 & 9 & 4.6 & 21.9 & 21. درجة الرضا عن جدوى تربية الحيوانات والطيور \\
\hline 111 & 249 & 138 & 20.39 & 181.61 & 22. درجة معارف المبحوث المرتبطة بالاتتاج الحيوانى و الاجنى \\
\hline & & & & & ثانيا المتغيرات التابعة: \\
\hline 60 & 120 & 60 & 0.50 & 74.71 & 1. درجة المعرفة بالممارسات غير الأمنة \\
\hline 87 & 90 & 3 & 0.74 & 51.04 & 2. درجة التطبيق للممارسات غير الأمنة \\
\hline
\end{tabular}

(14) الرضا المجتمعى المحلى : ويشير إلى درجة إرتباط

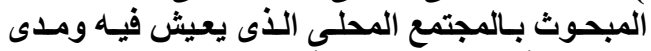

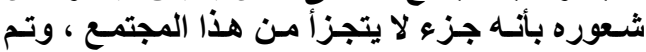

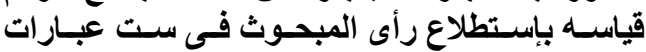

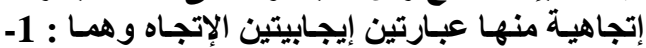

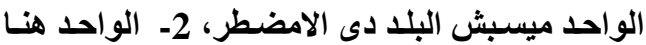

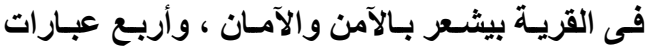

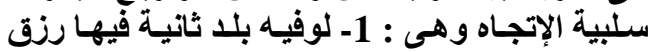

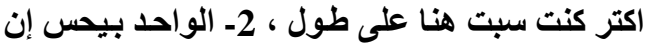

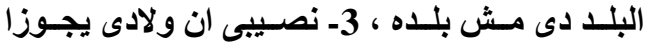

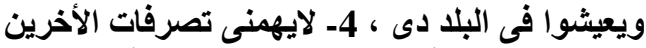

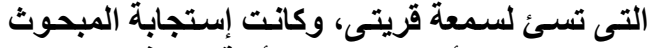

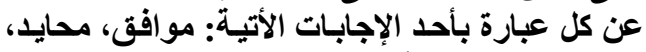

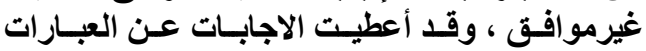

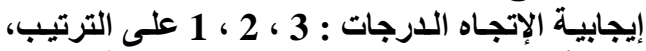

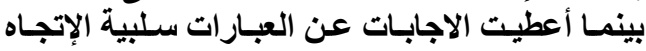

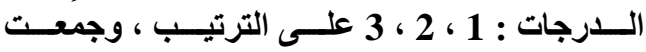

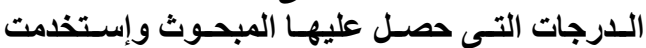

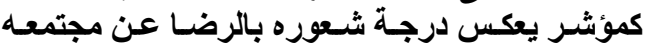

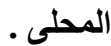

(15) الإتجاه البيئى : ويقصد به درجة إستجابه المبحوث

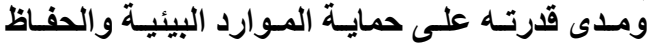

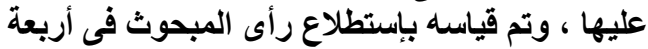

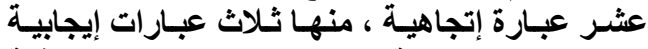

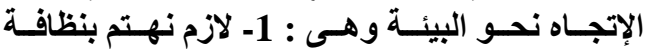

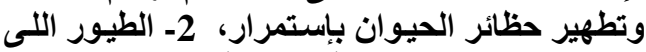

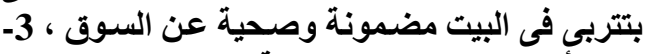

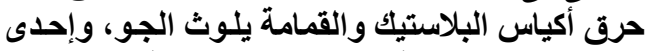

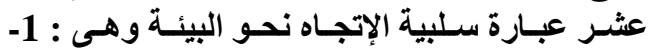

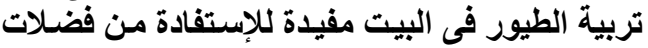

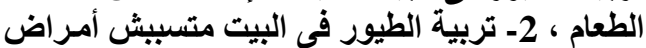

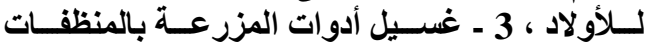

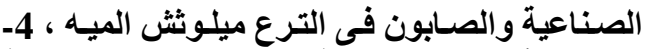

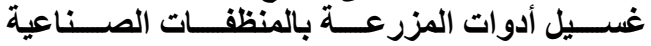

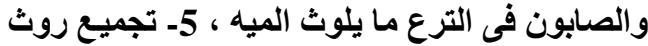

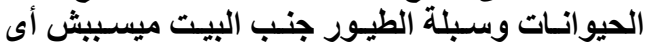

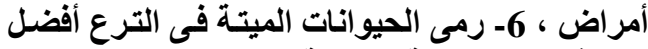

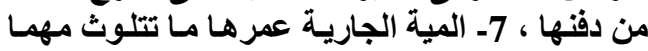

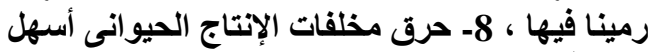
طريقة للتخلص منهـا ، 9- رش المبيدات فى البيت اليت الئل
*المصدر : جمت وحسبت من بيانات الدراسة الميدانية .

(12) إتجاه المبحوث نحو المشــاركة التطوعيـة : ويعبر

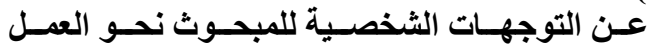

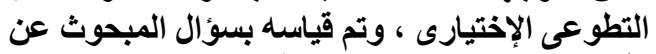

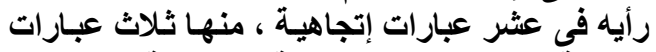

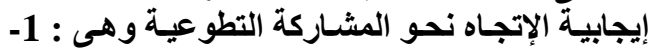

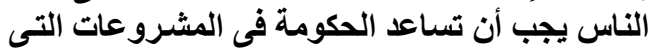

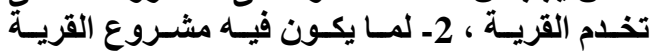

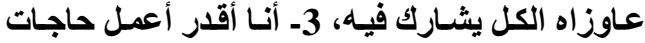

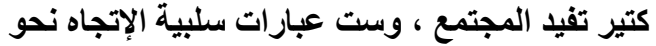

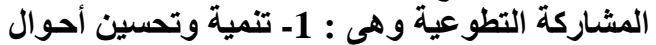

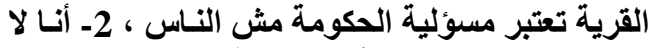

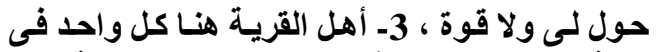

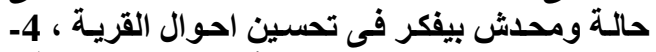

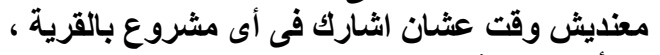

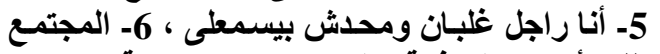

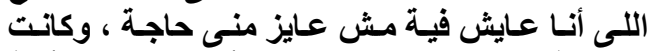
استجابة المبحوث عن كل عبارة بأحد الإجابات الأتية الإية

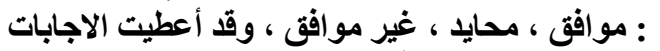

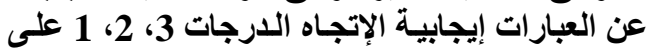
الترتيب ، بينما أعطيت الاجابات عن العبان العارجات العات سلبية

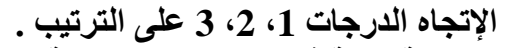

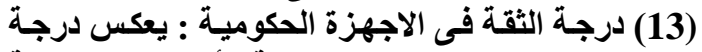

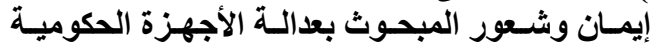

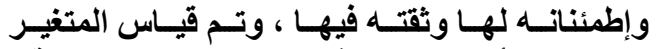

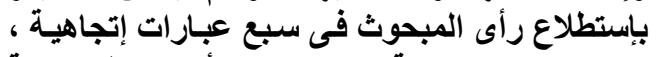
عبارتان منها إيجابية الإتجاه نحو الأجهزة الحبارئ الحكومية

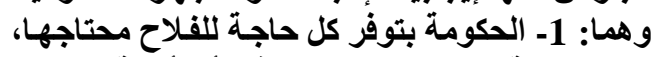

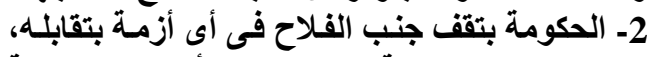
وخمس عبارات سلبية الإتجاه نحو الأجهزة الحكومية التهاتية

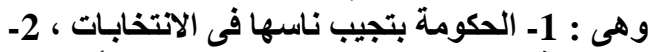

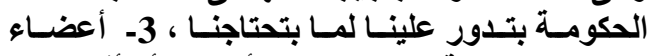

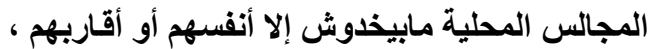

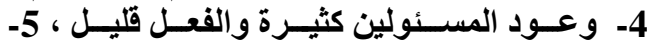

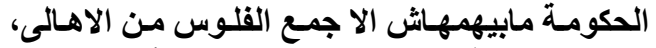

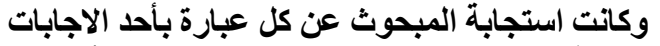

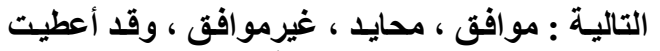

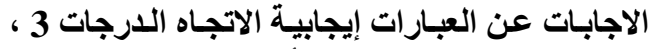

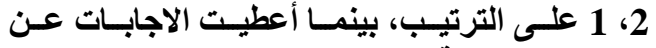

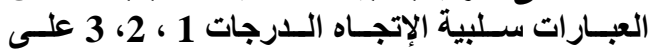
الترتيب . 


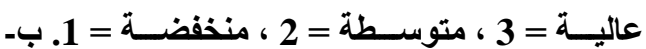

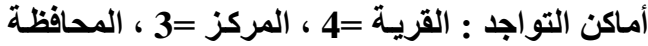

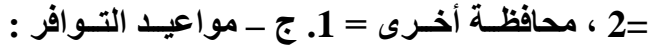

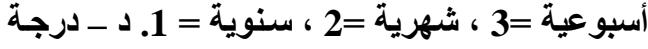
رضا المبحوث عن خدماتها: راضى =3 ،

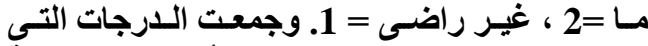

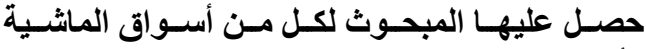

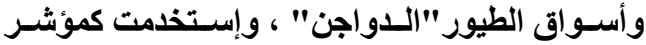

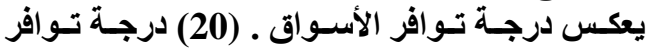

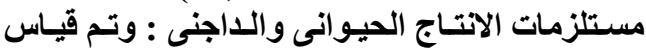

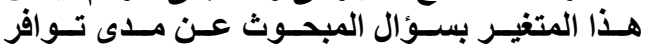

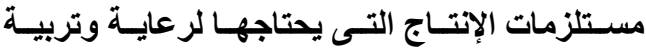

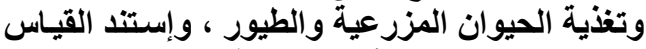

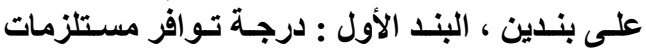

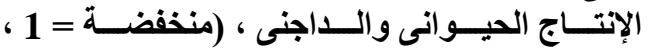

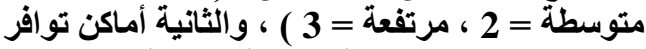

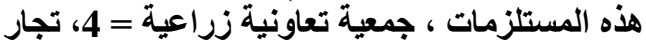

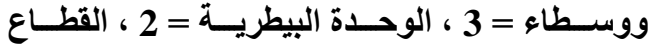

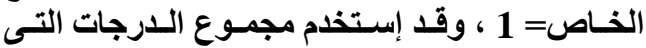

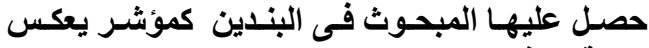

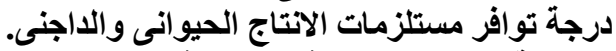

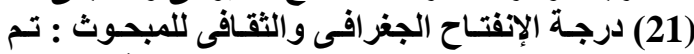

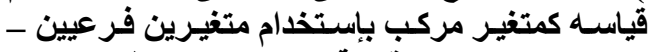

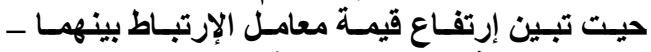

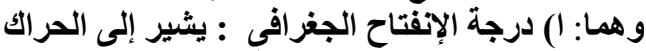

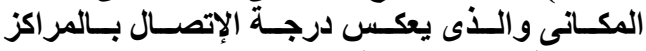

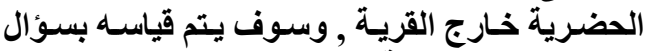

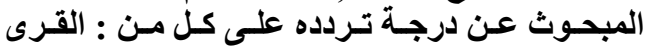

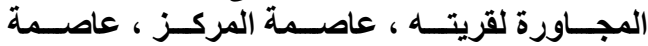

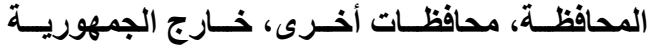
وأعطي المبحوث درجة تتناسب مع مدى تردئ افرده لكل

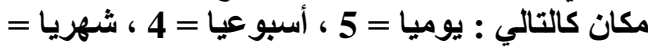

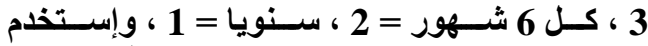

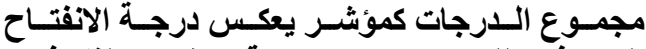

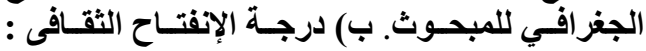

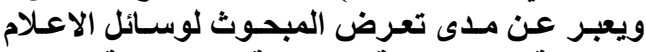

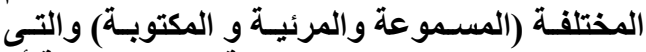

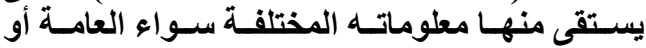

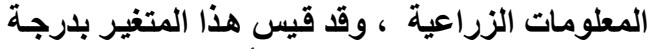

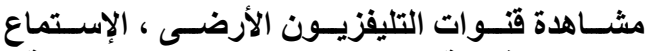

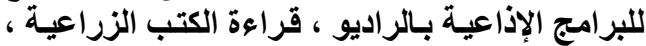

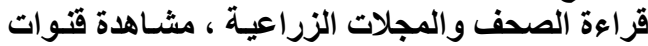

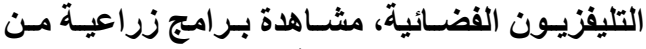

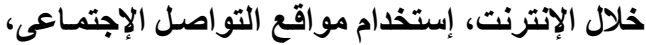

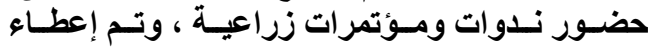

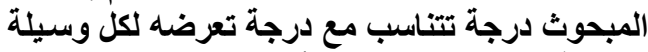

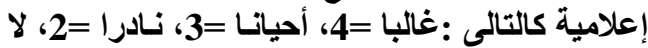

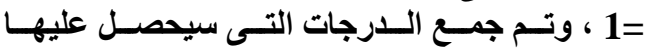

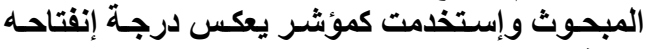
الثقافى. وجمعت الدرجات التى حصل عليها المبحوث

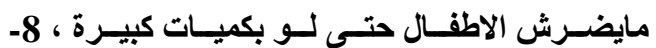

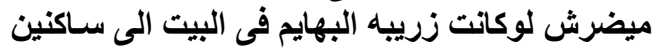

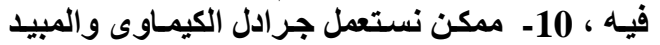

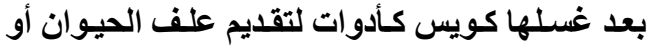

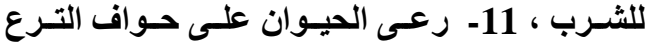

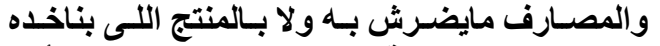

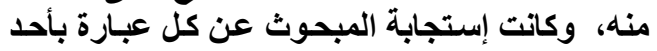

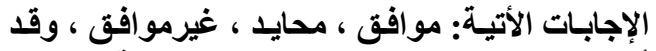

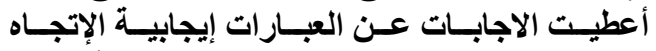

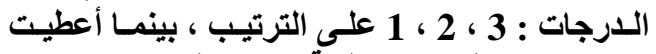

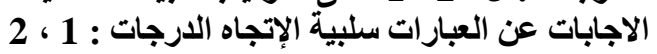

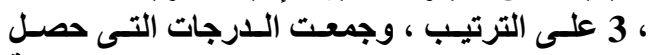

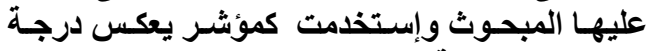
إتجاهه نحو البيئة

(16) الرغبة فى الإقتراض : تم قياس هذ الينة المتغير بسؤال

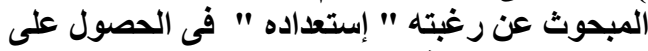

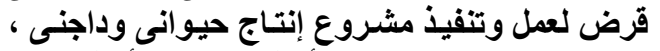

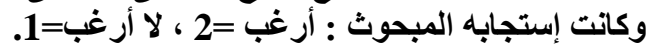

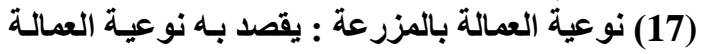

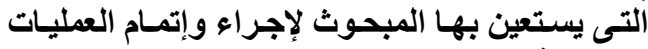

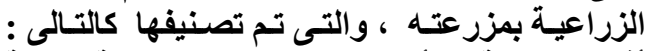

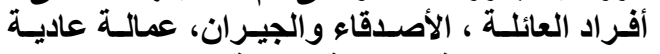

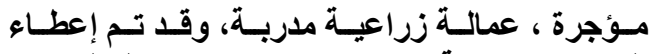

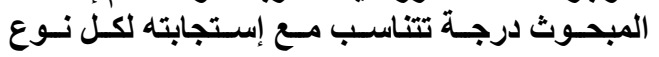

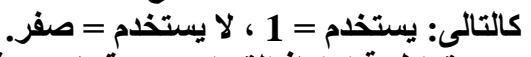

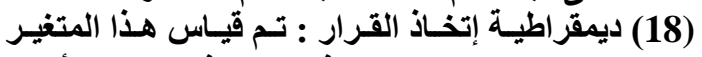

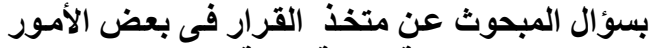

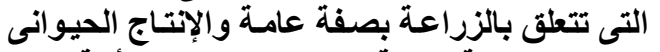

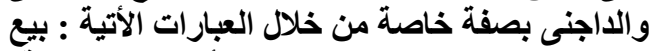

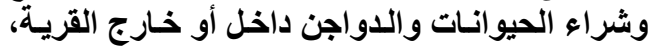

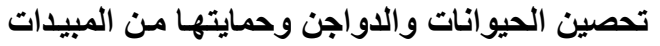

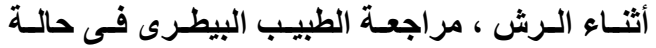

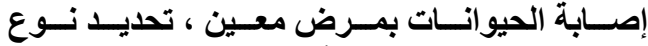

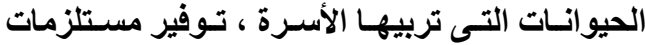

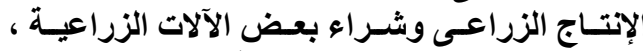

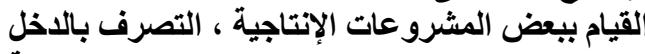

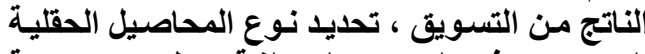

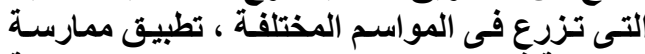

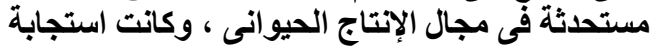

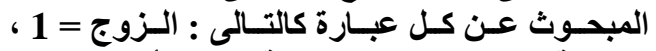

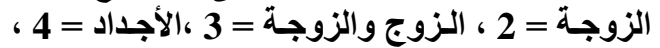

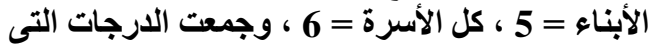

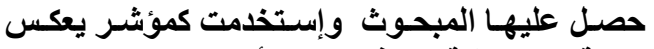
درجة ديمقراطية إتخاذ القرار الأسرى.

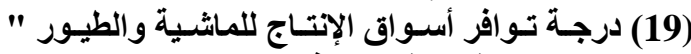

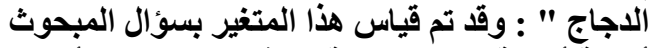

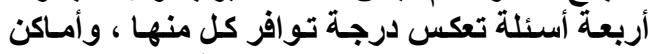

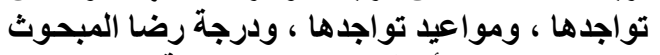

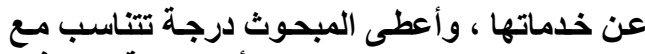

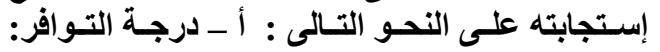


واحدة عن ملكية كل جهاز من الأجهزة الأتية : مكواه

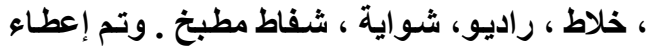

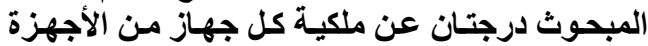

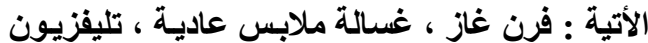

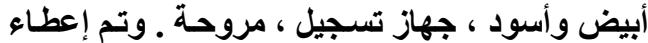

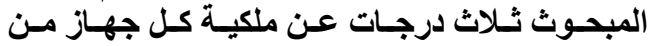

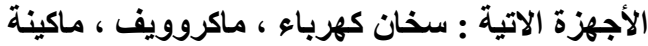

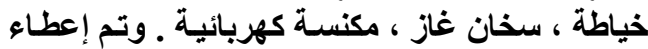

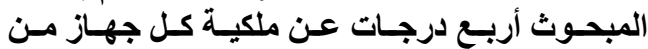

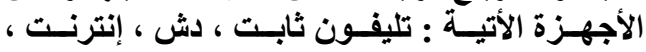

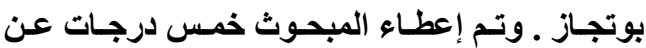

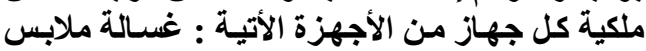

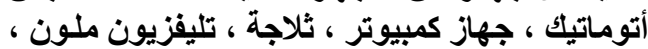

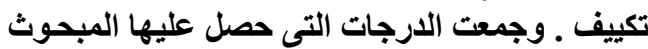

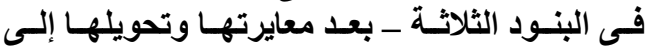

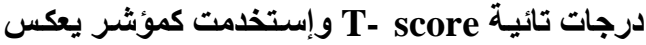

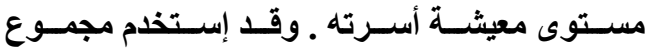

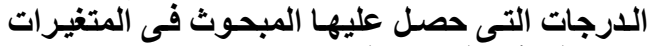

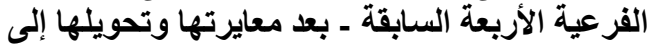

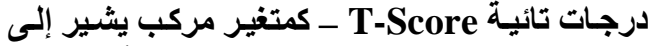
المستوى الإقتصادى و المعيثى للمبحوث و وأسرته.

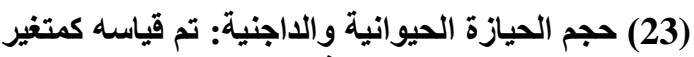

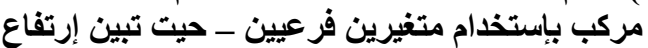

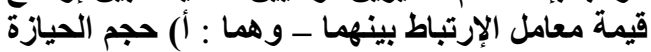

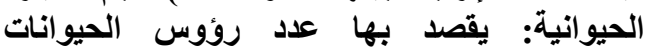
المزرعية التى تمتلكها أسرة المبحوث وتونية وتقوم

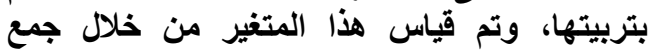

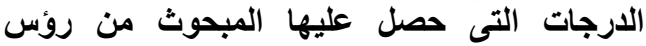
الحيوانات بعد معايرتها ، وإستخدم المجموع كمؤشر لئر

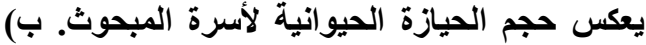

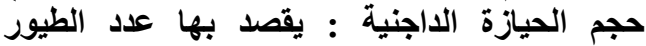

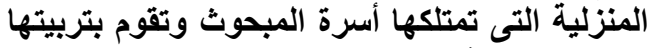

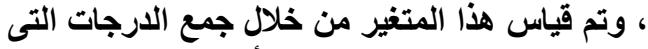

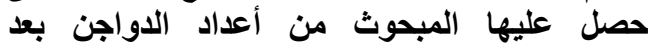

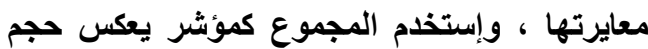

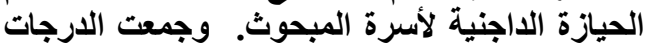

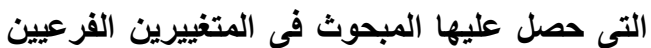

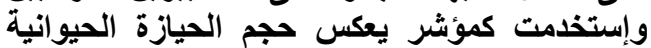
و الاجنية لأسرة المبحوث .

(24) درجة الرضا عن جدوى تربية الحيو انات المزرعية

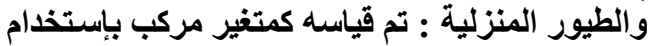
متغيرين فرعيين ـ نظرا لإرتفاع قيمة معامل الإرتباط

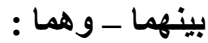
أ) درجة الرضا عن تربية الحيوانات المزرعية : تم قياس

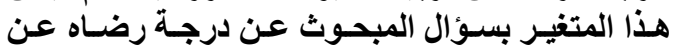

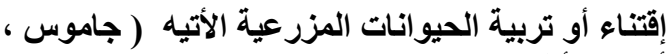

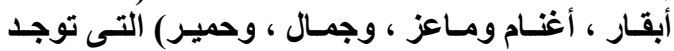

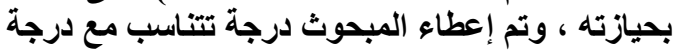

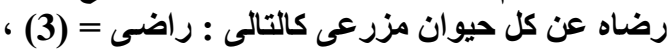

فى المتغييرين الفرعيين وإستخدمت كمؤشر يعكس درجة إنفتاحة الجغرافى والثقافى.

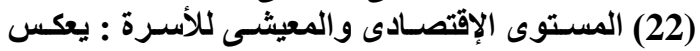

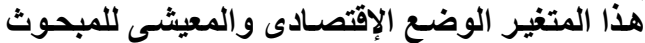

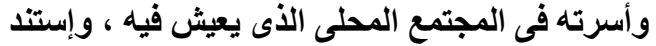

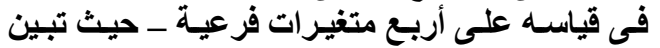

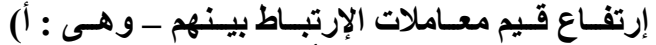

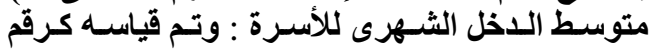

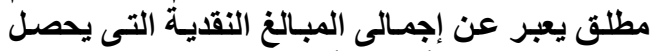

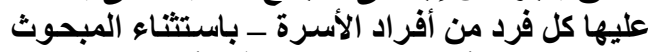

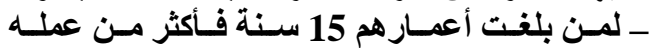

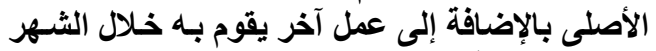

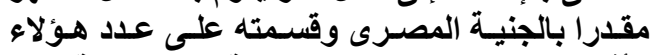

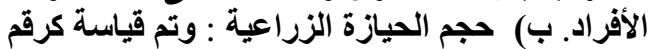

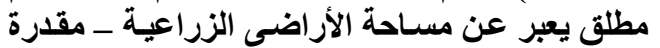
بالقيراط - التى تمتلكها أو تستأجرها الأسرة الزبرة المبحوث

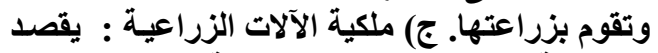

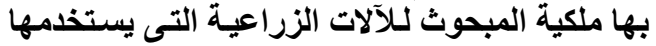

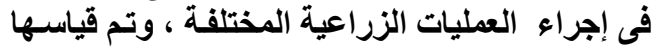

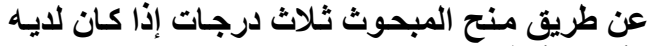
الألات الأتية (جرار زراعى ، تروسيكل ، كابس تبني)،

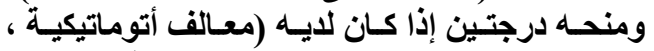

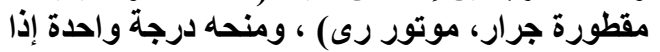

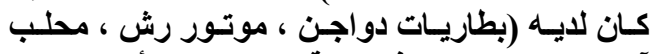

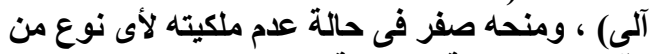

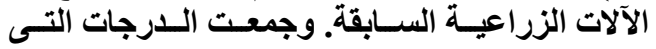

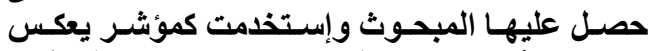

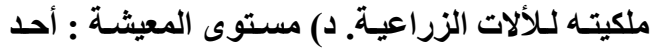

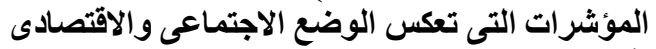

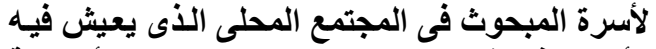

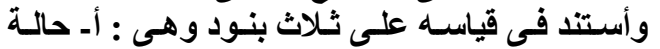

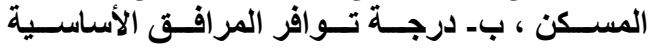

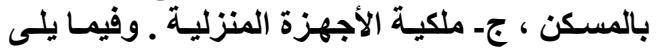

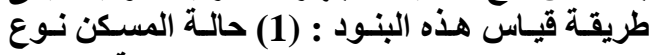

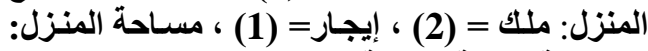

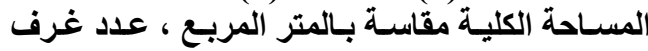

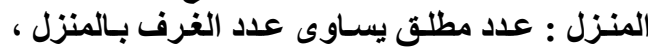

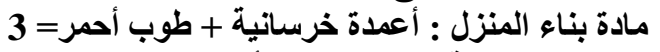

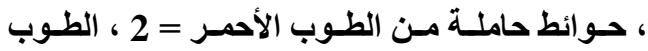

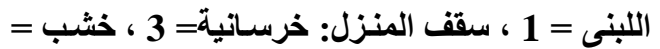

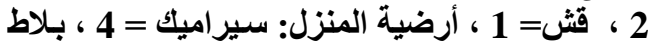

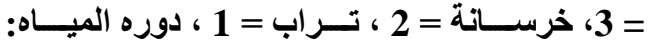

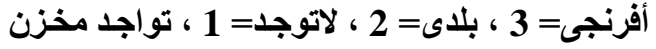

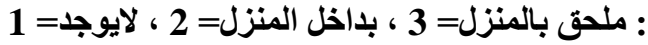

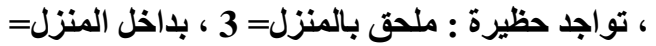

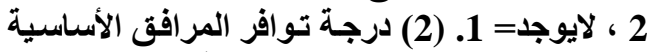

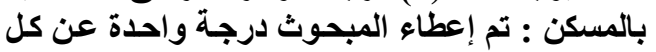
مرفق متو افر فى المسكن من المر افق الأساسية الأتية

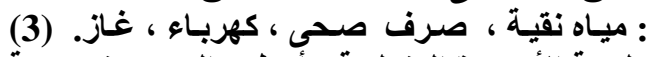

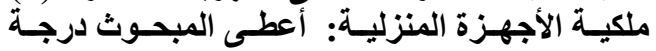


ج) درجة المعارف البيطرية : يثير هذا المتغير إلى درجة

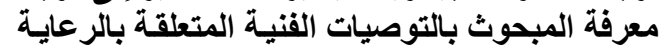

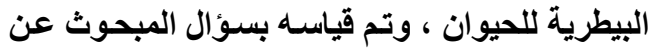

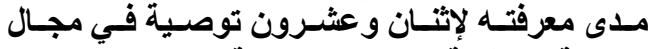

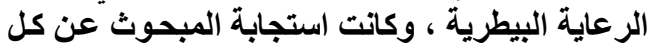

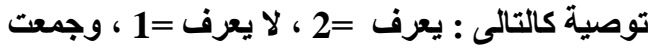

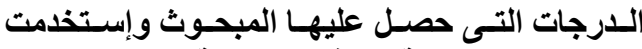
كمؤشر يعكس درجة معرفته البيطرية.

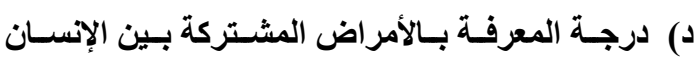

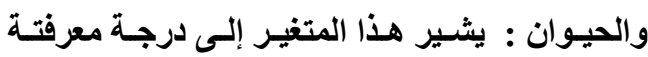

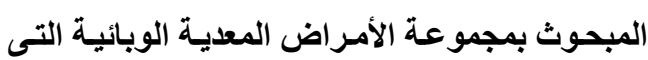

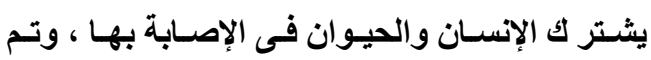
قياسه بسؤال المبحوث عن مدى معرفته بإثنى عثر لإنس مرضا مشتركاً بين الإنسان و الحيوان فى الإصابة بها وهى : 1- الجرب و القراع ، 2- الحمى القلاعية ، 3-

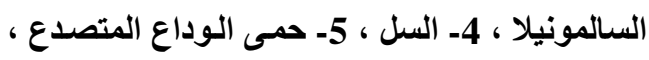

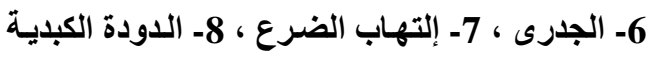

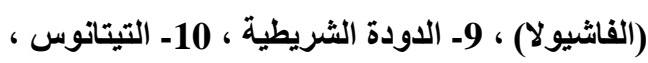
11- جنون البقر ، 12- الإجهاض المعدى (البروسيلا ) ، وكاتت استجابة المبحوث عن كل مرض كالتالى :

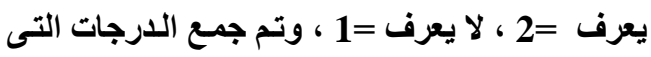

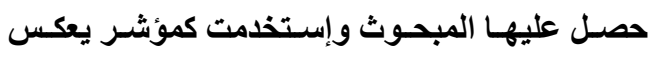
درجـة معرفتـهـ بـالأمراض المشـتركة بـين الإنســان والحيوان. ه ) درجة معرفة التأثير السلبى للممارسات غير الآمنة :

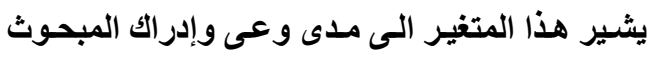

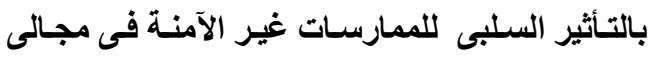

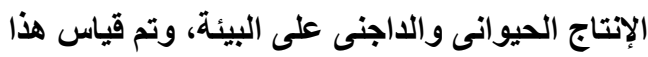

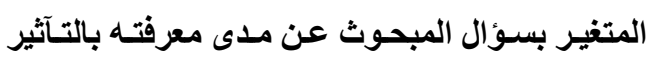

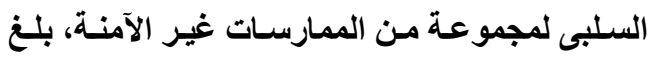
عددها إثنـان و عشـرين ممارسـة غير امنـة لتنأثيرهـا

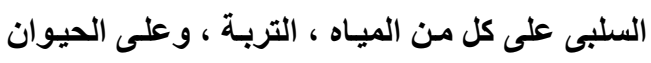

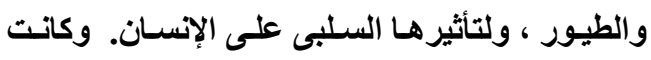

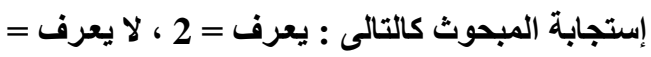

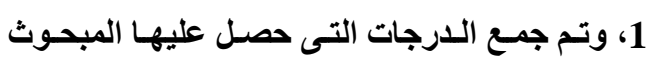
وإستخدمت كمؤشر يعكس درجة معرفته فئه في التأثير السلبى للممارسـات غير الآمنـة في مجـالى الإنتـاج

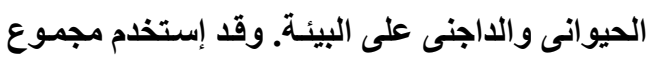

راضى إلى حد ما = (2) ، غير راضى = (1)، وجمعت

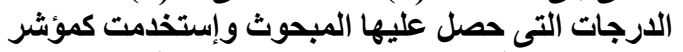

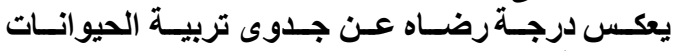

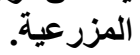

ب) درجة الرضـا عن تربية الطيور المنزلية : تم قياس

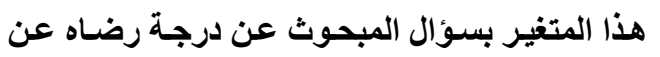

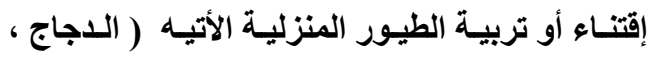

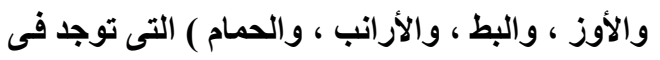

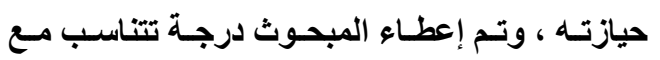
درجة رضاه تربية كل من الطيور المنزلية التالية :

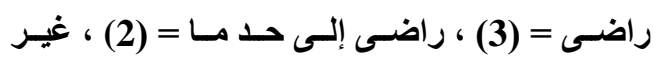
راضس = (1) , وجمعت اللارجات التى حصل عليها المبحوث و إستخدمت كمؤشر يعكس درجة رضاه

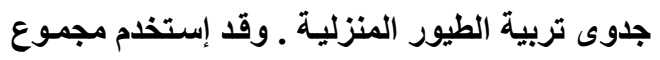
الارجات التى حصل عليها المبحوث فح المتغييرين

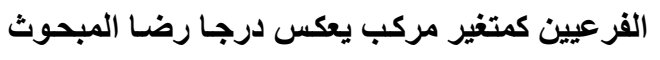

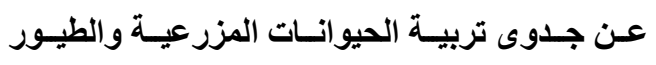

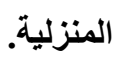

(25) درجة معارف المبحوث المرتبطة بالإتتاج الحيوانى

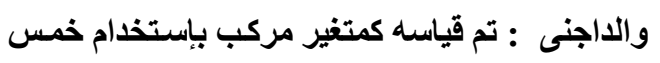

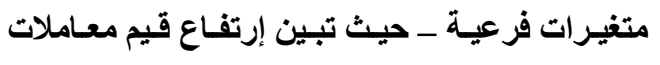
الإرتباط البسيط بينهم - وفيما يلى طريقة قياس كل فئل منهم: أ) معرفـة المبحوث للتوصيات الفتيـة فى مجـال الإنتـاج

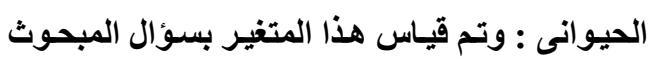

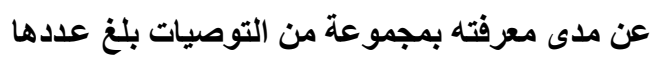
سبعة وثلاثون توصية ذات صـلة بكل مـن : تربيـة

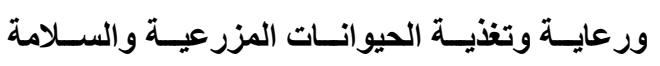
الصحية والحفاظ على البيئة.

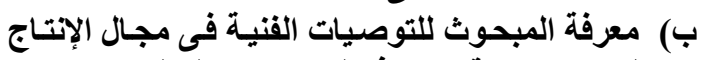

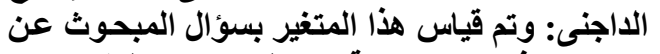

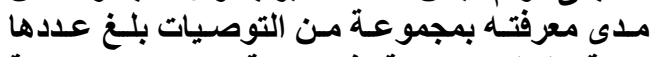

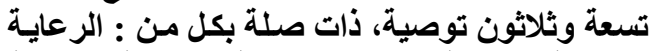

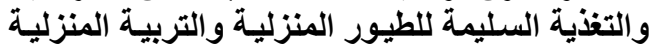

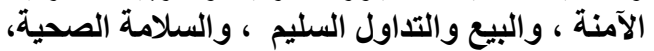

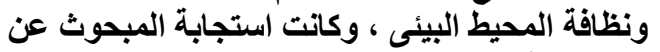

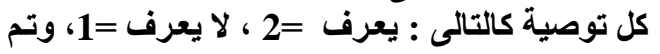

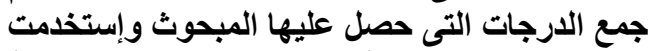

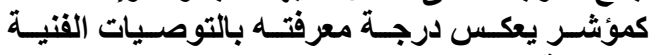

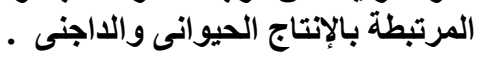


المتغير التابع الثانى : درجة تطبيق الزراع " المبحوثين

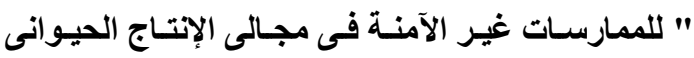

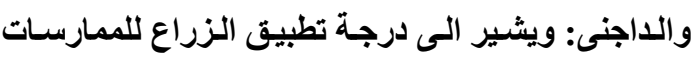

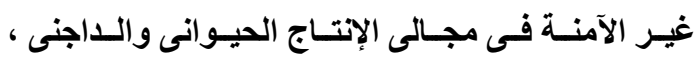
وإعتمد فى قياسه على بنديين رئيسيين هما: البند الأول:

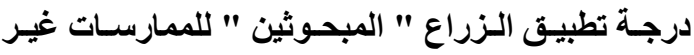
الآمنـة فى مجـال الإنتـاج الحيوانى : وتم قياسـه بسؤئال المبحوث عن درجة تطبيق ثلاثين ممارسـة غير آمنة فى هذا المجال ، ( والمشـار إليها بجدول رقم 6 فى نتائج

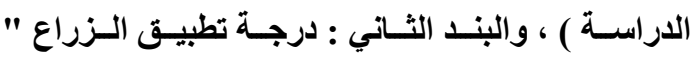
المبحوثين " للممارسـات غير الآمنـة فى مجـال الإنتـاج الاجنى : وتم قياسـه بسؤال المبحوث عن درجة تطبيق الثلاثين ممارسة غير آمنة فى هذا المجال ، ( والمشار إليها بجدول رقم 7 فى نتائج الدراسـة ) ، وتم إعطاء المبحوث درجة تتناسب مع درجة تطبيقه لكل ممارسـة

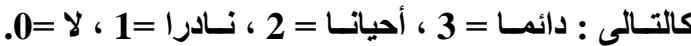
وجمت الدرجات التى حصل عليها المبحوث فى البندين الأول والثانى ، وإستخدمت كمؤشر يعكس درجة تطبيقه

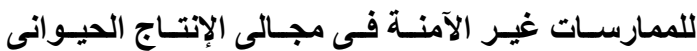

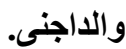

اللارجات التى حصل عليها المبحوث فى المتغيرات

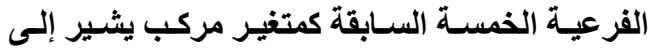
درجة معارف المبحوث المرتبطة بالإنتاج الحيوانى

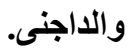

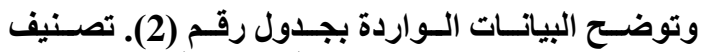
المبحوثين وفقا للمتغيرات البحثية المستقلة التى تناولتها

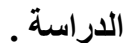

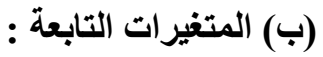

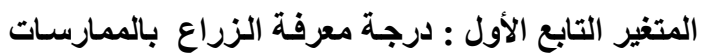
غير الآمنة فى مجالى الإنتاج الحيوانى والداجنى : يثير الإن

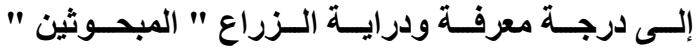

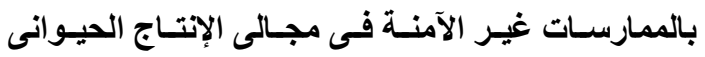
و الاجاجنى ، وإعتمد فى قياسه على بندين رئيسيين، هما:

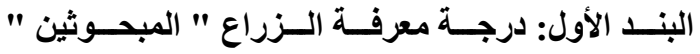

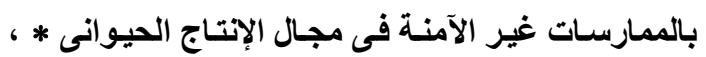

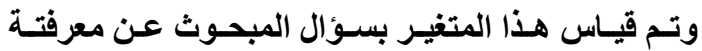

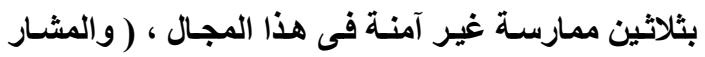
إليها بجدول رقم 3 فى نتائج الدراسـة ) ـ والبند الثاني :

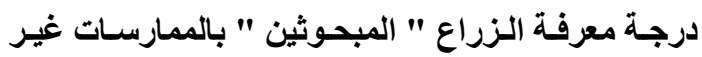

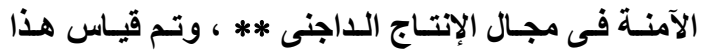
المتغير بسؤال المبحوث عن معرفتة بثلاثين ممارسة غير

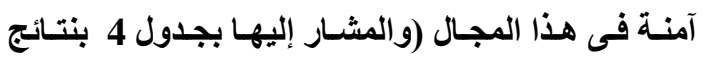
الاراسة ) وتم منح المبحوث درجة تتناسب ميع إستجابتة

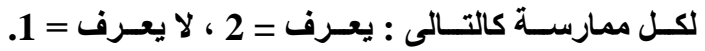
وجمعت الدرجات التى حصل عليها المبحوث فى البندين الأول والثانى ، و إستخدمت كمؤشر يعكس درجة معرفته بالممارســات غير الآمنـة فـى مجـالى الإنتـاج الحيـوانى

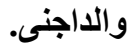

$$
\begin{aligned}
& \text { * تم التعرف على وتحديد الممارسات غير الآمنة موضع الدراسة والمتعلقة }
\end{aligned}
$$

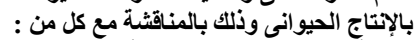

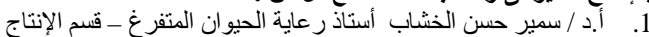

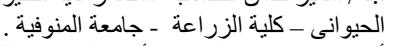

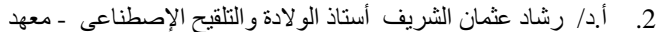

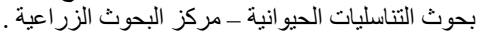

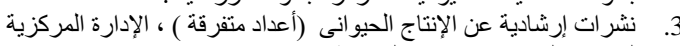

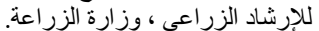


Menoufia J. Agric. Economic \& Social Sci. Vol. 4 February (2019): 55 -93

جدول رقم 2. تصنيف المبحوثين وفقا للمتغيرات البحثية المستقلة التى تناولتها الدراسة.

\begin{tabular}{|c|c|c|c|c|c|}
\hline$\%$ & $318=\dot{0}$ & الخصائص "المتغيرات المستقلة" & $\%$ & $318=\dot{0}$ & الخصائص "المتغيرات المستقلة" \\
\hline & & 12- الاتجاه البيئى : & & & 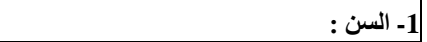 \\
\hline 6.7 & 21 & سلبى (14-23 درجة) & 18.5 & 58 & صغار (27- 42 سنة) \\
\hline 76.4 & 243 & محايد (24-32 درجة) & 39.3 & 125 & متوسطى (43- 58 سنة) \\
\hline \multirow[t]{2}{*}{16.6} & 54 & | ايجابى (32-42 درجة) & 42.4 & 135 & كبار (59-73 سنة) \\
\hline & & \multicolumn{2}{|l|}{ 13- ديموقر اطية اتخاذ القرار : } & & 2- مستوى تعليم المبحوث : \\
\hline 74.7 & 237 & منخفض (93-9 درجة) & 40.5 & 99 & منخفض (صفر - 5 سنوات) \\
\hline 3.8 & 12 & متوسط (24-39 درجة) & 2.16 & 26 & متوسط (6-11 سنة) \\
\hline \multirow[t]{2}{*}{21.6} & 69 & مرتفع (40 -54 درجة) & 57.5 & 193 & مرتفع (12- 16سنة) \\
\hline & & \multicolumn{2}{|l|}{ 14- درجة توافر أسواق الماشية والدواجن : } & & 3- الدخل الثهرى للمبحوث : \\
\hline 15.5 & 49 & منخفضة (13-9 درجة) & 61.3 & 195 & منخفض ( 400-1266 جنية) \\
\hline 79.6 & 254 & متوسطة (18-14 درجة) & 35.2 & 112 & متوسط (1267-2133جنية) \\
\hline \multirow[t]{2}{*}{4.7} & 15 & مرتفعة (19-22 درجة) & 3.4 & 11 & مرتفع (2134-3000جنية) \\
\hline & & \multicolumn{2}{|l|}{ 15- المستوى الاقتصادى و المعيثى للأسرة : } & & |- حجم الأسرة : \\
\hline 81.4 & 259 & منخفض (288.8-151.6 درجة) & 50.6 & 161 & صغير (3-4أفراد) \\
\hline 17.6 & 56 & متوسط (305.8-289.8 درجة) & 44.6 & 142 & متوسط (5-6أفراد) \\
\hline \multirow[t]{2}{*}{0.94} & 3 & مرتفع (306.8- 383.درجة) & 4.7 & 15 & كبير (7 أفراد) \\
\hline & & \multicolumn{2}{|l|}{ 16- حجم الحيازة الحيوانية والداجنية: } & & 5- مستوى تعليم الأسرة : \\
\hline 74.2 & 236 & منخفضة ( 716.4-601.4 وحدة حيو انية) & 18.5 & 59 & منخفض (-3 سنة) \\
\hline 22.1 & 70 & متوسطة ( 831.4-717.4 وحدة حيو انية) & 67.6 & 215 & متوسط (12-8 سنة) \\
\hline \multirow[t]{2}{*}{3.7} & 12 & مرتفعة (948.3-842.4 وحدة حيوانية) & 13.8 & 44 & مرتفع (16-13سنة) \\
\hline & & 17- درجة الانفتاح الجغرافى و الثقافى : & & & 6- اتجاه المبحوث نحو التجديدية : \\
\hline 19.8 & 63 & منخفض (28-37 درجة) & 11.8 & 38 & سلبى ( 15-9 درجة) \\
\hline 60.1 & 191 & متوسط (47-38 درجة) & 66.1 & 210 & | محايد (16-22 درجة) \\
\hline \multirow[t]{2}{*}{20.1} & 64 & مرتفع (48-57 درجة) & 22.1 & 70 & (ايجابى (23-27 درجة) \\
\hline & & 18-درجة الرضا عن جدوى تربية الحيو انات والطيور : & & & 7- الخبرة الوظيفية للمبحوث : \\
\hline 11.9 & 38 & منخفضة (14-9 درجة) & 30.1 & 96 & منخفضة (5-5 سنة) \\
\hline 38.9 & 124 & متوسطة (15-22 درجة) & 55.9 & 187 & متوسطة (42-24 سنة) \\
\hline \multirow[t]{2}{*}{49.1} & 156 & مرتفعة (23-23 درجة) & 13.8 & 44 & مرتفعة (57-43 سنة) \\
\hline & & 19- درجة الثقة فى الأجهزة الحكومية : & & & | 8- درجة التردد على وكلاء التغيير : \\
\hline 18.8 & 60 & منخفض ( 7- 11 درجة) & 88.9 & 283 & | منخفض (صفر-7 درجات) \\
\hline 56.9 & 181 & متوسط (12- 16 درجة) & 10.6 & 34 & متوسط (8-16 درجة) \\
\hline \multirow[t]{2}{*}{24.2} & 77 & مرتفع (17- 21 درجة) & 0.31 & 1 & مرتفع (17-24 درجة) \\
\hline & & 20- درجة توافر مستلزمات الاتتاج الحيو انى و الداجنى: & & & |9ـــ درجة التردد على المراكز الخدمية : \\
\hline 15.1 & 48 & منذفضة (13-8 درجة) & 15.2 & 48 & منذفض (6-12 درجة) \\
\hline 38.6 & 123 & متوسطة (14-19 درجة) & 71.6 & 228 & متوسط ( 13-13درجة) \\
\hline \multirow[t]{2}{*}{46.4} & 147 & مرتفعة (24-20 درجة) & 11.2 & 42 & مرتفع (19-24درجة) \\
\hline & & 21-معارف المبحوث المرتبطة بالانتاج الحيو انى والداجنى & & & 10 اتجاه المبحوث نحو المشاركة التطوعية : \\
\hline 45.4 & 144 & منخفضة (175-138 درجة) & $\mathbf{0 . 6 0}$ & 2 & | سلبى (10-16 درجة) \\
\hline 44.6 & 142 & متوسطة (176-13 درجة) & 39.6 & 126 & | محايد (23-17 درجة) \\
\hline \multirow[t]{2}{*}{10.2} & 32 & مرتفعة (214-249 درجة) & 59.7 & 190 & | ايجابى (24-30 درجة) \\
\hline & & 22 - الرغبة فى الإقتراض : & & & 11- الرضا المجتمعى المحلى: \\
\hline 25.2 & 80 & 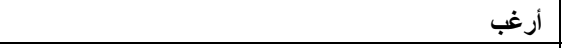 & 12.2 & 39 & منخفض (6-10 درجات) \\
\hline \multirow[t]{2}{*}{74.8} & 238 & ل ل أرغب & 64.3 & 204 & متوسط (11-11 درجة) \\
\hline & & & 23.5 & 75 & | عالى (15-15 درجة) \\
\hline
\end{tabular}


بالقرب من حظائر الحيوان والمنازل، رمى مخلفات

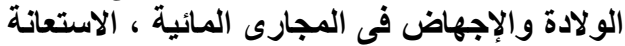

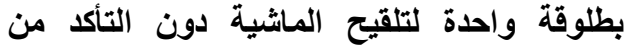

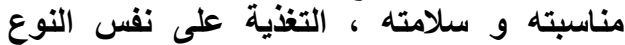

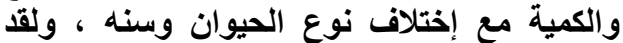

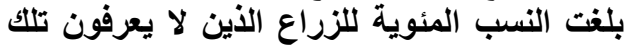

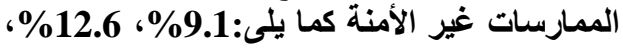

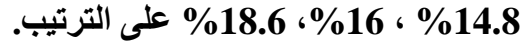

2) درجة معرفة الزراع بالممارسات غير الآمنة فى الإنى

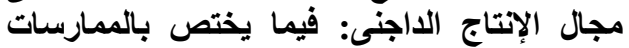

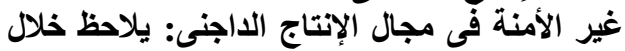

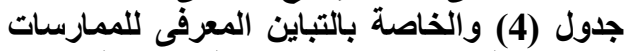

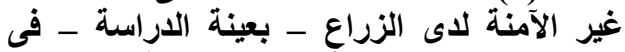

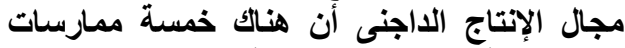

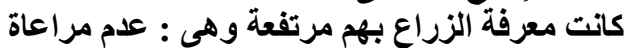

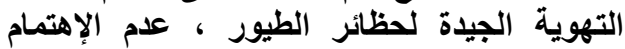
بالتحصينات الدورية للطيور ، عدم الإهتمام بغنيل الإنيل

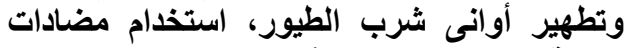

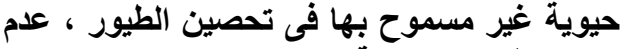

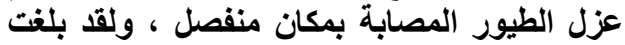

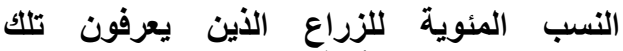

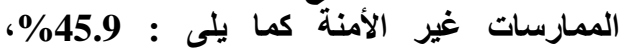

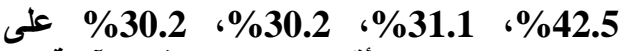

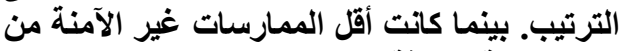

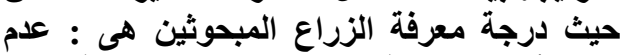

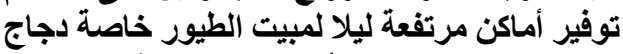

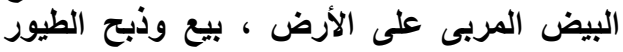

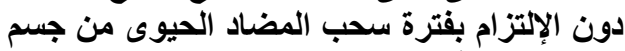

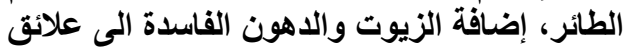

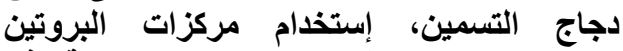
الحيوانى الغير مطابق للمواصفات الفنية فيرات فئ العلائق، ترك الحت
أولا: درجة معرفة الزراع بالممارسات غير الأمنة

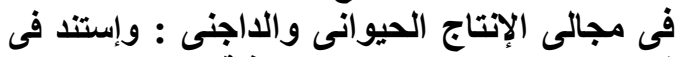

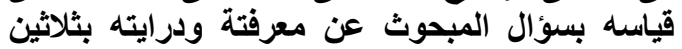

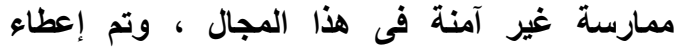

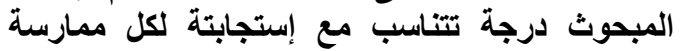

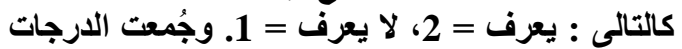

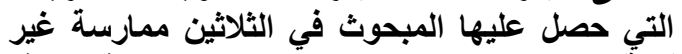

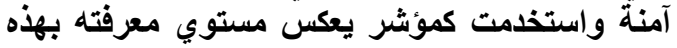

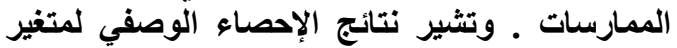
درجة المعرفة بالممارسات غير الآمنة إلى أنى الميات المدي المئي

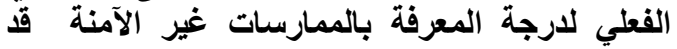

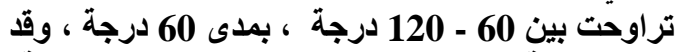

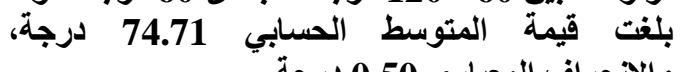
والانحراف المعياري 0.50 درجة.

1) درجة معرفة الزراع بالممارسات غير الآمنة فى فئ

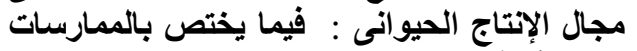

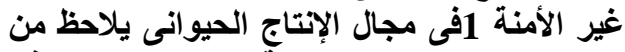

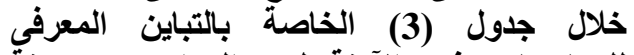

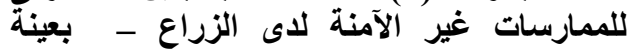

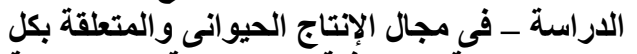
من " التربية، والتغذية مجالة ، والرعاية الترانية ، والسلامة

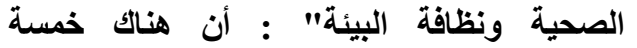

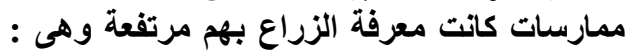

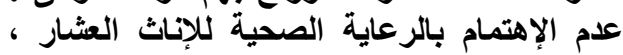

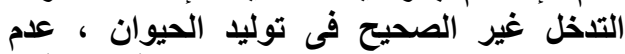

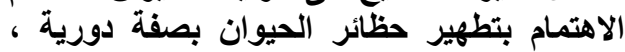

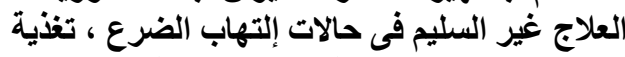

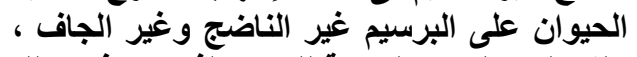

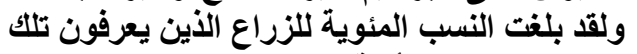

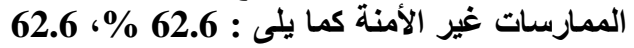

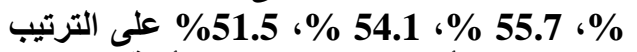

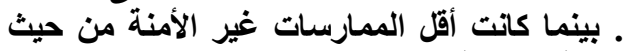
درجة معرفة الزراع المبحوثين هى إعلى إستعمال

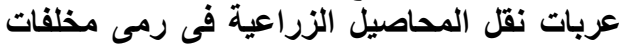

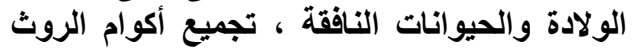
جدول رقم 3. درجة معرفة الزراع - المبحوثين - بالممارسات غير الآمنة فى مجال الإتتاج الحيوانى

\begin{tabular}{|c|c|c|c|c|c|}
\hline \multicolumn{4}{|c|}{ فئات المعرفة } & \multirow{3}{*}{ الممارسات غير الآمنة } & \multirow{3}{*}{ م } \\
\hline \multicolumn{2}{|c|}{ ل ل اليعرف } & \multicolumn{2}{|c|}{ 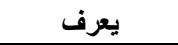 } & & \\
\hline$\%$ & ن & $\%$ & $\dot{ن}$ & & \\
\hline & & & & الممارسات غير الآمنة فى مجال تربية الحيوانات : & 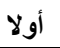 \\
\hline 40.5 & 156 & 50.9 & 162 & ذبح إناث الماشية فى الأعمار الصغيرة & 1 \\
\hline 75.7 & 241 & 24.2 & 77 & البيع الجائر للعجلات الإناث الصغيرة حديثى الولادة & 2 \\
\hline 70.4 & 224 & 29.6 & 94 & إستخدام حيوان إنتاج اللبن فى العمل لفترات طويلة & 3 \\
\hline 57.7 & 182 & 42.8 & 136 & تسكين العجول الرضيعة فى حظائر جماعية بعد الولادة & 4 \\
\hline 56.2 & 179 & 43.7 & 139 & تسكين الحيوان المصاب مع الحيوانات السليمة فى مكان واحد & 5 \\
\hline 44.3 & 141 & 55.7 & 177 & عدم الاهتمام بتطهير حظائر الحيوان بصفة دورية & 6 \\
\hline
\end{tabular}


F.A. Salama, et al.,

\begin{tabular}{|c|c|c|c|c|c|}
\hline & & & & الممارسات غير الآمنة فى مجال تغذية الحيوانات : & ثانيا \\
\hline 81.4 & 259 & 18.6 & 59 & التغذية على نفس النوع والكمية مع إختلاف نوع الحيوان وسنه & 1 \\
\hline 76.7 & 244 & 23.2 & 74 & تقديم الأعلاف بإلقائها مباشرة على الأرض & 2 \\
\hline 42.4 & 136 & 25.8 & 82 & وضع الأعلاف بالقرب من أماكن الثرب & 3 \\
\hline 72.9 & 232 & 27.2 & 86 & التغذية على الحبوب بثكل مباشر دون اجراء أيه معاملات عليها & 4 \\
\hline 68.2 & 217 & 31.8 & 101 & التظذية على بقايا الخبز ومخلفات المحاصيل الزراعية دون التأكد من سلامتها ونظافتها & 5 \\
\hline 48.1 & 153 & 51.5 & 165 & تغذية الحيوان على البرسيم غير الناضج وغير الجاف & 6 \\
\hline \multirow[t]{2}{*}{67.6} & 215 & 32.5 & 103 & تغذية الحيوانات على علف البروتين الحيوانى (مخلفات المجازر والمسالخ) & 7 \\
\hline & & & & الممارسات غير الآمنة فى مجال رعاية الحيوانات : & ثالثا \\
\hline 69.1 & 220 & 30.8 & 98 & رعى الحيوان على مخلفات المنازل والقمامة خاصة الأغنام والماعز & 1 \\
\hline 72.3 & 230 & 27.4 & 88 & رعى الحيوانات على حواف الترع والمصارف الزراعية & 2 \\
\hline 49.6 & 158 & 41.8 & 133 & الإستخدام غير الصحيح لمضادات الطفيليات عند العلاج & 3 \\
\hline 51.2 & 163 & 48.7 & 155 & عدم الإلتزام بمواعيد التحصين ضد الأمراض الوبائية & 4 \\
\hline 67.9 & 216 & 32.1 & 102 & إستخدام مياه الترع والمصارف كمصادر لشرب الحيوان & 5 \\
\hline 83.9 & 267 & 16.1 & 51 & الاستعانة بطلوقة واحدة لتلقيح الماثية دون التأكل من مناسبته و سلامته & 6 \\
\hline 37.4 & 119 & 62.6 & 199 & علدم الإهتمام بالر عاية الصحية للإناث العشار & 7 \\
\hline 37.4 & 119 & 62.6 & 199 & التدخل غير الصحيح فى توليد الحيوان9- & 8 \\
\hline 45.5 & 145 & 54.1 & 172 & العلاج غير السليم فى حالات إلتهاب الضع & 9 \\
\hline \multirow[t]{2}{*}{77.3} & 246 & 22.6 & 72 & استعمال مصدر مياه عمومى لشرب الحيون دون التأكد من نظافته & 10 \\
\hline & & & & الممارسات غير الآمنة فى مجال السلامة الصحية والحفاظ على البيئة : & رابعا \\
\hline 80.1 & 255 & 19.8 & 63 & تنظيف الحيوان فى الترع والمصارف وخاصة الأغنام & 1 \\
\hline 72.3 & 230 & 27.7 & 88 & إستخدام فوارغ الكيماويات الزراعية فى شرب وتغذية الحيوان & 2 \\
\hline 87.4 & 278 & 12.6 & 40 & تجميع أكوام الروث بالقرب من حظائر الحيوان والمنازل & 3 \\
\hline 90.8 & 289 & 9.1 & 29 & إستعمال عربات نقل المحاصيل الزراعية فى رمى مخلفات الولادة والحيوانات النافقة & 4 \\
\hline 74.2 & 236 & 25.8 & 82 & حرق مخلفات الإنتاج الحيوانى & 5 \\
\hline 69.8 & 222 & 30.2 & 96 & تنظيف الحيوانات المصابة بالحمى القلاعية فى مياه الترع & 6 \\
\hline 85.2 & 271 & 14.8 & 47 & رمى مخلفات الولادة والإجهاض فى المجارى المائية & 7 \\
\hline
\end{tabular}

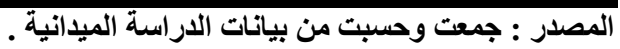

جدول رقم 4. درجة معرفة الزراع - المبحوثين - بالممارسات غير الآمنة في مجال الإنتاج الداجنى

\begin{tabular}{|c|c|c|c|c|c|}
\hline \multicolumn{4}{|c|}{ فئات المعرفة } & \multirow{3}{*}{ الممارسات غير الآمنة } & \multirow{3}{*}{ s } \\
\hline \multicolumn{2}{|c|}{ ل الا يعرف } & \multicolumn{2}{|c|}{ 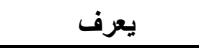 } & & \\
\hline$\%$ & $\dot{~}$ & $\%$ & $\dot{~}$ & & \\
\hline & & & & الممارسات غير الآمنة فى مجال تربية الطيور : & أولا \\
\hline 93.1 & 296 & 6.9 & 22 & ترك الإضاءة الإصطناعية المستمرة ليل نهار للتدفئة & 1 \\
\hline 98.7 & 314 & 1.3 & 4 & علم توفير أماكن مرتفعة ليلا لمبيت الطيور خاصة دجاج البيض المربى على الأرض & 2 \\
\hline 54.1 & 172 & 45.9 & 146 & عدم مراعاة التهوية الجيدة لحظائر الطيور & 3 \\
\hline 92.4 & 294 & 7.5 & 24 & علم توفير مصائد لوضع البيض فى حالة التربية الأرضية & 4 \\
\hline $\mathbf{8 6 . 2}$ & 274 & 13.8 & 44 & عدم تطبيق شروط الأمان الحيوى فى التربية المنزلية للطيور & 5 \\
\hline 95.3 & 303 & 4.7 & 15 & الجمع فى التربية بين الدجاج البلاى والمحسن فى مكان واحـ & 6 \\
\hline
\end{tabular}


Unsafe practices in animals and poultry production in rural areas of Menuofia ....

\begin{tabular}{|c|c|c|c|c|c|}
\hline 79.2 & 252 & 20.8 & 66 & عدم الإهتمام بتدفئة الأماكن المربى بها الطيور فى فصل الثتاء وعزل الأسقف فى فصل الصيف & 7 \\
\hline 87.1 & 277 & 12.9 & 41 & تربية الطيور في أماكن ذات حوائط بها شقوق وغير ملساء مع عدم طلايها بالجير & 8 \\
\hline \multirow[t]{2}{*}{88.9} & 283 & 11 & 35 & علدم مراعة الحجر الصحى عند شراء طيور جليدة لتربيتها & 9 \\
\hline & & & & الممارسات غير الآمنة فى مجال تغذية الطيور: & ثثانيا \\
\hline 97.2 & 309 & 2.8 & 9 & إضافة الزيوت والدهون الفاسدة الى علائق دجاج التسمين & 1 \\
\hline $\mathbf{9 7 . 2}$ & 309 & 2.8 & 9 & إستخدام مركزات البروتين الحيوانى الغير مطابق للمواصفات الفنية فى العلائق & 2 \\
\hline 95.3 & 303 & 4.7 & 15 & تغذية دجاج إنتاج البيض على حبوب الثعير بدلا من حبوب الذرة & 3 \\
\hline 94.9 & 302 & 5.1 & 16 & تغذية الطيور على بقايا الطعام ومخلفات الخضار والفاكهة التالفة & 4 \\
\hline 75.2 & 239 & 24.8 & 79 & إضافة بعض الهرمونات لعلاثق الطيور & 5 \\
\hline \multirow[t]{2}{*}{75.2} & 239 & 24.8 & 79 & عدم مراعاة شراء مخاليط العلائق من مصادر موثوق فيها وذات سمعة جيدة & 6 \\
\hline & & & & الممارسات غير الآمنة فى مجال رعاية الطيور : & ثالثا \\
\hline 91.1 & 291 & 8.5 & 27 & العشوائية فى الكميات المستخدمة من المضادات الحيوانية فى العلائق والثرب & 1 \\
\hline 69.8 & 222 & 30.2 & 96 & استخدام مضادات حيوية غير مسموح بها فى تحصين الطيور & 2 \\
\hline 83.6 & 266 & 16.4 & 52 & ترك الطيور تسبح فى مياه الترع والمستنقعات الملوثة بمياه الصرف الصحى & 3 \\
\hline 57.5 & 183 & 42.5 & 135 & عدم الإهتمام بالتحصينات الاورية للطيور & 4 \\
\hline 69.8 & 222 & 30.2 & 96 & عدم عزل الطيور المصابة بمكان منفصل & 5 \\
\hline \multirow[t]{2}{*}{68.9} & 219 & 31.1 & 99 & عدم الإهتمام بغسيل وتطهير أوانى شرب الطيور & 6 \\
\hline & & & & الممارسات غير الآمنة فى مجال السلامة الصحية والحفاظ على البيئة : & رابعا \\
\hline 97.8 & 311 & 2.2 & 7 & بيع وذبح الطيور دون الإلتزام بفترة سحب المضاد الحيوى من جسم الطائر & 1 \\
\hline 88.9 & 283 & 11 & 35 & التعامل المباشر مع الطيور المصابة دون مراعاة إحتياطات السلامة & 2 \\
\hline 93.7 & 298 & 3.3 & 20 & ترك الأولاد يلعبون مع الطيور باستمرار & 3 \\
\hline 70.1 & 223 & 29.9 & 95 & التخلص غير الآمن من بقايا ذبح الطيور والنافق منها & 4 \\
\hline 76.7 & 244 & 23.3 & 74 & ذبح الطيور التى تظهر عليها أعراض مرضية واستهلاكها دون إستثارة الطبيب البيطرى & 5 \\
\hline 86.4 & 275 & 13.6 & 43 & تخزين البيض خارج الثلاجات لمدة تزيد عن أسبوع صيفا وأسبوعين شتاءا & 6 \\
\hline 91.2 & 290 & 8.8 & 28 & تربية وذبح الطيور مع الأسر فى المنازل & 7 \\
\hline 86.2 & 274 & 13.8 & 44 & لدخول أماكن تربية الطيور دون الإلتزام باشتراطات السلامة اللازمة & 8 \\
\hline 83.1 & 264 & 16.9 & 54 & عدم الوعى بسلامة الطائر بعد ذبحه وصلاحيته للاستهلاك الآدمى & 9 \\
\hline
\end{tabular}

المصدر : جمعت وحسبت من بيانات الدراسة الميدانية

أن 1.8\% فقط من المبحوثين كاتت درجة معرفتهم

مرتفعة. وبصفة عامة فإن النتائج تشير إلى من إنى

انخفاض درجة المعرفة بالممارسات غير الآمنة

لاى الغالبية العظمى من المبحوثين بعينة الدراسة

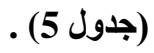

ثانيا : درجة تطبيق الزراع للممارسات غير الآمنة

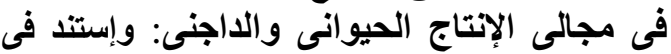
قياسه بسؤال المبحوث عن معرفتة ودرايته بثانلاثين والثين

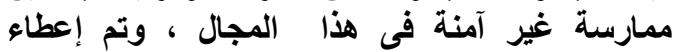

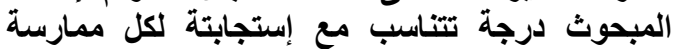

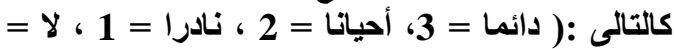

الأولاد يلعبون مع الطيور باستمرار، ولقد بلغت

النسب المئوية للزراع الذين يعرفون تلكاع

الممارسات غير الأمنة كما يلى :1.3\% ، 2.2\%

\%2.8\% ، 2.8، 3.3\% على الترتيب. وبتوزيع

المبحوثين وفقاً للارجة الكلية لمعرفة الممارسات

غير الآمنة فى مجالى الإنتاج الحيوانى والداجنى يتبين إنخفاض درجة المعرفة بالممارسات غير الإهى الآمنة لاى 75.5\% من المبحوثين، 22.9\% من المبحوثين كاتت درجة معرفتهم متوسطة ، في حين 
F.A. Salama, et al.,

فى رمى مخلفات الولادة والحيو انـات النافقة ، تنظيف

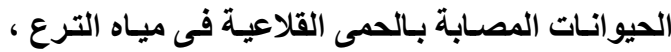
التظذيـة على الحبـوب بثـكل مباثـر دون اجراء أيسه

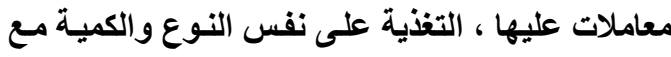
إختلاف نوع الحيوان وسنه ، ولقد بلغت النسب المئوية

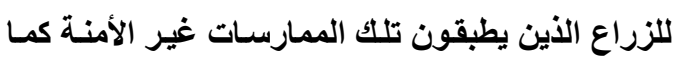

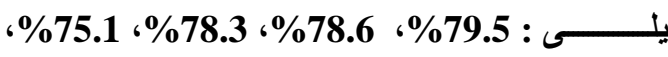
74.5 على الترتيب ، بينمـا كاتت أقل الممارسـات غير الأمنـة من حيث درجة تطبيق الزراع المبحوثين

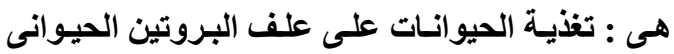
(مخلفات المجازر و المسالخ) بنسبة 8.4\%.
0). وجُمت الدرجات التي حصل عليها المبحوث في بئ

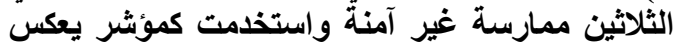

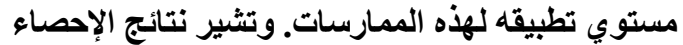
الوصفي لمتغير درجة المعرفة بالممارسات غير المير الآمنة،

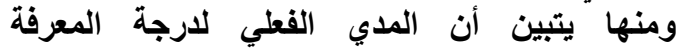
بالممارسات غير الآمنة قد تراوحت بين 3 - 90 بـ 90 درجة،

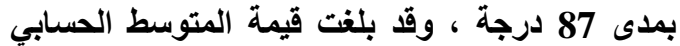
51.04 درجة، والاتحراف المعياري 0.74 درجة. أ) درجة تطبيق الزراع للممارسـات غير الآمنـة فى مجـال الإنتاج الحيوانى : وفيمـا يختص بتطبيتق الممارسـات غير الآمنة يلاحظ من خلال جدول (6) والخاصة بتباين

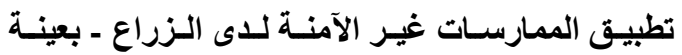

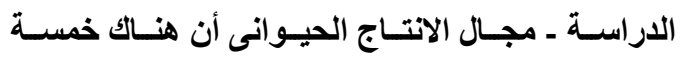

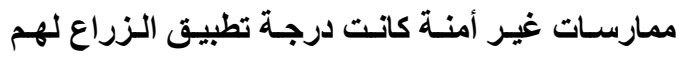
مرتفعة وهم : إستعمال عربات نقل المحاصيل الزراعية

جدول 5. توزيع المبحوثين إلى فئات وفقاً لارجة المعرفة بالممارسات غير الآمنة

\begin{tabular}{|c|c|c|}
\hline$\%$ & عدد المبحوثين & فئات درجة المعرفة بالممارسات غير الآمنة \\
\hline 75.5 & 240 & منخفض (60 - 80 درجة) \\
\hline 22.9 & 73 & متوسط (81- 100 درجة) \\
\hline 1.8 & 6 & مرتفع (101- 120 درجة) \\
\hline 100 & 318 & المجموع \\
\hline
\end{tabular}

المصدر : جمعت وحسبت من بيانات الاراسة الميدانية المئية

جدول 6. درجة تطبيق الزراع بالممارسات غير ألآنة فئ في مجال الإنتاج الحيوانى

\begin{tabular}{|c|c|c|c|c|c|c|c|c|c|c|}
\hline \multirow{2}{*}{\multicolumn{2}{|c|}{ لا لايطبق }} & \multicolumn{8}{|c|}{ بطبق } & \multirow[t]{3}{*}{ الممارسـات غير الآمنة } \\
\hline & & \multicolumn{2}{|c|}{ المجموع } & \multicolumn{2}{|c|}{ نادرا } & \multicolumn{2}{|c|}{ أحيانا } & \multicolumn{2}{|c|}{ غالبا } & \\
\hline$\%$ & ن ن & $\%$ & ن ن & $\%$ & ن ن & $\%$ & ن & $\%$ & $\dot{ن}$ & \\
\hline & & & & & & & & & & أولا : الممارسات غير الآمنة فى مجال تربية الحيوانات \\
\hline 81.1 & 258 & 18.5 & 60 & 2.2 & 7 & 16.7 & 53 & $\mathbf{0}$ & $\mathbf{0}$ & 1. ذبح إناث الماشية فى الأعمار الصغيرة \\
\hline$\overline{24.8}$ & 79 & 75.2 & 239 & 3.8 & 12 & $\overline{67.9}$ & 216 & 3.5 & 11 & 2. البيع الجائر للعجلات الإناث الصغيرة حليثى الولادة \\
\hline 80.8 & 275 & 13.5 & 43 & 3.5 & 11 & 14.8 & 47 & 0.9 & 3 & 3. إستخدام حيوان إنتاج اللبن فى العمل لفترات طويلة \\
\hline 38.4 & 122 & 61.6 & 196 & 29.2 & 98 & 30.2 & 96 & 1.6 & 5 & 4. تسكين العجول الرضيعة في حظائر جماعية بعد الولادة \\
\hline 79.2 & 252 & 20.7 & 66 & 1.9 & 6 & $\mathbf{1 7 . 3}$ & 55 & 1.6 & 5 & 5. وضع الحيوان المصاب مع الحيو انات السليمة في مكان واحد \\
\hline 81.4 & 259 & 18.5 & 59 & 4.4 & 14 & 8.8 & 28 & 5.3 & 17 & 6. عدم الاهتمام بتطهير حظائر الحيوان بصفة دورية \\
\hline & & & & & & & & & & ثانيا : الممارسات غير الآمنة فى مجال تغذية الحيوانات \\
\hline 25.2 & 81 & 74.5 & 237 & 4.4 & 14 & 55.3 & 176 & 14.2 & 47 & 1. التذذية على نفس النوع و الكمية مع إختلاف نوع الحيوان وسنه \\
\hline 44.3 & 141 & 55.6 & 177 & 3.1 & 10 & 45.3 & 144 & 7.2 & 23 & 2. تقايم الأعلاف بإلقائها مباشرة على الأرض \\
\hline 35.5 & 112 & 64.7 & 206 & 8.2 & 26 & 52.5 & 167 & 4.1 & 13 & 3. وضع الأعلاف بالقرب من أماكن الشرب \\
\hline 21.7 & 69 & 78.3 & 249 & 21.7 & 69 & 54.5 & 173 & 2.2 & 7 & 4.التغذية على الحبوب بشكل مباشر دون اجراء أيه معاملات عليها \\
\hline$\overline{52.5}$ & 174 & 21.6 & 69 & 4.1 & 13 & 33.3 & 106 & 8.5 & 27 & 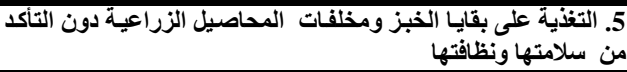 \\
\hline $\begin{array}{ll}78.3 \\
\end{array}$ & 249 & 21.6 & 69 & 3.1 & 10 & $\mathbf{1 7 . 0}$ & 54 & 1.6 & 5 & 6. تغذية الحيوان على البرسيم غير الناضج وغير الجاف \\
\hline 78.3 & 249 & 21.6 & 69 & 3.1 & 10 & $\mathbf{1 7 . 0}$ & 54 & 1.6 & 5 & و المستخائخ) الحيوانـات على علف البروتين الحيوانى(مخلفـات المجـازر \\
\hline
\end{tabular}


F.A. Salama, et al.,

\begin{tabular}{|c|c|c|c|c|c|c|c|c|c|c|}
\hline & & & & & & & & & & ثنالثا : الممارسات غير الآمنة فى مجال رعاية الحيوانات \\
\hline 69.8 & 222 & 30.2 & 96 & 2.2 & 7 & 25.8 & 82 & 2.2 & 7 & ل الحيوان على مخلفات المنازل و القمامة خاصة الأغنام و الماعز \\
\hline 69.8 & 222 & 30.2 & 96 & 7.2 & 23 & 22.6 & 72 & 0.3 & 1 & 2. رعى الحيوانات على حواف الترع والمصارف الزراعية \\
\hline 86.2 & 274 & 13.8 & 44 & 2.2 & 7 & 9.7 & 31 & 1.6 & 6 & 3. الإستخذام غير الصحيح لمضادات الطفيليات غذد العلاج \\
\hline 85.8 & 273 & 14.2 & 45 & 3.1 & 10 & 10.4 & 33 & 0.6 & 2 & 4. عدم الإلتزام بمواعيد التحصين ضد الأمراض الوبائية \\
\hline 66.0 & 210 & 33.9 & 108 & 4.7 & 15 & 23.9 & 76 & 5.3 & 17 & 5. إستخذام مياه الترع والمصارف كمصادر لثرب الحيوان \\
\hline 21.4 & 68 & 78.6 & 250 & 4.1 & 13 & 42.8 & 136 & 31.8 & 101 & 6.الاستعاتة بطلوقة واحدة لتلقيح الماشية دون التأكد من مناسبتّه وسلامتّه \\
\hline 88.7 & 282 & 11.3 & 36 & 2.5 & 8 & 6.0 & 19 & 2.8 & 9 & 7. عل عام الإهتمام بالرعاية الصحية للإناث العشار \\
\hline 88.1 & 280 & 11.9 & 38 & 1.6 & 5 & 9.4 & 30 & 0.9 & 3 & 8. التخل غير الصحيح فى توليد الحيوان \\
\hline 91.8 & 282 & 11.3 & 36 & 1.9 & 6 & 5.7 & 18 & 0.6 & 2 & 9. العلاج غير السليم فى حالات إلتهاب الضرع \\
\hline 52.2 & 166 & 47.8 & 152 & 166 & 8 & 34.0 & 108 & $\mathbf{1 1 . 3}$ & 36 & ـ استعمال مصدر مياه عمومى لشرب الحيون دون التأكد من نظافته \\
\hline & & & & & & & & & & رابعا: الممارسات غير الآمنة فى مجال السلامة الصحية ونظافة البيئة: \\
\hline 34.0 & 108 & 66.0 & 210 & 10.1 & 32 & 49.7 & 139 & 12.2 & 39 & 1. تنظيف الحيوان فى الترع والمصارف وخاصة الأغنام \\
\hline 61.9 & 197 & 38.1 & 121 & 3.8 & 12 & 29.2 & 93 & 5.0 & 16 & إستخذام فوارغ الكيماويات الزراعية فى شرب وتغذية الحيوان \\
\hline 19.2 & 61 & 80.8 & 275 & 2.2 & 7 & 29.9 & 95 & 48.4 & 155 & 3. تجميع أكوام الروث بالقرب من حظائر الحيوان والمنازل \\
\hline 20.4 & 65 & 79.6 & 253 & 1.3 & 4 & 41.4 & 131 & 37.1 & 118 & و الحيو إنتعات النافقة عربات نقل المحاصيل الزراعية فى رمى مخلفات الولادة \\
\hline 89.3 & 284 & 10.7 & 34 & 0.9 & 3 & 8.5 & 27 & 1.3 & 4 & 5. حرق مخلفات الإنتاج الحيوانى \\
\hline 30.8 & 98 & 69.2 & 220 & $\mathbf{1 1 . 0}$ & 35 & 55.0 & 175 & 3.1 & 10 & تنظيف الحيوانات المصابة بالحمى القلاعية فى مياه الترع \\
\hline 26.1 & 83 & 73.8 & 235 & 1.9 & 6 & 26.7 & 85 & 45.3 & 144 & رمى مخلفات الولادة والإجهاض فى المجارى المائية \\
\hline
\end{tabular}

المصدر : جمعت وحسبت من بيانات الاراسة الميدانية .

متوسط للتطبيق، و 18.6\% من المبحوثين ذوى

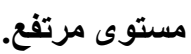

ثالثا: العلاقة بين درجة معرفة وتطبيق الزراع للممارسات غير الآمنة في مجالي الإنتاج الحيواني

والداجنى وكل من المتغيرات المستقلة المدروسة الإنياجة

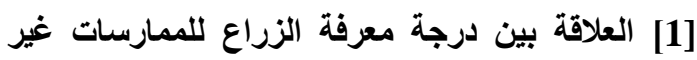
الآمنة وكل من المتغيرات المستقلة

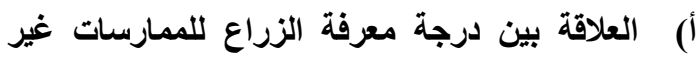

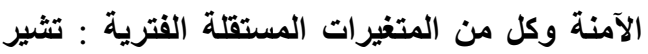

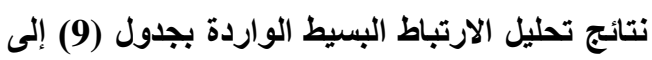

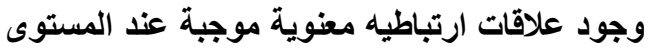

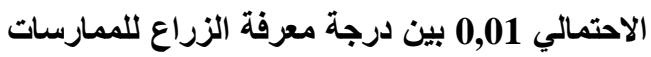

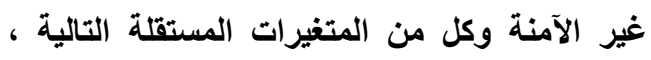

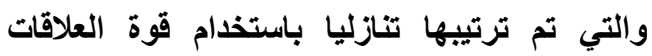

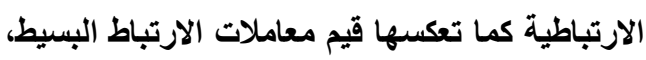
وهي: درجة معارف المبحوث المرتبطة بالإنتاج

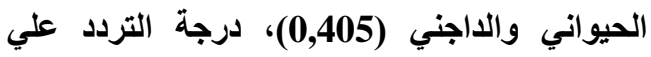
وكلاء التغيير (0,324)، الاتجاه البيئي (0,275)،

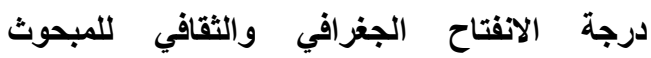
(0,241)، مستوى تعليم المبحوث (0,218) ، الجاه المبحوث نحو التجديدية في مجالي الانتاج الحيواني
ب) درجة تطبيق الزراع للممارسات غير الآمنة فى مجال الإنتاج الداجنى : وفيما يختص بتطبيق المبارئ المارسات

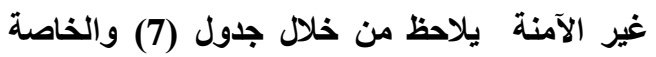
بتباين تطبيق الممارسات غير الآمنة لدى الزراع - الاعل

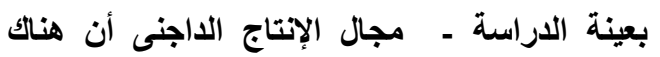

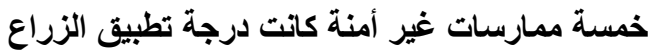
لهم مرتفعة وهم : الجمع فى التربية بين الاجاج البلاى والمحسن فى مكان واحد ، ترك الأولاد يلعبون

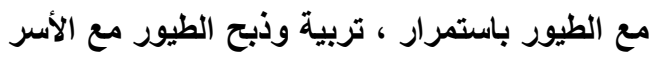

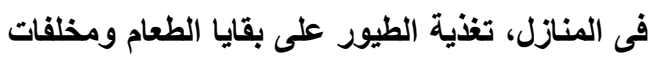

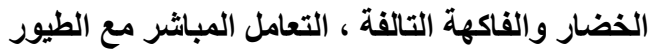

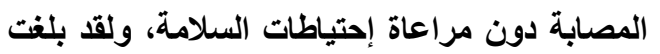
النسب المئوية للزراع الذين يطبقون تلك الممارسات

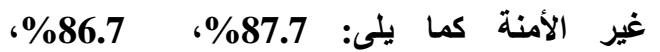

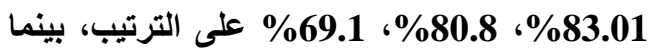
كاتت أقل الممارسات غير الأمنة من حيث درجة الترتي

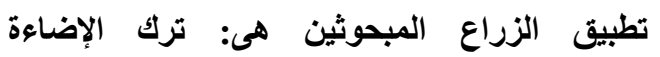
الإصطناعية المستمرة ليل نهار للتدفئة بنسبة

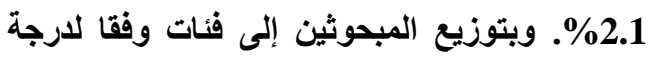
التطبيق للممارسات غير الآمنة جدول (8) تبين أن

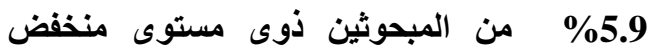
للتطبيق ، 75.4\% من المبحوثين ذوى مستوى دوى منفئوى 
F.A. Salama, et al.,

الزراع للممارسات غير الآمنة ، وأثارت نتائج الاراسة إلى وجود فروق معنوية بين الممتهنين بمهن مرتبطة بالزراعة والممتهنين بمهن غير بروني

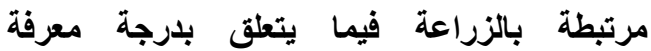
الممارسات غير الآمنة ، مما يغنى أن هذا المتغير لهاته تأثير في درجة معرفة الزراع للممارسات غير الآمنة الآنة

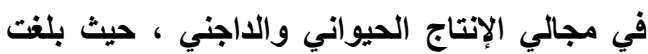
\%3.1 للمبحوث ، أظهرت نتائج تحليل التباين أحادي الاتجاه و One-Way Anova وجود فروق معنوية في درجة معرفة الزراع

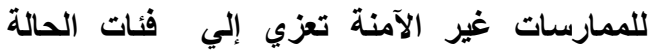
الزواجية للمبحوثين بعينة الدراسة ، كما أظهرت النتائج عدم وجود فروق معنوية بين فئات متغير نوعية العمالة بالمزرعة فيما يتعلق بدرجة معرفة فئة

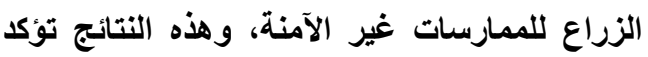
علي أن المتغيرين (الحالة الزواجية، ونوعية العمالة

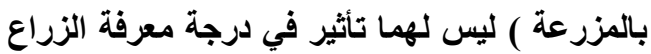
للممارسات غير الآمنة في مجالي الإنتاج الحيواني

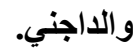

والداجني (0,199))، درجة الثقة في الأجهزة الحكومية (0,197)، درجة التردد علي المراكز

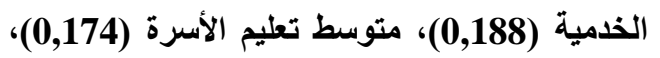

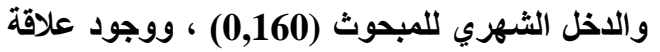
ارتباطيه معنوية موجبة عند المستوى الاحتمالي 0,05 بين درجة معرفة الزراع للممارسات غيرة الاحتير

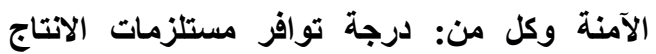

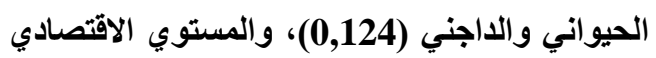
والمعيثي للأسرة (0,117).

كما أوضحت النتائج أن جميع العلاقات بين المتغيرات المستقلة سالفة الذكر، والتي ثبت معنوياتها والمتغير التهات

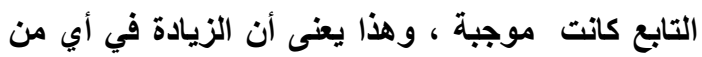

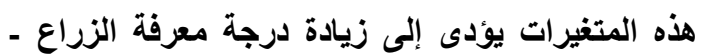
بعينة الاراسة ـ للممارسات غير الآمنة في مجالي الانتاج الحيو اني و الداجني. ب) العلاقة بين درجة معرفة الزراع للممارسات غير الآمنة

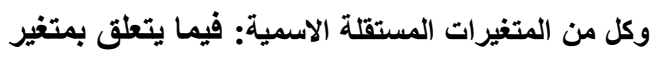

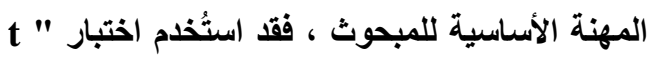

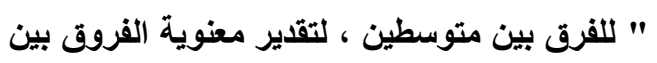

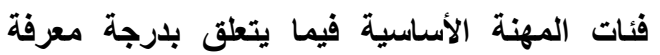

جدول 7. درجة تطبيق الزراع بالممارسات غير الآمنة في مجال الإنتاج الداجنى

\begin{tabular}{|c|c|c|c|c|c|c|c|c|c|c|}
\hline \multirow{2}{*}{\multicolumn{2}{|c|}{ لا لاطبق }} & \multicolumn{8}{|c|}{ يطبق } & \multirow[t]{3}{*}{ الممارسات غير الآمنة } \\
\hline & & \multicolumn{2}{|c|}{ 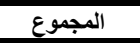 } & \multicolumn{2}{|c|}{ نادرا } & \multicolumn{2}{|c|}{ أحيانا } & \multicolumn{2}{|c|}{ غالبا } & \\
\hline$\%$ & $\dot{ن}$ & $\%$ & ن & $\%$ & $\dot{ن}$ & $\%$ & $\dot{ن}$ & $\%$ & $\dot{ن}$ & \\
\hline & & & & & & & & & & أولا : الممارسات غير الآمنة فى مجال تربية الطيور \\
\hline 76.4 & 243 & 23.5 & 75 & 5.0 & 16 & 18.8 & 58 & 0.3 & 1 & 1. ترك الإضاءة الإصطناعية المستمرة ليل نهار للتدفئة \\
\hline 95.9 & 305 & 4.2 & 13 & 0.3 & 1 & 1.9 & 6 & 1.9 & 6 & 2. علد توفير أماكن مرتفعة ليلا لمبيت الطيور خاصة دجاج البيض المربى على الأرض \\
\hline 92.5 & 294 & 7.5 & 24 & 0.6 & 2 & 6.9 & 22 & $\mathbf{0}$ & $\mathbf{0}$ & 3. عدم مراعاة التهوية الجيدة لحظائر الطيور \\
\hline$\overline{71.7}$ & 228 & 28.3 & 90 & 2.8 & 9 & 24.2 & 77 & 1.9 & 4 & 4. عدم توفير مصائد لوضع البيض فى حالئة التربية الأرضية \\
\hline 74.5 & 237 & 25.4 & 81 & 3.8 & 4 & 17.0 & 54 & 4.7 & 15 & 5. عدم تطبيق شروط الأمان الحيوى فُى التربية المنزلية للطيور \\
\hline 12.3 & 39 & 87.7 & 279 & 1.9 & 6 & 49.1 & 156 & 36.8 & 117 & 6. الجمع فى التربية بين الدجاج البلاى و المحسن فى مكان واحد \\
\hline 89.0 & 283 & 11.0 & 35 & 1.3 & 4 & 8.5 & 27 & 1.3 & 4 & 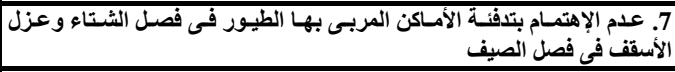 \\
\hline 53.1 & 169 & 46.8 & 149 & 3.5 & 11 & 39.0 & 124 & 4.4 & 14 & 8. تربية الطيور فى أماكن ذات حوانط بها شقوق وغير ملساء مع عدم طلائها بالجير \\
\hline 52.2 & 166 & 47.8 & 152 & 4.7 & 15 & 39.3 & 127 & 3.1 & 10 & 9. عدم مراعة الحجر الصحى عند شراء طيور جديدة لتربيتها \\
\hline & & & & & & & & & & ثانيا : الممارسات غير الآمنة فى مجال تظذية الطيور \\
\hline 90.3 & 287 & 9.7 & 31 & 4.1 & 13 & 5.3 & 17 & 0.3 & 1 & 1. إضافة الزيوت والدهون الفاسدة الى علانق دجاج التسمين \\
\hline 93.4 & 297 & 6.6 & 21 & 3.1 & 10 & 1.9 & 6 & 1.6 & 5 & 2. إستخام مركزات البروتين الحيو انى الغير مطابق للمواصفات الفنية فى العلانق \\
\hline 32.4 & 103 & 67.6 & 215 & 21.4 & 68 & 44.3 & 141 & 1.9 & 6 & 3. تظذية دجاج إنتاج البيض على حبوب الثعبر بلالا من حبوب الذرة \\
\hline$\overline{19.2}$ & 61 & 80.8 & 257 & $\overline{1.3}$ & 6 & $\overline{50.9}$ & 162 & 28.6 & 91 & 4. تظذية الطيور على بقايا الطعام ومخلفات الخضار و الفاكهة التالفة \\
\hline 73.9 & 235 & 26.1 & 83 & 3.0 & 6 & 23.0 & 73 & $\mathbf{0}$ & $\mathbf{0}$ & 5. إضافة بعض الهرمونات لعلائق الطيور \\
\hline 90.6 & 288 & 9.4 & 30 & $\overline{1.6}$ & 5 & 5.7 & 18 & 2.2 & 7 & 6. عدم مر اعاة شراء مخاليط العلائق من مصادر موثُوق فيها وذات سمعة جيدة \\
\hline
\end{tabular}


F.A. Salama, et al.,

\begin{tabular}{|c|c|c|c|c|c|c|c|c|c|c|}
\hline & & & & & & & & & & لثالثا : الممارسات غير الآمنة فى مجال رعاية الطيور \\
\hline 89.3 & 284 & 10.6 & 34 & 4.7 & 15 & 5.7 & 18 & 0.3 & 1 & 1. العشو ائية فى الكميات المستخدمة من المضادات الحيوانية فى العلاثق و الثرب \\
\hline 82.1 & 261 & $\mathbf{1 7 . 9}$ & 57 & 2.2 & 7 & 14.5 & 46 & $\overline{1.3}$ & 4 & 2. استخذام مضادات حيويةٌ غير مسموح بها فى تحصين الطيور \\
\hline 33.6 & 107 & 66.2 & 211 & 9.4 & 30 & 46.2 & 147 & 10.7 & 34 & 3. ترك الطيور تسبح فى مياه الترع والمستنقعات الملوثة بمياه الصرف الصحى \\
\hline 51.9 & 165 & 48.1 & 153 & 19.2 & 18 & 28.0 & 89 & 0.9 & 3 & 4. عدم الإهتمام بالتحصينات الدورية للطيور \\
\hline 87.7 & 279 & 12.2 & 39 & 1.9 & 2 & 6.6 & 21 & 8.3 & 12 & 5. عدم عزل الطيور المصابة بمكان منفصل \\
\hline 85.8 & 273 & 14.2 & 45 & $\overline{4.1}$ & 5 & 6.3 & 20 & 3.8 & $\overline{12}$ & 6. علم الإهتمام بغسيل وتطهيز أوانى شرب الطيور \\
\hline & & & & & & & & & & رابعا: الممارسات غير الآمنة فى مجال السلامة الصحية ونظافة البيئة: \\
\hline 62.3 & 198 & 37.3 & 120 & 2.2 & 7 & 34.0 & 108 & 1.6 & 5 & 1. بيع وذبح الطيور دون الإلتزام بفترة سحب المضاد الحيوى من جسم الطائر \\
\hline 30.8 & 98 & 69.2 & 220 & $\overline{1.6}$ & 5 & 49.1 & 156 & 18.6 & 59 & 2. التعامل المباشر مع الطيور المصابة دون مراعاة إحتياطات السلامة \\
\hline 13.2 & 42 & 86.7 & 276 & 1.9 & 15 & 58.2 & 185 & 26.4 & 85 & 3. ترك الأو لاد يلعبون مع الطيور باستمرار \\
\hline 87.0 & 248 & 22.0 & 70 & 5.7 & 15 & 16.0 & 51 & $\overline{0.3}$ & 1 & 4. التخلص غير الآمن من بقايا ذبح الطيور والنافق منها \\
\hline 51.5 & 163 & 48.7 & 155 & 4.7 & 61 & 39.9 & 127 & 4.1 & 13 & 5. ذالطبي البيطرى الطيور التى تظهر عليها أعراض مرضية واستهلاكها دون إستثـارة \\
\hline 36.5 & 116 & 63.5 & 202 & 0.6 & 13 & 15.4 & 49 & 47.5 & 151 & 6. تخزين البيض خارج الثلاجات لمدة تزيد عن أسبوع صيفا وأسبوعين شتاءا \\
\hline 17.0 & 54 & 83.0 & 264 & 3.8 & 12 & 459 & 146 & 33.3 & 106 & 7. تربية وذبح الطيور مع الأسر فى المنازل \\
\hline 34.9 & 111 & 65.1 & 207 & 7.2 & 23 & 37.4 & 119 & 20.4 & 65 & 8. دخول أماكن تربية الطيور دون الإلتزام باشتراطات السلامة اللازمة \\
\hline 56.5 & 181 & 43.5 & 137 & 4.7 & 10 & 38.4 & 122 & $\mathbf{0}$ & $\mathbf{0}$ & 9. عدم الوعى بسلامة الطائر بعد ذبحه وصلاحيته للاستهلاك الآدمى \\
\hline
\end{tabular}

المصدر : جمعت وحسبت من بيانات الاراسة الميدانية .

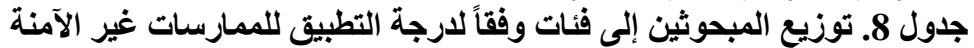

\begin{tabular}{|c|c|c|}
\hline$\%$ & علد المبحوثين & فئات درجة التطبيق للممارسات غير الآمنة \\
\hline 5.9 & 19 & منخفض (3 - 32 درجة) \\
\hline 75.4 & 240 & متوسط (33- 62 درجة) \\
\hline 18.6 & 59 & مرتفع (63- 90 درجة) \\
\hline 100 & 318 & المجموع \\
\hline
\end{tabular}

المصدر : جمعت وحسبت من بيانات الاراسة الميدانية. .

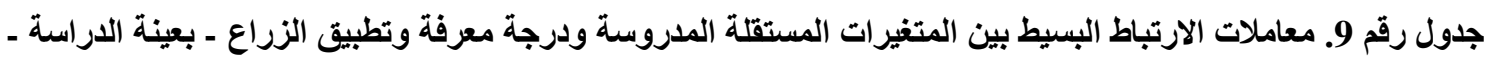

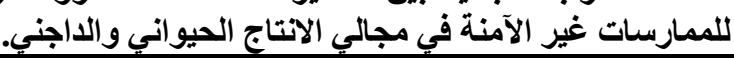

\begin{tabular}{|c|c|c|c|}
\hline $\begin{array}{c}\text { قيم معامل الإرتباط البسبيط) } \\
\text { (درجة التطبيق) }\end{array}$ & قيم معامل الإرتباط البسيط & المتغيرات المستقلة & م م \\
\hline 0.056 & 0.015- & عمر المبحوث & 1 \\
\hline$* * 0.191-$ & $* * 0.218$ & مستوى تعليم المبحوث & 2 \\
\hline $0.062-$ & $* * 0.160$ & الاخل الثهري للمبحوث & 3 \\
\hline 0.109- & $* * 0.241$ & الانفتاح الجغرافى والثقافي للمبحوث & 4 \\
\hline$* 0.118$ & 0.056- & الخبرة الوظيفية للمبحوث & 5 \\
\hline 0.073 & 0.071- & حجم الأسرة & 6 \\
\hline$* * 0.170$ & $* * 0.174$ & متوسط تعليم الأسرة & 7 \\
\hline *0.139 - & $* * 0.324$ & درجة التردد على وكلاء التغيير & 8 \\
\hline *0.136 - & **0.188 & لدرجة التردد على المراكز الخدمية & 9 \\
\hline $0.092-$ & **0.199 & إتجاه المبحوث نحو التجديدية & 10 \\
\hline 0.018 & 0.088 & اتجاه المبحوث نحو المشاركة التطوعية & 11 \\
\hline $0.011-$ & $* * 0.177$ & درجة ثقة المبحوث في الأجهزة الحكومية & 12 \\
\hline $0.077-$ & 0.015 & درجة الرضا المجتمعى المحلى & 13 \\
\hline$* * 0.219-$ & $* * 0.275$ & الإتجاه البيئى & 14 \\
\hline$* 0.100$ - & 0.058 & الرغبة فى الإقتراض & 15 \\
\hline 0.018 - & 0.071 & ديموقر اطية إتخاذ القرار & 16 \\
\hline
\end{tabular}




\begin{tabular}{|c|c|c|c|}
\hline $0.002-$ & $0.040-$ & درجة توافر أسواق الماشية والدواجن & 17 \\
\hline $0.013-$ & $* 0.124$ & درجة توافر مستلزمات الإتتاج الحيوانى والداجنى & 18 \\
\hline $0.010-$ & 0.109 & حجم الحيازة الحيوانية والاجنية & 19 \\
\hline 0.007 & $* 0.117$ & المستوى الإقتصادى والمعيشى للأسرة & 20 \\
\hline $0.077-$ & $0.030-$ & لدرجة الرضا عن جدوى تربية الحيوانات والطيور & 21 \\
\hline $0.271-$ & $* * 0.405$ & درجة معارف المبحوث المرتبطة بالإنتاج الحيوانى والاجنى & 22 \\
\hline$* * 0.275-$ & - & درجة معرفة الزراع بالممارسات غير الآمنة فى مجالى الإنتاج الحيوانى و الاجنى & 23 \\
\hline
\end{tabular}

المصدر: حسبت من بيانات الدراسة الميدانية باستخدام الحاسب الآلي .

الزراع - بعينة الدراسة ـ للممارسات غير الآمنة في

$$
\text { مجالي الانتاج الحيواني والاجني. }
$$

ب) العلاقة بين درجة تطبيق الزراع للممارسات غير الآمنة وكل من المتغيرات المستقلة الإسمية: فيما يتعلق بمتغير المهنة الأساسية للمبحوث، فقد استُخدم اختبار " t " للفرق بين متوسطين، لتقدير معنوية الفروق بين فئات المهنة الأساسية فيما يتعلق بدرجة تطبيق الزراع للممارسات غير الآمنة ، وأشارت النتائج إلى عدم وجود فروق معنوية بين الممتهنين بمهن مرتبطة بالزراعة والممتهنين بمهن غير

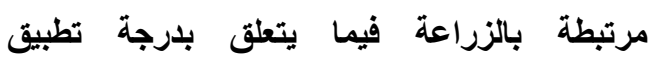
الممارسات غير الآمنة ، مما يعنى أن هذا المتغير ليس لله تأثثر في درجة تطبيث الزراع للممارسات غير الآمنة في مجالي الإنتاج الحيواني والاجني. وفيما يختص بمتغير الحالة الزواجية للمبحوث ، الزية ل One- أظهرت نتائج تحليل التباين أحادي الاتجاه Way Anova معنوية في درجة تطبيق الزراع للممارسات غير الآمنة تعزي إلي فئات الحالة الزواجية للمبحوثين بعينة الدراسة. كما أظهرث نتائج الدراسة عدم وجود فروق معنوية بين فئات متغير نوعية العمالة بالمزرعة فيما يتعلق بلدرجة تطبيق الزراع للممارسات غير الآمنة, وهذه النتائج تؤكد علي أن المتغيرين (الحالة الزواجية ، ونوعية العمالة بالمزرعة ) ليس لهما تأثير في درجة معرفة الزراع
[2] العلاقة بين درجة تطبيق الزراع للممارسات غير الآمنة وكل من المتغيرات المستقلة

أ) العلاقة بين درجة تطبيق الزراع للممارسات غير الآمنة وكل من المتغيرات المستقلة الفترية: تثير نتائج تحليل الارتباط البسيط الواردة بجدول (9) إلى وجود علاقة ارتباطيه معنوية موجبة عند المستوى الاحتمالي 0,05 بين درجة تطبيق الزراع للممارسات غير الآمنة ومتغير الخبرة الوظيفية للمبحوث (0.118) ، وهذا يعنى أن الإرتفاع فى متغير الخبرة الوظيفية للمبحوث سيؤدى

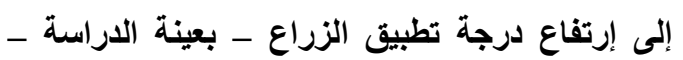
للممارسات غير الآمنة ـ كما تبين وجود علاقة أرتباطية عكسية عند المستوى الإحتمالى 0.01 بين درجة تطبيق الزراع للممارسات غير الآمنة وكل من المتغيرات المستقلة التالية، والتي تم ترتيبها تنازليا باستخدام قوة العلاقات الارتباطية كما تعكسها قيم معاملات الارتباط البسيط ، وهي: درجة معرفة المبحوث بالممارسات غير الآمنة (- 0.275)، ودرجة

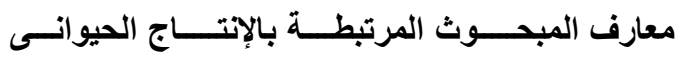
و الداجنـى (-0.271)، والإتجاه البيئى (- 0.219) ومستوى تعليم المبحوث (- 0.191) ، ومتوسط تعليم الأسرة (-0.170)، ووجود علاقة إرتباطية سالبة عند المستوى الإحتمالى 0.05 بين درجة تطبيق الزراع للممارسات غير الآمنة وكل من: درجة التردد على وكلاء التغيير (-0.139)، ودرجة التردد على المراكز الخدمية ( - 0.136) ، وهذا يعنى أن الإنخفاض في أي من هذه المتغيرات يؤدى إلى إرتفاع درجة تطبيق 
F.A. Salama, et al.,

0.01 ، وهذا يغنى أن هناك أربع متغيرات مستقلة ـ فترية ـ تؤثر في درجة معرفة الزراع بالممارسات

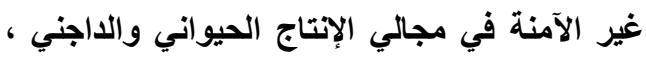

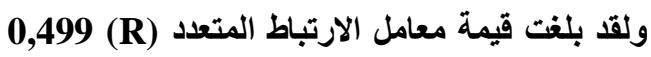
وقيمة معامل التحديد المعدل (Adjusted R²) قد بـ بلغت 0,240، مما يعنى أن المتغيرات المستقلة

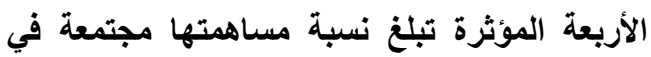
تفسير التباين الحادث في درجة معرفة الزراع

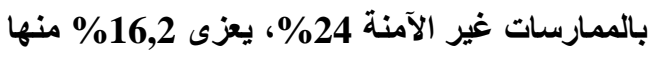
إلي متغير درجة معارف المبحوث المرتبطة بالاتتاج الحيواني والداجني ، 4,1\% إلي درجة تردد المبحوث علي وكلاء التغيير، 2,4\% إلي الاتجاه

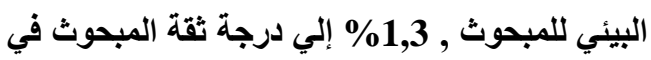
الأجهزة الحكومية. وبصفة عامة ، فإن النتائج تثشير

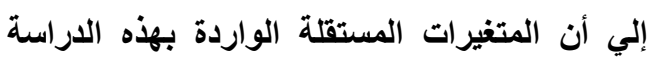
تسنطيع تفسير 27,1\% من التباين في درجة معرفة

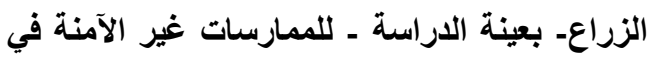
مجالي الإنتاج الحيواني والداجني، أما باقي النسبة لونية والتي تبلغ 72,9\% ترجع إلى متغيرات أخرى لم الماني

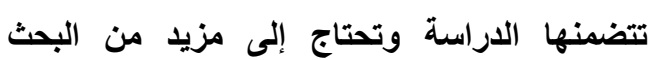

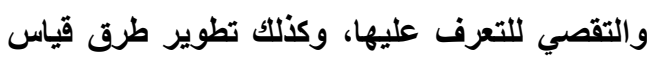

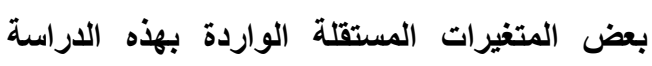
والذي من شأنه يزيد من قدرتها التفسيرية. وبناءً علي تلك النتائج يمكن رفض الفرض ئلئ من الإحصائي المتعلق بالفرض النظري الأول بالنسبة للمتفيرات

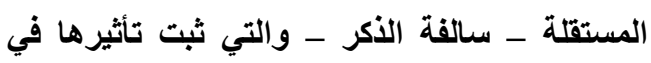

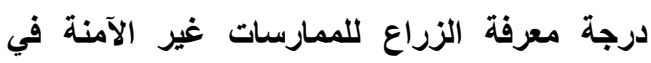

$$
\text { مجالي الإنتاج الحيو اني والداجني. }
$$

للممارسات غير الآمنة في مجالي الإنتاج الحيواني

$$
\text { والداجني. }
$$

رابعا: الأهمية النسبية للمتئيرات المستقلة العدروسة في تفسير التباين الحادث في درجة النية

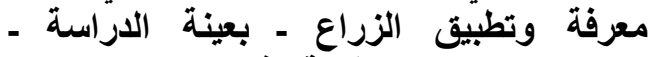
بالممارسات غير الآمنة في مجاعي الإني الإنتاج الحيواني والداجني : الإنيل [1] الأهمية النسبية للمتغيرات المستقلة المدروسة في تفسير التباين الحادث في درجة معرفة الزراع بعينة الدراسة - بالممارسات غير الآمنة في مجالي الإتتاج الحيواني والداجني: لتصديد المتغيرات المستقلة المؤثرة في درجة معرفة الزراع - بعينة الاراسةـ بالممارسات غير الآمنة في مجالي الإنتاج الحيواني والداجني، كان من الضروري اختبار الفرض النظري الأول والذي تم اختباره بالفرض الإحصائي التالي: لا تتأثر درجة معرفة الزراع بالممارسات غير الآمنة في مجالي الإتتاج الحيواني

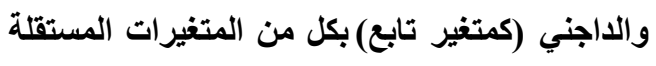
المدروسة، واستخدام نموذج التحليل الانحداري المتعدد المتدرج الصاعد "Step wise" هذا فيما فئيا يختص بالمتغيرات التي قيست بمقياس فتري "Interval Variables" Nominal " المستقلة التي قيست بمقياس اسمي Variables التقدير تأثير تلك المتغيرات: وتشير النتائج (Eta2) الواردة بجدول (10) إلى معنوية نموذج التحليل

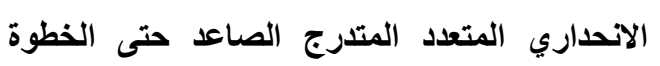

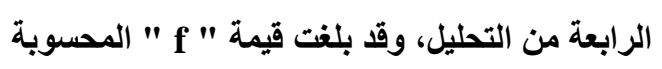
26,009 وهى معنوية على المستوى الاحتمالي

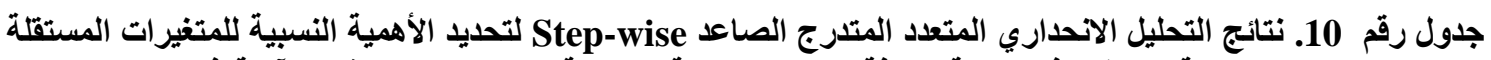

\begin{tabular}{|c|c|c|c|c|c|c|}
\hline & & & & & الحيواني و اللاجني. & \\
\hline قيمنوية معامل لاختبار & المتغير التابع فيع & $\begin{array}{c}\text { معامل التحدل } 1 \text { المعدل } \\
\text { (Adjusted ) } \\
\text { R }^{2}\end{array}$ & $\begin{array}{l}\text { التحعايد } \\
\text { (R²) }\end{array}$ & المتعدل الارتباط & المؤثرة في المتغير التتابع & خطيل \\
\hline$* * 62,159$ & $\% 16.2$ & 0.162 & 0.164 & 0.405 & درجة معارف المبحوث المرتبطة بالإتتاج & الخطوة الأولى \\
\hline
\end{tabular}

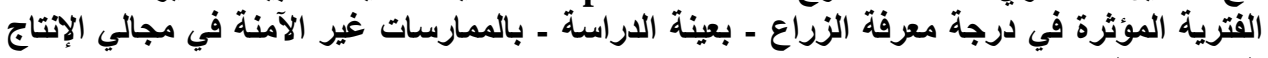


F.A. Salama, et al.,

\begin{tabular}{|l|l|l|l|r|r|}
\hline & & & & \\
\hline & & & & \\
\hline
\end{tabular}

المستقلة الخمس المؤثرة تبلغ نسبة مسـاهمتها مجتمعة في تفسير التباين الحادث في درجة تطبيق الزراع بالممارسـات

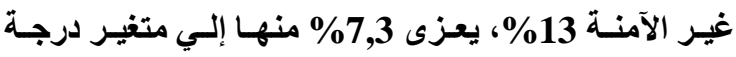
المعرفة بالممارسات غير الآمنة فى مجالى الاتتاج الحيواني والـاجني ، 2,7\% إلـي درجـة معسارف المبحوث المرتبطـة بالإنتــاج الحيـوانى والــاجنى ، 1,2\% إلـي الاتجـاه البيئسي للمبحـوث ، 1,1\% إلـي درجـة الرضــا المجتمعى المحلى، 0.9 \% إلى متوسط تعليم أسرة المبحوث.

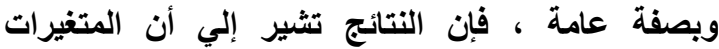

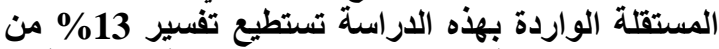

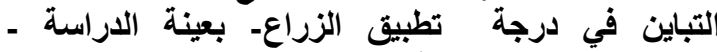
للممارسات غير الآمنة في في مجالي الإنتاج الحئ الحيواني

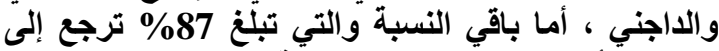

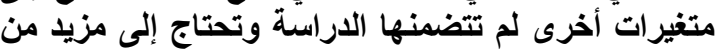

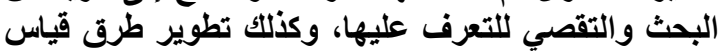

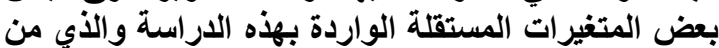

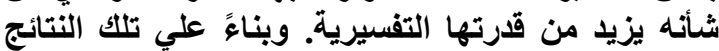

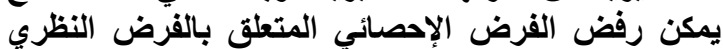

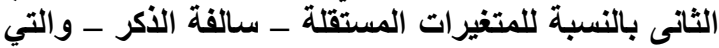

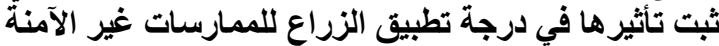
في مجالي الإنتاج الحيواني والداجني.

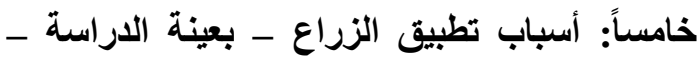

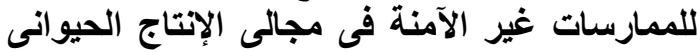

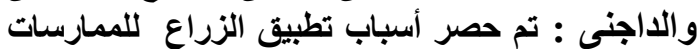

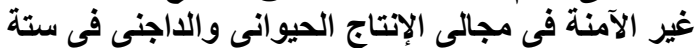

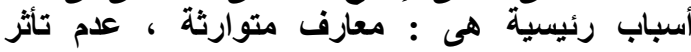

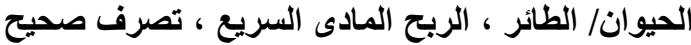
فى رأى، هذا ما يفعلة عموم الناس ، لا يوجد بديل الخر الخر. [1] [أسباب تطبيق الزراع - بعينة الدراسة ـ للممارسات

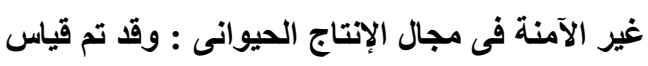
هذه الأسباب من خلال قسمة الرقم الذى حصل عليه كل سبب من الستة أسباب الخاصة بتطبيق الممارسة غير الأمنة فى مجال الانتاج الحيوانى على المجموع
[2] [الهمية النسبية للمتغيرات المستقلة المدروسة في تفسير التباين الحسادث في درجـة تطبيق الزراع بعينة الاراسـة ـ بالممارسـات غير الآمنـة في مجالي

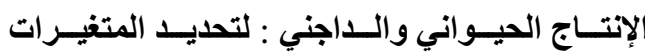
المستقلة المؤئرة في درجة تطبيق الزراع - بعينة الاراسةـ بالممارسات غير الآمنة في مجالي الإنتاج

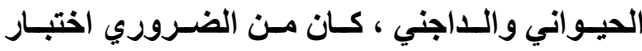
الفرض النظري الأول والذي تـم اختبـاره بـالفرض الإحصـائي التـالي : لا تتـأثر درجـة تطبيـق الـزراع بالممارسات غير الآمنة في مجالي الإنتاج الحيواني والداجني (كمتغير تابع ) بكل من المتغيرات المستقلة المدروسـة ، واسـتخدام نمـوذج التحليـل الاتحــاري المتعدد المتدرج الصـاعد "Step wise" هذا فيمـا

$$
\text { يختص بـالمتغيرات التـي قيسـت بمقيساس فتـري }
$$
"Interval Variables"

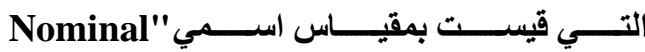
Variables لتقدير تأثير تلك المتغيرات. (Eta²)

وتثير النتائج الواردة بجدول (11) إلى معنوية نموذج التحليل الانحداري المتعدد المتـرج الصـاعد حتى الخطوة

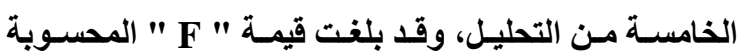
10,270 وهى معنوية على المستوى الاحتمالي 0.01 ، وهذا يعنى أن هنـاك خمسـة متغيرات مستقلة ـ فتريـة ـ تؤثر في درجـة تطبيق الزراع بالممارسـات غير الآمنـة في مجـالي الإنتاج الحيو اني والداجني ، ولقد بلغت قيمـة معامل الارتبـاط

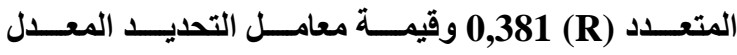
قد بلغت 0,132, ممـا يعنى أن المتغيرات (Adjusted R²) 
كل سبب من الستة أسباب الخاصة بتطبيق الممارسة غير الأمنة فى مجال الانتاج الداجنى على المجموع

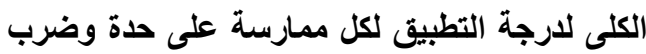
ناتج القسمة فى مائة ، ولمعرفة الوزن النسبى لكل لكل

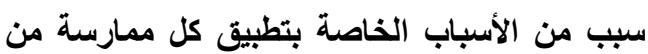

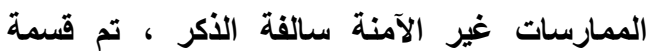

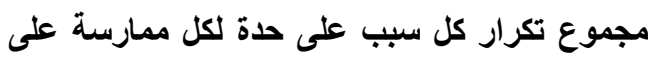
المجموع الكلى لتكرارات الست أسباب وضرب الناتج فى مائة ، كما توضحها النتائج الواردة بجدول (13) ومنها يتبين أن أكثر ثلاثة أسباب فى تطبيق الزراع

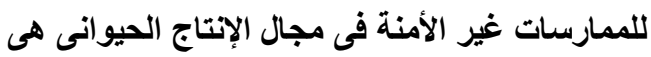
على الترتيب : تصرف صحيح فى رأى (43.9\%) ،

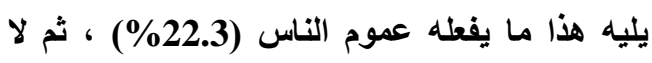
يوجد بديل أخر (16.6\%).
الكلى لدرجة التطبيق لكل ممارسة على حدة وضرب ناتج القسمة فى مائة ، ولمعرفة الوزن النسبى لكل سبب من الأسباب الخاصة بتطبيق كل ممارسة من الممارسات غير الآمنة سالفة الذكر ، تم قسمة مجموع تكرار كل سبب على حدة لكل ممارسة على المجموع الكلى لتكرارات الست أسباب وضرب الناتج فى مائة ، كما توضحها النتائج الواردة بجدول (12) ومنها يتبين أن أكثر ثلاثة أسباب فى تطبيق الزراع

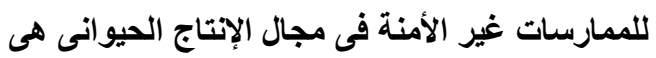
على الترتيب : تصرف صحيح فى رأى (38.9\%) ،

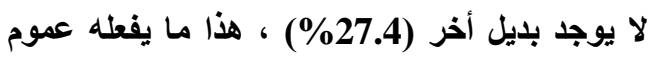
الناس (24.4\%) .

[2] [أسباب تطبيق الزراع - بعينة الاراسة ـ للممارسات

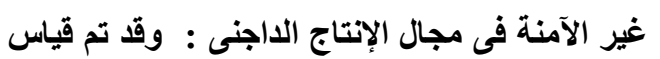
هذه الأسباب من خلال قسمة الرقم الذى حصل عليه

جدول رقم 11. نتائج التحليل الانحاري المتعدد المتدرج الصاعد Step-wise لتحديد الأهمية النسبية للمتغيرات المستقلة الفترية المؤثرة في درجة تطبيق الزراع - بعينة الدراسة - بالممارسات غير الآمنة في مجالي الإنتاج

\begin{tabular}{|c|c|c|c|c|c|c|}
\hline قيمة معنة لاختة معامل & 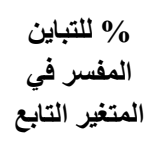 & $\begin{array}{c}\text { معامل التحديد } \\
\text { \# المعدل } \\
\text { (Adjusted R²) }\end{array}$ & $\begin{array}{l}\text { التحديدل } \\
\text { معامل } \\
\left(\mathbf{R}^{2}\right)\end{array}$ & | معامل الارتباط & المؤثرة في المتغير التابع & خطوات \\
\hline$* * 27,935$ & $\% 7.3$ & 0.073 & 0.076 & 0.275 & درجة المعرفة بالممارسات غير الآمنة & الخطوة الأولى \\
\hline$* * 18,696$ & $\% 2.7$ & 0.100 & 0.106 & 0.326 & بالإنتاج الحيو انى والإجنى المبحث & الخطوة الثانية \\
\hline$* * 14,387$ & $\% 1.2$ & 0.112 & 0.121 & 0.348 & الإتجاه البيئى & الخطوة الثالثة \\
\hline$* * 12,615$ & $\% 1.1$ & 0.123 & 0.134 & 0.366 & الرضا المجتمعى المحلى & الخطوة الزابعة \\
\hline$* * 10.270$ & $\% 0.9$ & 0.132 & 0.145 & 0.381 & مستوى تعليم أسرة المبحوث & ل لخطوة الخامسة \\
\hline
\end{tabular}


Unsafe practices in animals and poultry production in rural areas of Menuofia ...

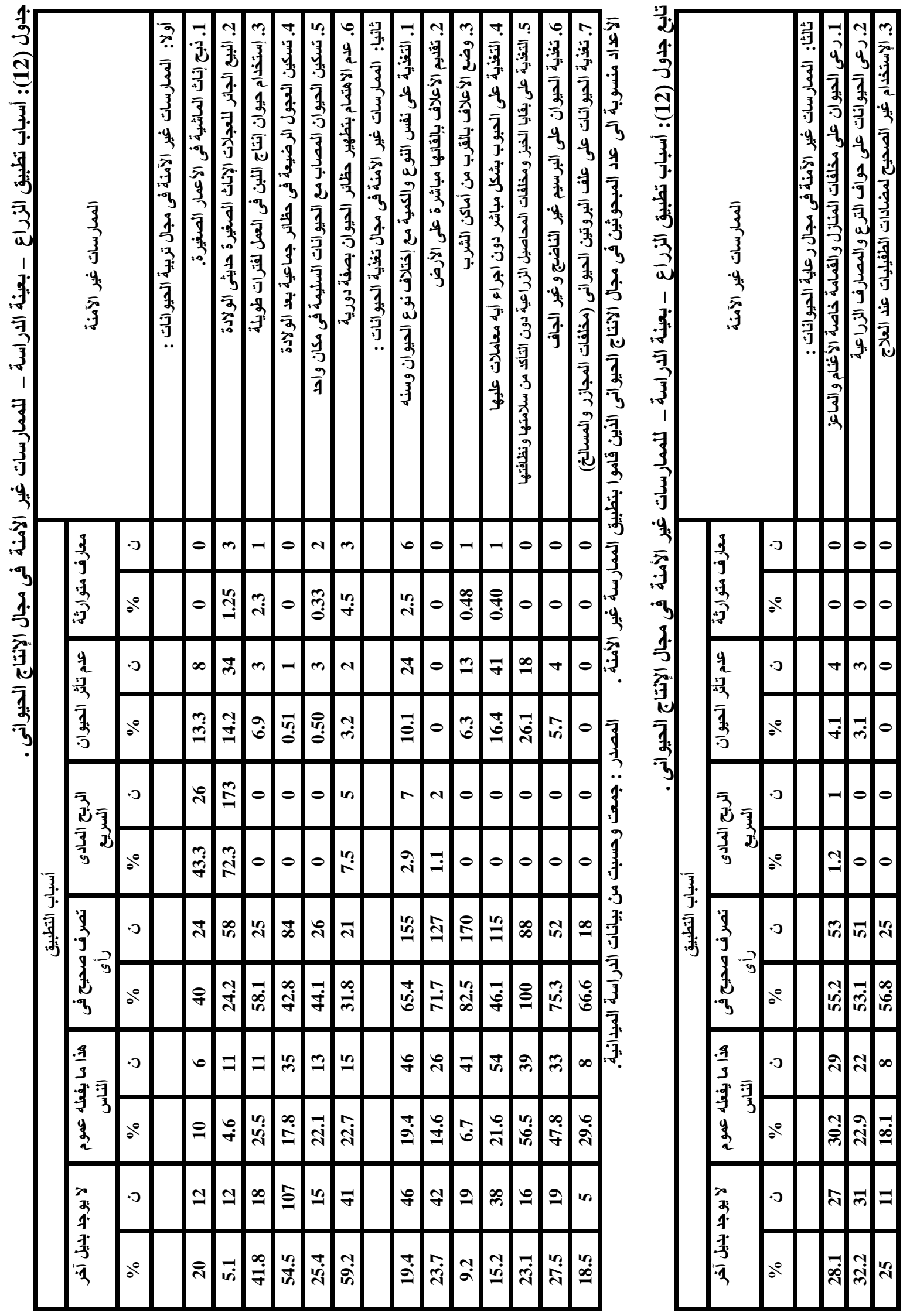


Unsafe practices in animals and poultry production in rural areas of Menuofia ...

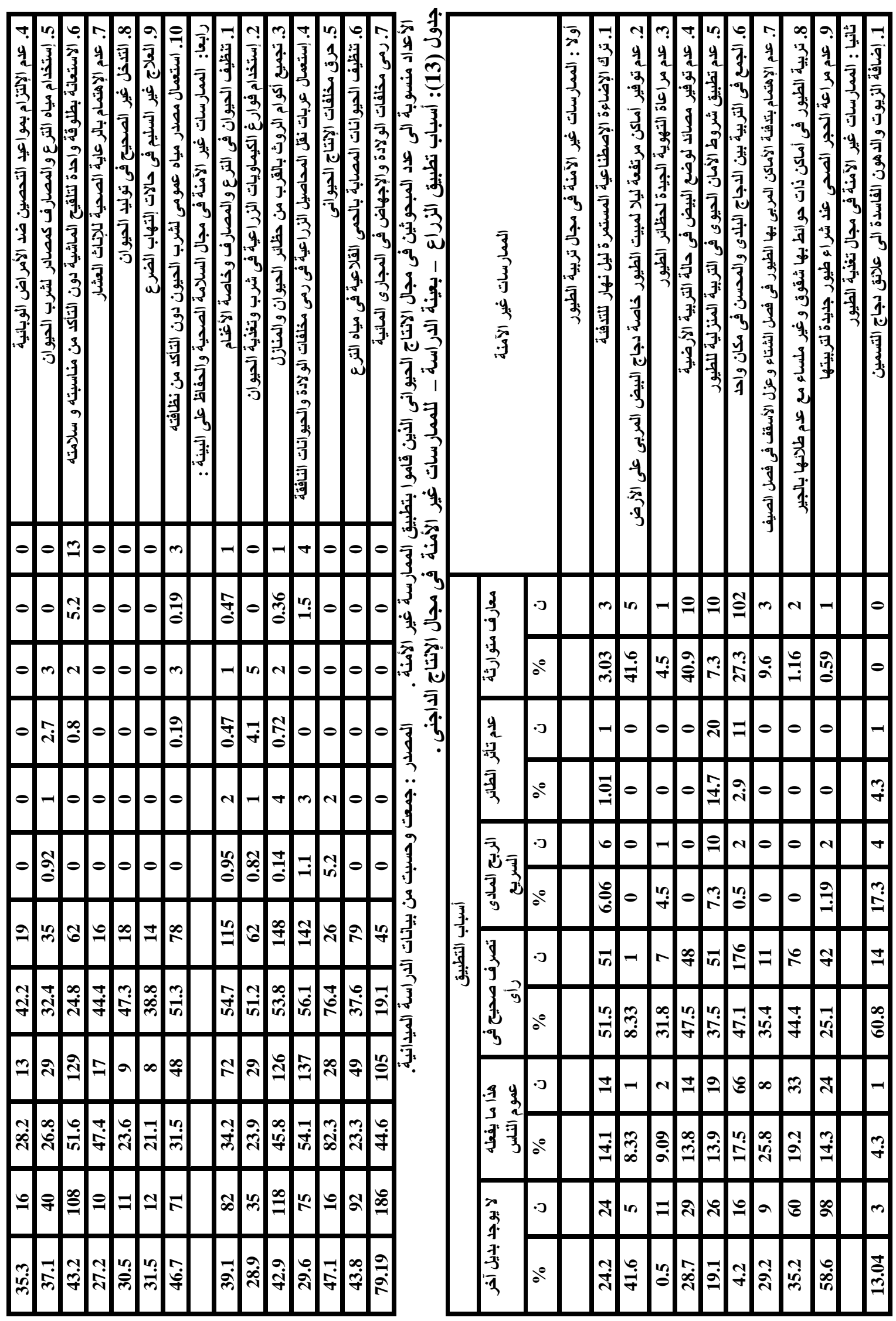


F.A. Salama, et al.,

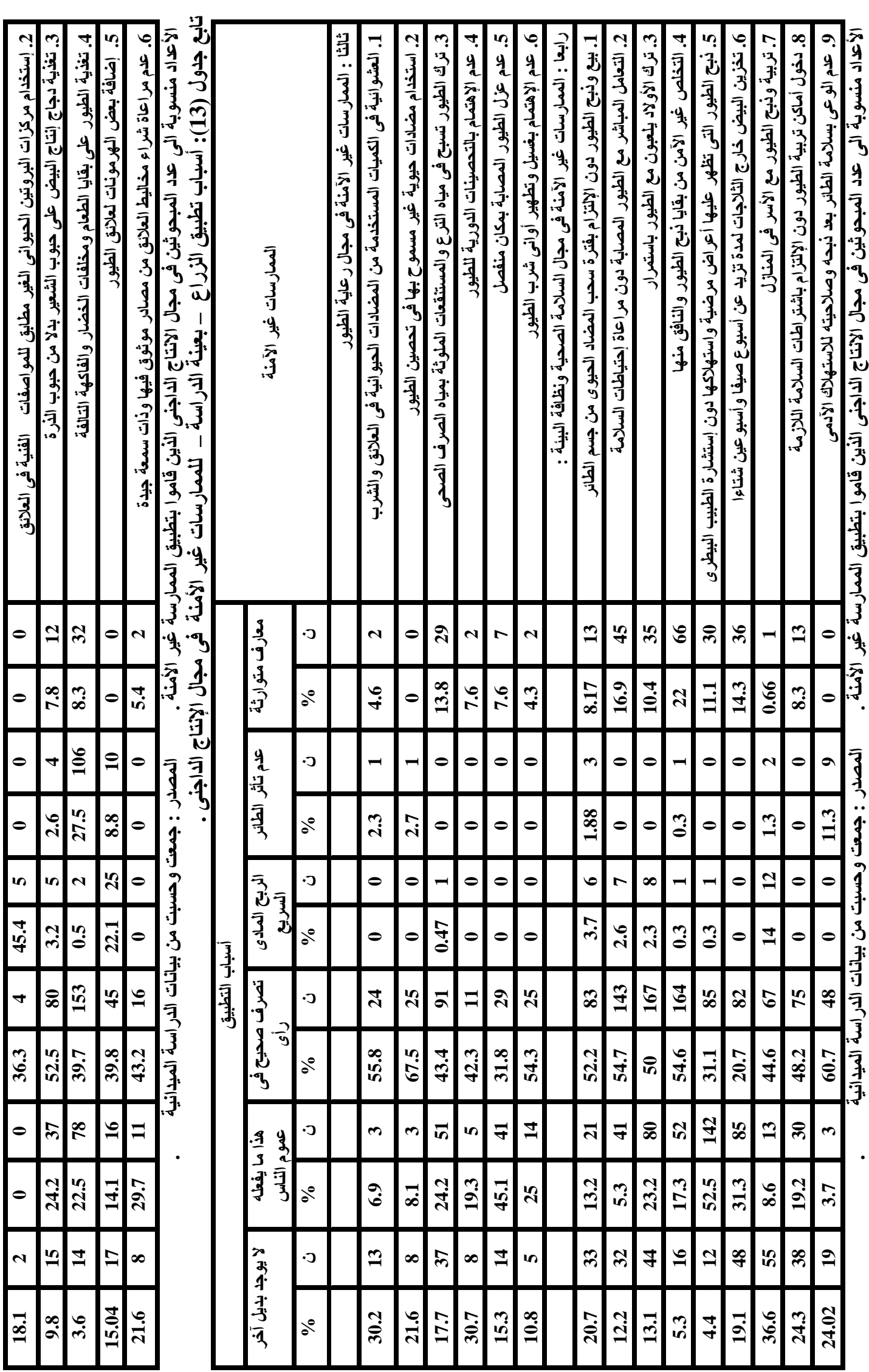


الزراع بالأمراض المشتركة بين الإنسان والحيوان

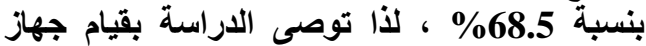
الإرشاد الزراعى والبيطرى لتنفيذ توضيذ حملات بيطرية مكئفة للوقاية من هذه الأمراض الوبائيائية والتى تثثكل

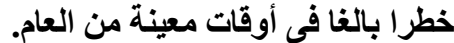

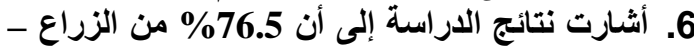

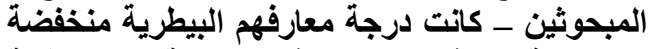

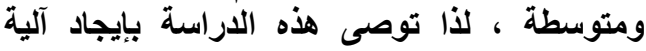
للتنسيق بين الجهاز الإرشادي البيطري والبرائة والمنظمات الزراعية والتعليمية و والإجتماعية والإيطية والإعلامية وشركات الأدوية والمبيدات البيطرية والألماتية والأعلاف

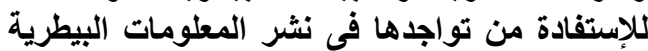

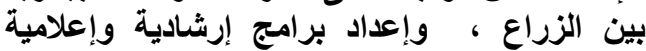
مناسبة لاى حائزى الحيوانات المزرعية والطيور والثية

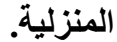

7. أوضحت نتائج الدراسة أن أكثر أسباب تطبيق الزراع

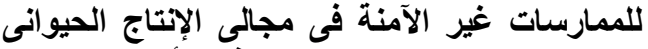

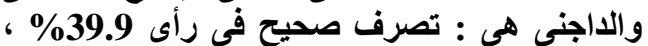

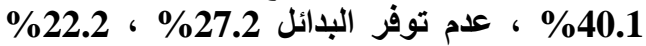
على الترتيب ، مما يعنى عجز أو ضعف التف الأجزان

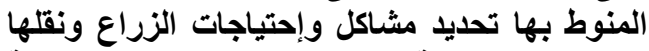
إلى الجهات البحثية لدراستها وإيجاد الحلول الجئات المناسبة

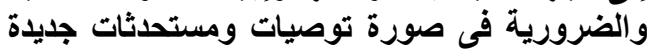

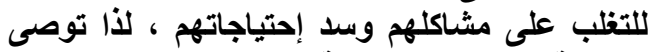

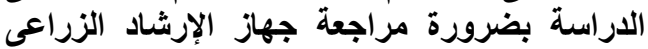

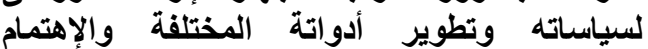
بالمشاكل الفعلية والملحة للزراع في هذا لفئل القطاع الهام و الحيوى.

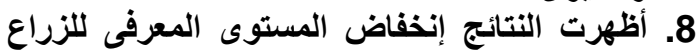

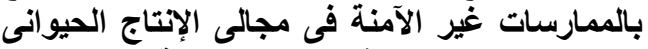

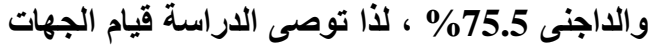

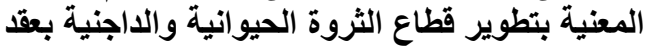

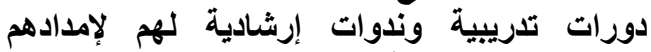

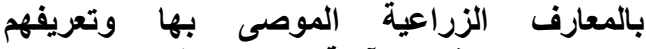

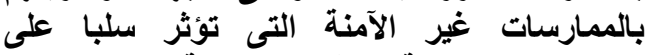
الحيوانات المزرعية والطيور المنزلية التى بحوزتهرج

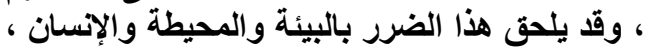

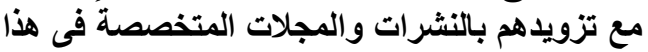

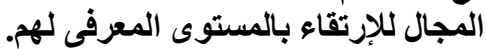

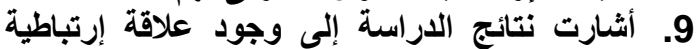
موجبة بين درجة معرفة الزراع باع بالممارسات غيرة غيرة

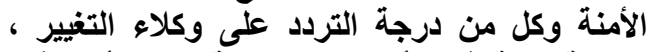
ودرجة الثقة فى الأجهزة الحكومية ، كما النية أن هذين الثين

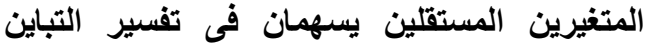

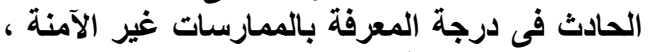

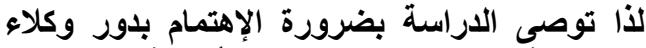

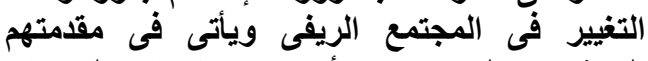
المرشدين الزراعيين وأخصائى الإنتاج الحيو فئنى والداجنى ، والذين لهم دور هام فى تقلين الثيل الفجوة

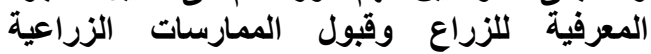

\section{التوصيات: - (التوء}

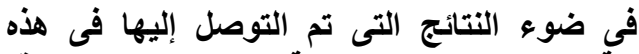

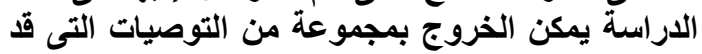

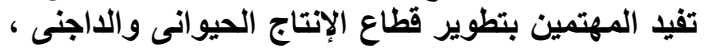

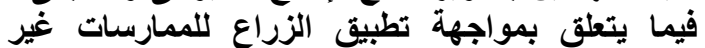
الآمنة فى هذا القطاع ، ويمكن ذكرها في النقاط النقاط التالية :

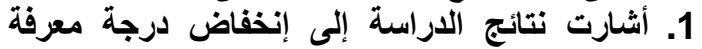
الزراع بالتوصيات الفنية فى مجال الإنتاج الحيوانى،

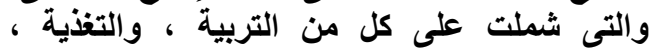
والرعاية ، والسلامة الصحية والتئية والحفاظ على البيئة

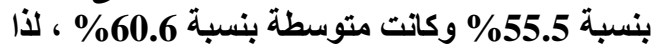

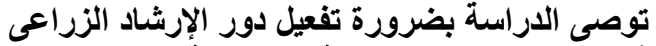

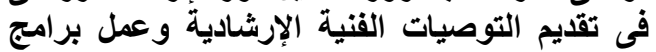
تدريبية بالتعاون والتنسيق مع جهاز الإرشاد البيطرى برئ وخاصة فيما يتطلق بطرق التربية التربية الصحيحة

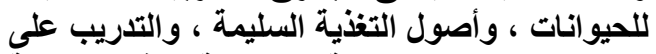

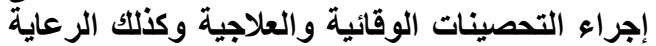
البيطرية والتتاسلية لقطعان الثروة الحيوانية النية.

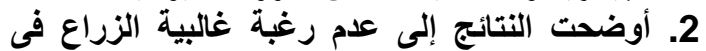

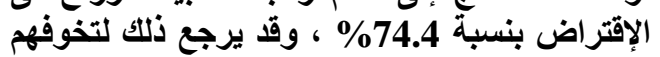

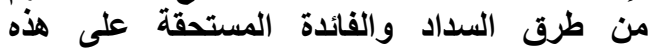
القروض أو يعزى إلى تخوفهم من الفشل وعدم نجاح التهاح

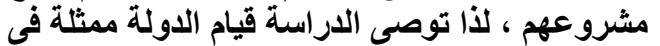

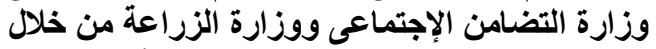

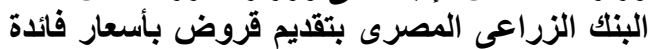

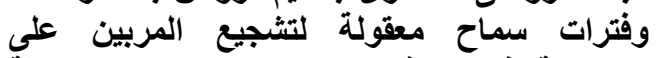

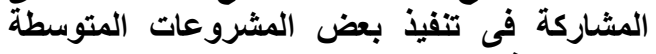

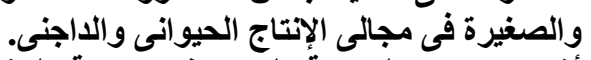

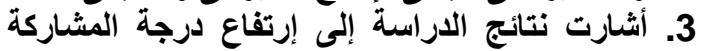

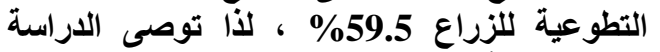

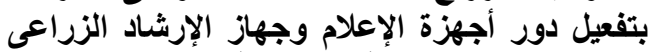

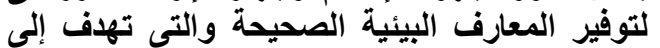

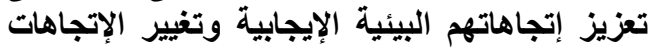

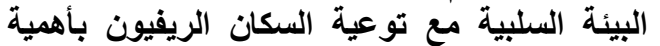
المشاركة في البرامج والمشروعات البرات التنموية التئي تهوف لحماية وصيانة الأنظمة البيئة وإستدامة الموارد الطبيعية. 4. أظهرت النتائج أن غالبية المبحوثين 95.2\% بوارئة يرون

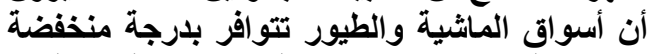

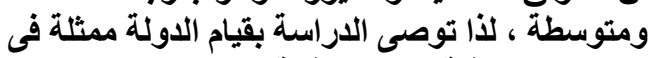

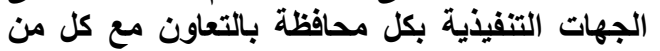

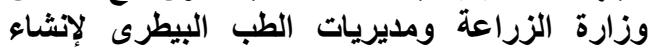
مراكز تسويقية لمدخلات ومخرجات الثرات الثرة الحيوانية النياء

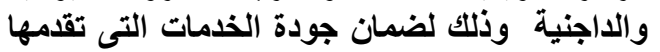
هذه المراكز التسويقية مع تطبيق إحتياطات الآمان الحيوى والسلامة الصحية بها لمنع إنتثار الأمراض الاضن و الأوبئة. 5. أشارت نتائج الدراسة إلى إرتفاع مستوى تعليم

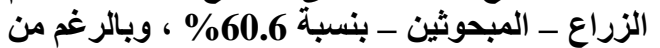
ذلك أوضحت النتائج أيضاً إنخفاض درجة معرفة دمن 
8. الوهاب (2012) : إدراك المرأة الريفية لأهمية مزايا ومشكلات تربية الأغنام والماعز وعلاقتة

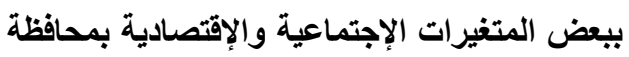

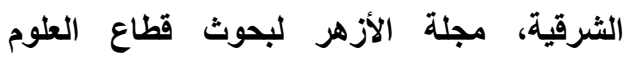

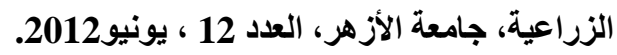

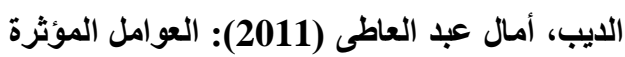
على اتجاه ومشاركة الريفيات فى أنشطة التربية

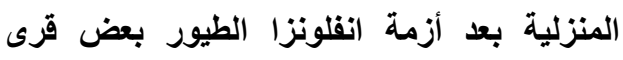

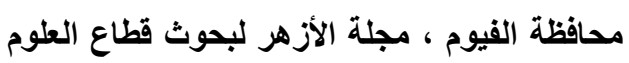

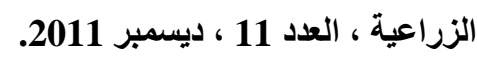
10. الديب، شيرين محمود حمدى (2016): الإحتياجات الزئ الإرشادية المعرفية فى مجال إنتاج لبن نظيف وآمن الإحن

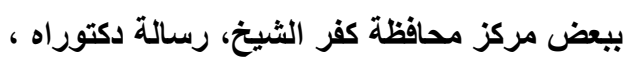

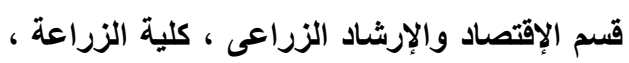
جامعة كفر الثيخ. 11. الخولى ، شيماء عبد المجيد عبد الله (2015) :

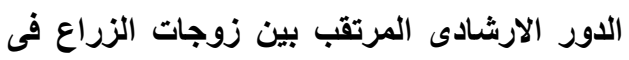

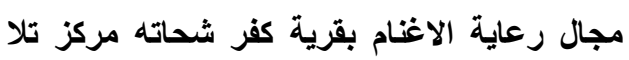
محافظة المنوفية ، رسالة دكتوراة ، كلية الزراعة، كائه جامعة الاسكندرية . 12. العباسى، صيام عبد الغفور، أحمد عبد الوارث على،

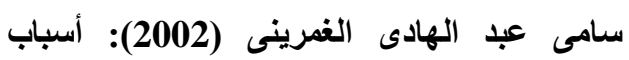
عزوف الريفيات بيعض قرى محافظة الفيوم عن تبنى الاجاج المحسن، الجمعية الاحصائية المصرية،

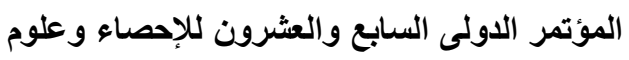
الحاسب وتطبيقاته 13- 18 إبريل.

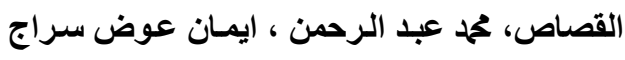

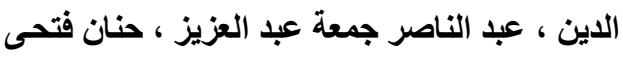

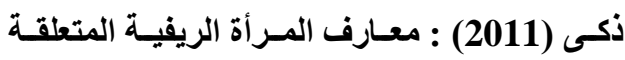

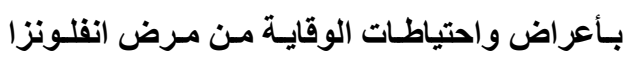
الطيور فى قريتين بمحافظتى البحيرة والأسكندرية ، مجلة الجديد فى البحوث الزراعية ، المجلد 16 ،

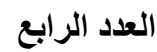
14. الغنام ، عادل فهمى ( 2001) : الوعى والسلوك الوك

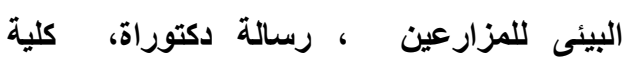
الزراعة، جامعة الاسكندرية .
الموصى بها ، جنبا إلى جنب مع تفعيل دور الأجهزة

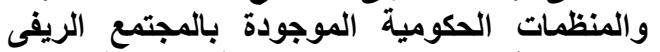
والتى من أهمها الجمعيات التعاونية الزراعية وجهاز الرئية الإرشاد البيطرى.

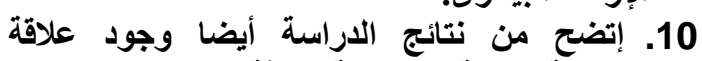
إرتباطية موجبة بين درجة معرفة الزئة الزراع بالممارسات

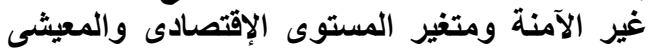

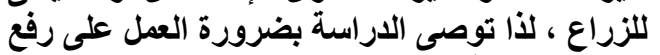

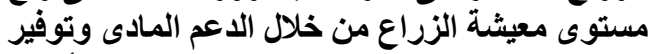

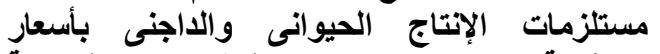
منخفضة ، مع توجيه بعض الإنتاج المشروعات المغات التموية

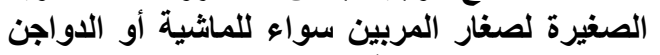

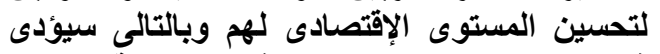

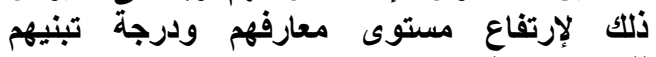
للممارسات الموصى بها.

المراجع

1. أبو حطب، رضا عبد الخالق مأمون (1978): دراسة الإسة

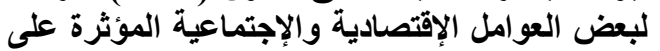

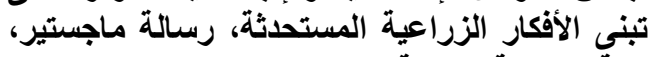

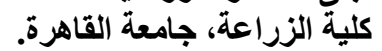
2. أبو السعود، خيرى حسن (1987): الارشاد الزراعي الزئي "التنظيم والتخطيط والتقويم" ، مديرية الارية التربية والتعليم، الجمهورية العربية اليمنية .

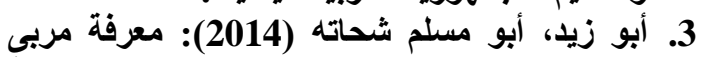

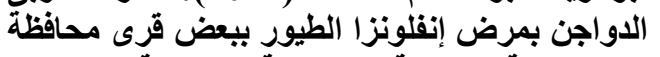

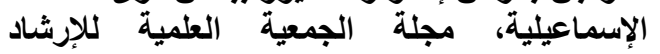
4الزراعى، المجلد الثامن عشر، الجية، العدد الثالث.

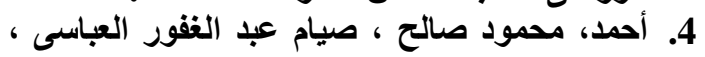

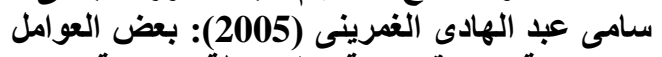

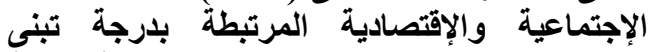

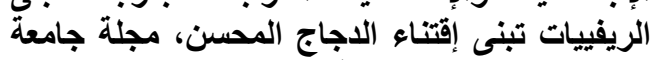

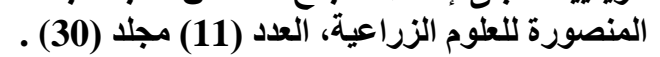
5.

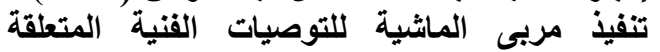

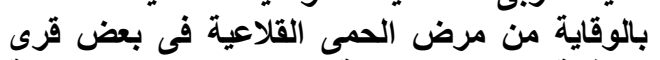

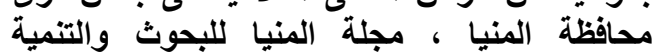

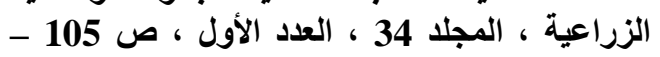

6. الديب ، هدى أحمد أحمد علدوان (2002) ، دراسـة

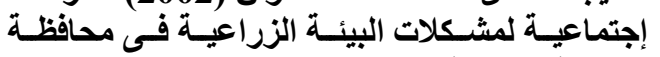

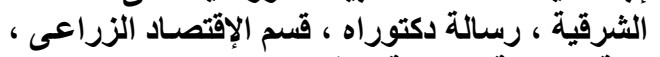

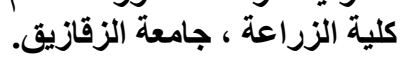
7. الديب، أمال عبد العاطى، نادية نبيل ذكى (2012):

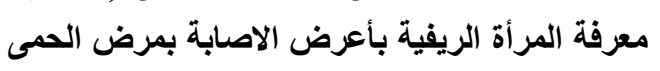
القلاعية فى الماثية وتنفيذها إحتياطات الوقاية منها،

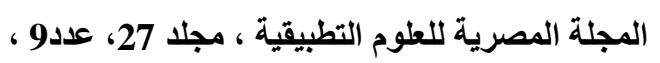

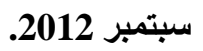


F.A. Salama, et al.,

على انتشار بعض الأفكار التكنولوجية بمنطقة

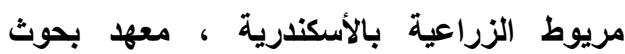
الارشاد الزراعى والتنمية الريفية ، مركز البحوث بالئريه

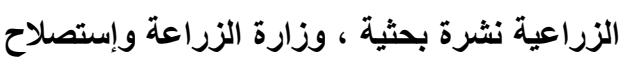
الأراضى ، رقم 179 ـ 179 24. جمعه، أمل تحم، سحر عبد الخالق هيكل، إبراهيم

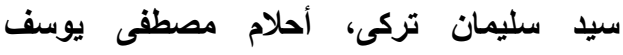
(2013): تطبيق الريفيات لتوصيات الفنية الموصى بها فى مجال إنتاج الألبان بمركزين بمحافظة القليوبية، مجلة الجمعية العلمية للإرشاد الزراعى ، المجلا السابع عشر، العدد الثالث. 25. رمضان، عبدالله عبدالفتاح (2012): تحديد مرتقبات العمل البيطرى لمربى الماشية ببعض قرى منطقة البستان باقليم غرب النوبارية، مجله لئل الاسكندريةللبحوث الزراعية، مجلا 57، العدد الثالث.

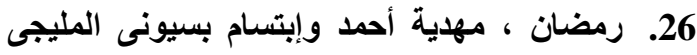
(2015): سلوك الريفيات فى مجال التربية الأمنة للطيور المنزلية بمحافظة كفر الثيخ ، المجلة المصريةللابحوث الزراعية، المجلد 93، العدد الثالث. 27. رمضان، مهدية أحمد (2007): المستوى المعرفى والمهارى للريفيات فى بعض مجالات الإقتصاد المنزلى بمركز كفر الثيخ، رسالة دكتوراة ، كلية الزراعة ، جامعة كفر الثيخ.

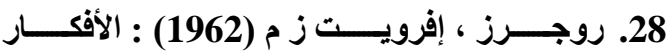

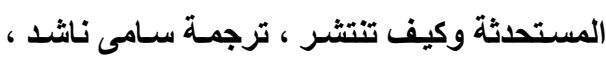
عالم الكتب ، القاهرة. 29. عبد الغفـار ، عبد الغفــار طـه (1976) : الارشــاد الزراعى بين الفلسفة والتطبيق ، دار المطبوعات الجديدة ، الأسكندرية.

30. عبد الرحمن ، طارق عطية ، لمياء سعد الحسينى الجنى (2012): محدات السلوك البيئى المسئول

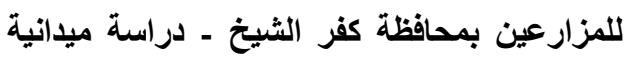

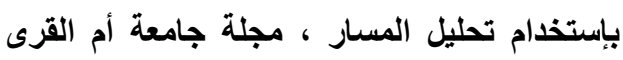

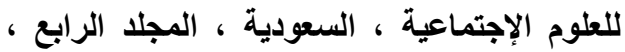

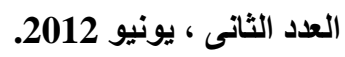

15. المليجى ، إبتسام بسيونى (2012): معارف مربى ماثية اللبن ببعض الأمراض التى تصيب الماثية والمتغيرات المؤثرة عليها فى بعض قرى محافظة كفر الثيخ ، مجلة الجمعية العلمية للإرشاد الزراعى، المجلد السادس عشر، العدد الرابع.

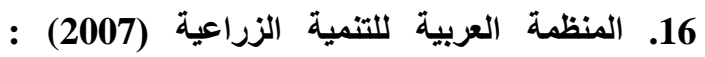
أوضاع الامن الغذائى العربى ، جامعة الدول العربية

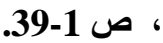
17. بالانت ، جولي (2007): التحليل الإحصائي باستخدام برامج SPSS ، ترجمة خالد العامري، الطبعة الأولي، دار الفاروق للنشر والتوزيع، تردي،

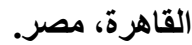
18. بطرس ، سـناء شـحاته (2009) : تطبيـق المـرأة الريفية لتوصيات التربية المنزلية الأمنه لمواجهة مرض انفلونزا الطيور بقريتين بمحافظة الفيوم ،

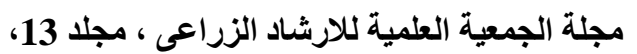

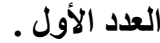
تقرير التتمية البشرية لمحافظة المنوفية (2014): مؤثــرات التتميـة البثــرية لمحافظــة المنوفيـة، مؤشـرات قرى ومـدن ومراكز محافظة المنوفيـة، معهل التخطيط القومى بالتعاون مع وزارة التتمية المحلية، القاهرة، جمهورية مصر العربية، 2015. 20. حسن، نهى الزاهى (2016): المشكلات التى تواجه الريفيات فى إنتاج لبن نظيف وآمن بمحافظة كفر الثيخ، مجلة البحوث الزراعية ــ العلوم الإقتصادية والإجتماعية الزراعية ، جامعة كفر الثيخ ، العدد الزئد

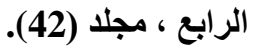

21. حسن ، عبد الباسط تحمل (1998) : أصول البحث الاجتماعى ، الطبعة الثانية عثر ، مكتبة وهبة ،

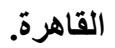
22. حننين، مجدى أنور (2012): معارف وممارسات مربى الماشية بمحافظة الاسماعيلية فى مجال الامراض المشتركة بين الانسان والحيوان، مجلة

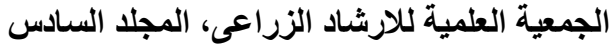
عشر، العدد الأول 2012. 23. جاد الرب ، محم عبد الوهاب ، محم يوسف شلبى الأب (1997) : دراسة خصائص مربى الماشية المؤثرة 
بحثية رقم 95 ، معهز بحوث الارشاد الزراعى ، بحثي والتنمية الريفية ، مركز البحوث الزراعية ، وزارة

$$
\text { الزراعة , مصر. }
$$

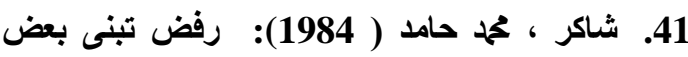

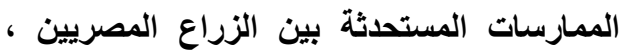

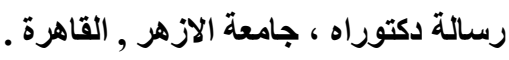
42. شلبى ، محمد يوسف أحمد ، محمود رجب تركى ، رئل

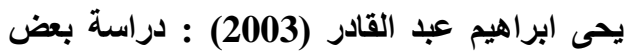
المتغيرات المؤثرة على معارف مربى عجول

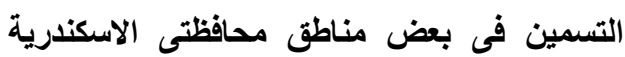

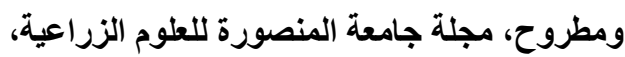
مجلد 28 ، العدد (9) سبتمبر 2003. 43. شلبى ، أسماء يوسف (2016) ، العاد (9) : معرفة مربى

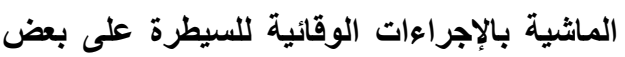
الأمراض المعدية فى الماثية بمحافظة كفر الثيخ،

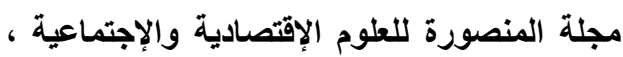

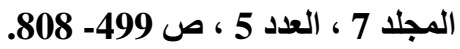
44. قتيبر ، خالد عبد الفتاح على (2011) : مستوى العال المعارف والسلوك البيئى للمرأة الريفية دراسة بريف محافظة المنوفية، مجلة المنصورة للعلوم

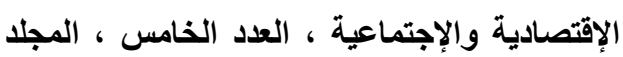

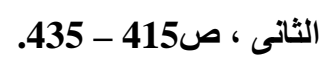
45. موسى ، سامية عبد الرحمن ، مارى بـ بشرى

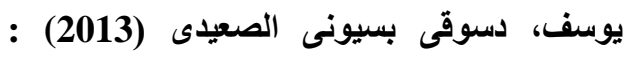
معارف ومصادر أخصائيو الانتاج الحيوانى بمرض لئن

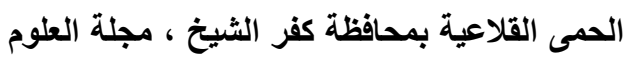

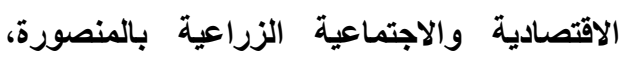
مجلد 4 العدد 11، نوفمبر 2013.

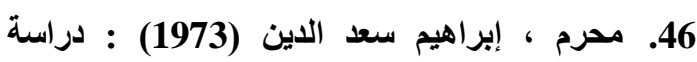

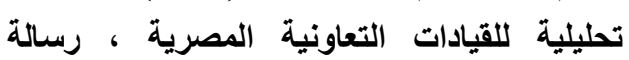
دكتوراه ، كلية الزراعة ، جامعة عين شمس. 47. محم ، زينب على (1996) : إستخدام الريفيات

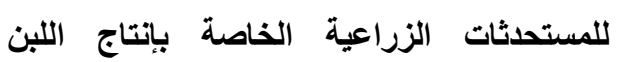
والعوامل المؤثرة عليه بقرى محافظة مركز

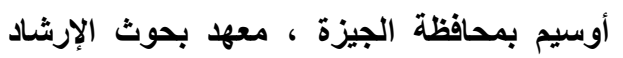

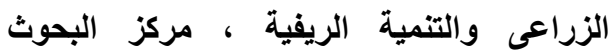

31. عبد المقصود، بهجت محم (1988): الإرشاد الزراعى، دار الوفا للطباعة والنشر والتوزيع، الإنياء

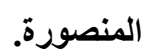
32. عثمان، إيمان ماهر محمود (2009) : تبنى المرأة الريفية لللممارسات البيئية بمحافظة المنوفية، رسالة ماجستير، كلية الزراعة، جامعة المنوفية . لإنة

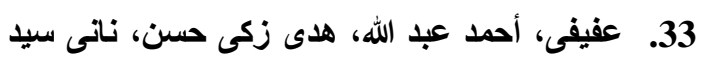

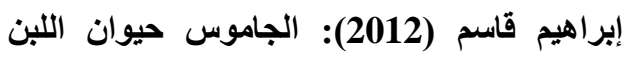

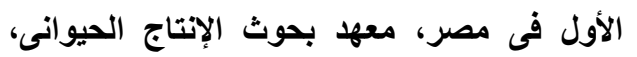
مركز البحوث الزراعية، نثرة فنية رقم 19.

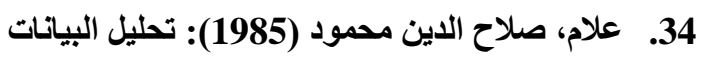

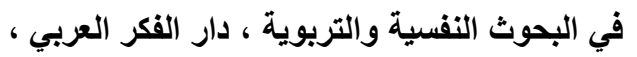

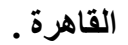

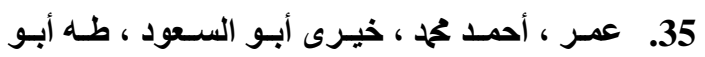

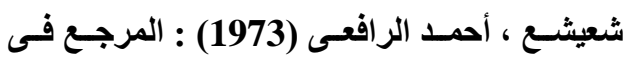
الإرشاد الزراعى ، دار النهضة الرافئ العربية.

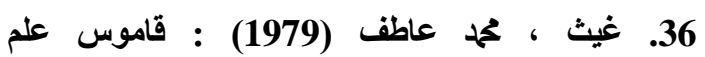
الإجتماع، الهيئة المصرية العامة للكتاب، القاهرة.

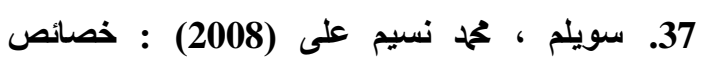

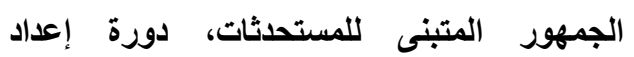

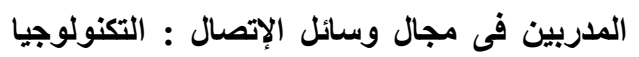

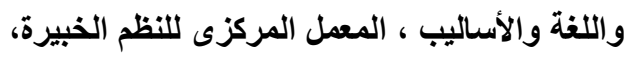

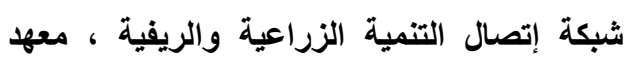
بحوث الإرشاد الزراعى والتنمية الريفية ، مركز الرية ، معثي

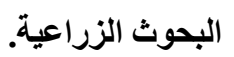

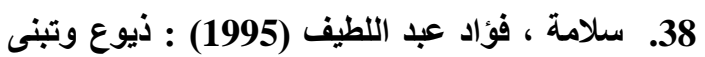

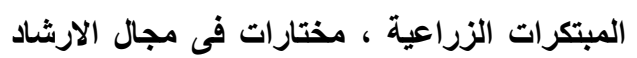

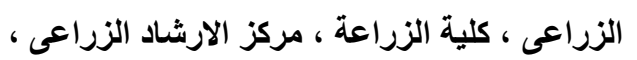
جامعة الملك سعود ، المملكة العربية السعودية.

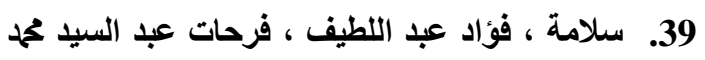
(2011) : تحليل مسارى لمحددات السلوك البيئى فئل للسكان الريفيين بمركز منوف فى محافظة المنوفية

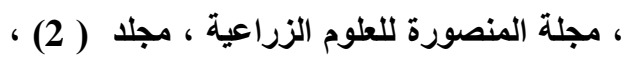

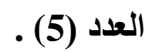

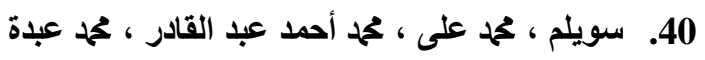

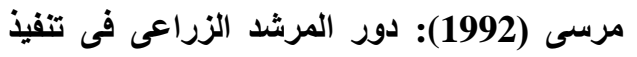

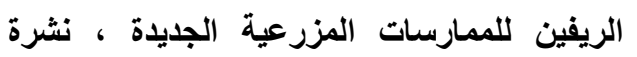


F.A. Salama, et al.,

Edition, International Student Edition, McGraw-Hill Book Comping.

53.Pannell, David J., et al. "Understanding and promoting adoption of conservation practiceby rural landholders." Australian journal of experimental agriculture 46.11 (2006): 1407-1424.

54.Rogers, E.M. (1983)." Diffusion of Innovation", The Free Press, New York,USA.

55.Rogers, E.M. (1995)." Diffusion of Innovation", The Free Press, New York,USA.

56.Rogers, E. M. (2003) - "Diffusion of innovations" (5th edition). New York, NY: Free Press.

57.Salama ,Fouad Abdel - Latif (1993) ," Acousal model of integrated pest Management Adoption Amiong Farmers" . Ph Disescration, lowa StateUniversity, Ames ,IOWA.
الزراعية ، وزارة الزراعة ، نثرة بحثية رقم .171

48. محم ، فرحات عبد السيد (1995) : دراسة تقييمية

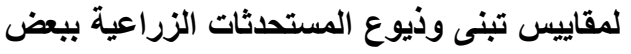

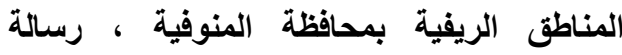
ماجستير ، كلية الزراعة ، جامعة المنوفية.

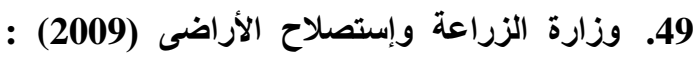

كتيبات عن مختلف الأمراض الوبائية، تقرير فنى، الهيئة العامة للخدمات البيطرية.

50. منظمة الأغذية والزراعة للأمم المتحدة (2012):

$$
\text { المضادات الحيوية والصحة الحيوانية : }
$$

www.fao.org/home/ar/(14/4/2016, 10.pm)

51. Mosher ,(1978). " An Introduction To Agricultural Extension. Agricultural Development Council". Lowly. New York.

52.Pindyck, Robert S. and Daniel L. Rubinfeld (1981), Econometric Models and Economic Forecasts, Second

\title{
UNSAFE PRACTICES IN ANIMALS AND POULTRY PRODUCTION IN RURAL AREAS OF MENOUFIA GOVERNORATE
}

\author{
F.A. Salama, F. A. Mohamed, K. A. Ali and S. A. Abdel-Samad \\ Department of Agricultural Extension and Rural Sociology College of Agriculture, Menoufia., \\ University, Shebin El-Kom, Egypt
}

\begin{abstract}
This study aimed basically at identifying the level of adoption of unsafe practices in animals and poultry Production in rural areas of Menoufia governorate, This main objective was achieved theoretically and empirically through the following subobjectives: Identifying the knowledge level of unsafe practices by growers in animals and poultry Production. Determining the correlates of the unsafe practices knowledge level, Identifying the application degree of unsafe practices by growers in animal and poultry Production, Determining the correlates of the unsafe practices application degree, Identifying the reasons of applying the unsafe practices by growers in animals and poultry Production.
\end{abstract}

The study was carried out in four villages in Menoufia governorate, the first village was Sahel El gawaber, the second village was El erakya, the third village was Abo koles and Kafer deneshway of El shohadaa district. A sample of 318 growers in animal and poultry Production. was selected randomly from the four villages. A questionnaire was used to collect the data from the respondents through personal interviews, the data were analyzed descriptively and analytically by using frequencies, percentages, range, variance, reliability estimate, simple correlation, step- wise multiple regression.

The study findings can be summarized as follows :The knowledge degree of unsafe practices was low as $75.5 \%$ from all respondents by growers in animals and poultry 
F.A. Salama, et al.,

Production, The applying degree of unsafe practices was middle and high as $81.3 \%$ from all respondents by growers in animal and poultry Production, There were significant positive relationships at the level 0.01 between each of the level of respondent education, The knowledge of the respondent related to animal and poultry production, frequency of visiting change agents, environmental attitude, degree of geographical and cultural openness, average of respondent education, The trend towards innovation of animal and poultry production, The degree of confidence in government agencies, frequency of visiting of service centers, Average Family Education, Monthly income of the respondent, as independent variables and the knowledge degree of unsafe practices as a dependent variable, There were significant positive relationships at the level 0.05 between each of, Degree of availability of animal and poultry production requirements, The economic and living level of the respondents, as independent variables and the knowledge degree of unsafe practices as a dependent variable, There were four independent variables (The knowledge of the respondent related to animal and poultry production, frequency of visiting change agents, , environmental attitude, The degree of confidence in government agencie) explained together $24 \%$ of the total variance of the knowledge degree of unsafe practices, There were significant negative relationships at the level 0.01 between each of the knowledge degree of unsafe practices, as independent variables and the application degree of unsafe practices as a dependent variable, There were significant positive relationships at the level 0.05 between each of, Functional experience of the respondent, as independent variables and the application degree of unsafe practices as a dependent variable, There were significant negative relationships at the level 0.01 between each of the knowledge of the respondent related to animal and poultry production, environmental attitude, average of respondent education, average of family education, as independent variables and the application degree of unsafe practices as a dependent variable, There were significant negative relationships at the level 0.05 between each of, frequency of visiting change agents, frequency of visiting service centers, as independent variables and the application degree of unsafe practices as a dependent variable, There were five independent variables (the knowledge degree of unsafe practices as a dependent variable, the knowledge of the respondent related to animal and poultry production, environmental attitude, Local community satisfaction, Average Family Education) explained together $13 \%$ of the total variance of the application degree of unsafe practices as a dependent variable.

Key words: Unsafe practices, animals and poultry production, rural areas of Menoufia governorate

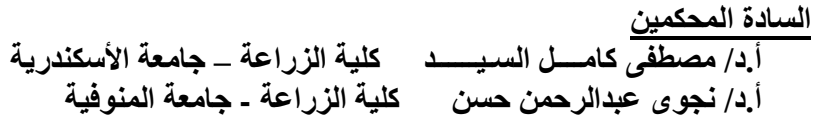

